\title{
ADDENDA AND CORRIGENDA TO THE CATALOGUE OF PALAEARCTIC COLEOPTERA, VOLUMES 7 AND 8 (CURCULIONOIDEA)
}

Miguel A. Alonso-Zarazaga ${ }^{1, \dagger}$, Roberto Caldara ${ }^{2}$, Antonio Machado ${ }^{3}$, Nicolas Maughan ${ }^{4}$, Jean Pelletier ${ }^{5}$, Helio Pierotti ${ }^{6}$, Li Ren $^{7}$, Alessandra Sforzi ${ }^{8}$, Hans Silfverberg ${ }^{9} \&$ Jirislav Skuhrovec $^{10}$

1Depto. de Biodiversidad y Biología Evolutiva, Museo Nacional de Ciencias Naturales (CSIC), c/. José Gutiérrez Abascal, 2, E-28006, Madrid, Spain. E-mail: zarazaga@mncn.csic.es

2Via Lorenteggio 37, Milan, I-20146, Italy. E-mail: roberto.caldara@gmail.com

${ }^{3} \mathrm{C} /$. Chopin 1, E-38208 La Laguna, Tenerife, España. E-mail: antonio.machado@telefonica.net

“Université de Provence, case 18, LATP, UMR CNRS 6632, Equipe "Evolution Biologique et Modelisation", 3 place Victor Hugo, F-13331 Marseille Cedex 3, France. E-mail: nicolas.maughan@etu.univ-provence.fr

55 Rue de la Saulaie, Monnaie, F-37380, France. E-mail: jzz.pelletier@wanadoo.fr

${ }^{6}$ Str Selvana 1, Treviso, I-31100, Italy. E-mail: peritelus@yahoo.it

${ }^{7}$ Key Laboratory of Zoological Systematics and Evolution, Institute of Zoology, Chinese Academy of Sciences,

No. 1 Beichen West Road, Chaoyang District, Beijing 100101, China. E-mail: renl@ioz.ac.cn

8Via dei Baglioni 5, I-51100 Pistoia, Italy. E-mail: alessandra.sforzi@libero.it

${ }^{9}$ University of Helsinki, Finnish Museum of Natural History, POB 17,

Helsinki, Fl-00014, Finland. E-mail: hans.silfverberg@helsinki.fi

${ }^{10}$ Group Function of Invertebrate and Plant Biodiversity in Agrosystems, Crop Research Institute, Drnovska 507, 16106 Praha 6 - Ruzyne, Czech Republic. E-mail: jirislavskuhrovec@gmail.com

${ }^{+}$Corresponding author. Authors are in alphabetical order.

\begin{abstract}
Additions, corrections, comments and nomenclatural novelties for the volumes 7 and 8 of the Catalogue of Palaearctic Coleoptera are provided. For the exact authorship of these check the text. One new species is described: Mecinus tavaresi Caldara \& Fogato, sp. nov. from Portugal and Spain. New synonymies are: Compsapoderus (Compsapoderus) erythropterus (Gmelin, 1790) = Attelabus intermedius Hellwig, 1795, syn. nov.; Paroplapoderus (Erycapoderus) angulipennis (Kolbe, 1886) = Paroplapoderus (Erycapoderus) angulipennis shaanxinsis Legalov, 2004, syn. nov. (Attelabidae); Aspidapion (Koestlinia) aeneum (Fabricius, $1775)$ = Aspidapion (Koestlinia) motschulskyi (Hochhuth, 1847), syn. nov., Taeniapion rufescens (Gyllenhal, 1833) = Taeniapion notatum (Wagner, 1912), syn. nov. (Apionidae); Larinus (Larinomesius) scolymi (Olivier, 1807) = Curculio teres Hellwig, 1795, syn. nov. (Curculionidae); Lixus paraplecticus (Linnaeus, 1758) = Curculio phellandrii Linnaeus, 1764, syn. nov. (Curculionidae); Curculio alternans Hellwig, 1795= Curculio alternans Herbst, 1795, syn. nov. (Curculionidae); Sibinia lyrata Faust, 1889= Sibinia attalica var. judea Pic, 1901, syn. nov. (Curculionidae); Phyllobius (Metaphyllobius) pomaceus Gyllenhal, 1834= Curculio prasinus Olivier, 1791, syn. nov. (Curculionidae). New homonymies are: Attelabus intermedius Hellwig, 1795 (non Attelabus intermedius Illiger, 1794); Baris marshalli Ramesha \& Ramamurthy, 2011 (non Baris marshalli Hustache, 1938). New replacement names are: Baris ramamurthyi Alonso-Zarazaga nom. nov. for Baris bimaculata Pajni \& Kohli, 1990 (non Hustache, 1932); Archarius (Archarius) kwonleeanus Alonso-Zarazaga nom. nov. for Archarius (Archarius) parvus (Kwon \& Lee, 1990) (non Archarius (Archarius) parvus (Hong \& Wang, 1987), a fossil species); Curculio (Curculio) zhangianus Alonso-Zarazaga nom. nov. for Curculio (Curculio) helleri Pelsue \& Zhang, 2002 (non Curculio (Curculio) helleri (Voss, 1932)); Lixus trichromus Alonso-Zarazaga nom. nov. for Lixus tricolor Capiomont, 1876 (non L. tricolor (Scopoli, 1771)). New combinations are: Cionus affinis (Brahm, 1790), comb. nov. from Curculio; Curculio helleri (Voss, 1932), comb. nov. from Balaninus; Donus diversisquamosus (Legalov, 2012), comb. nov. from Asiodonus; Donus knutelskyi (Legalov, 2012), comb. nov. from Asiodonus; Donus potanini (Legalov, 2012), comb. nov. from Asiodonus; Donus shokhrini (Legalov, 2012), comb. nov. from Asiodonus; Donus streltzovi (Legalov, 2012), comb. nov. from Asiodonus; Donus tshernyshevi (Legalov, 2012), comb. nov. from Asiodonus; Involvulus (Teretriorhynchites) icosandriae (Scopoli, 1763), comb. nov. from Curculio; Mecaspis alternans (Hellwig, 1795), comb. nov. from Curculio; Otiorhynchus mucronatus (Paykull, 1792), comb. nov. from Curculio; Pseudopoophagus constricticollis (Kojima \& Morimoto, 1993), comb. nov. from Apionodes. Protapion interjectum boreum (Gønget, 1997) is reconsidered as a valid subspecies based on
\end{abstract}


its genitalic characteristics, stat. res. The following names are declared nomina protecta under Art. 23.9.2 of the Code: Apion apricans Herbst, 1797 (now in Protapion) over Rhinomacer flavipes O.F. Müller, 1776 (nomen oblitum), Apion genistae Kirby, 1811 (now in Exapion) over Curculio astralagi Herbst, 1795 (nomen oblitum), Curculio piceus Pallas, 1771 (now in Sphenophorus) over Curculio piceus Wulfen in Scopoli, 1763 (nomen oblitum), Curculio phyllocola Herbst, 1795 (now in Anthonomus) over Curculio resinae Fabricius, 1792 (nomen oblitum), and Rhynchaenus posticus Gyllenhal, 1813 (now in Hypera) over Curculio denigratus Panzer, 1790 (nomen oblitum). Rhynchites laevior Faust, 1882 is confirmed as the type species of Aphlorhynchites Sawada, 1993 by a First Reviser action. Relevant dating for some works is provided. References have been completed and updated. Current misspellings have been corrected, amongst them, Hylesinus taranio Danthoine (not toranio).

\section{http://urn:Isid:zoobank.org:pub:BDD31261-3C09-48F2-97C4-FD3FF956CAFC}

Key words: Insecta; Coleoptera; Curculionoidea; Palaearctic Catalogue; additions; corrections; comments; dating; new synonyms; new homonyms; new replacement names; new combinations; type species confirmation.

\section{RESUMEN}

\section{Adiciones y Correcciones al Catálogo de Coleópteros Paleárticos, volúmenes 7 y 8 (Curculionoidea)}

Se presentan en este trabajo adiciones, correcciones, comentarios y novedades nomenclaturales que afectan a los volúmenes 7 y 8 del Catálogo de Coleópteros Paleárticos. Consúltese el texto para hallar la autoría exacta de cada una de ellas. Se describe una nueva especie: Mecinus tavaresi Caldara \& Fogato, sp. nov. de Portugal y España. Son nuevas sinonimias: Compsapoderus (Compsapoderus) erythropterus (Gmelin, 1790) = Attelabus intermedius Hellwig, 1795, syn. nov.; Paroplapoderus (Erycapoderus) angulipennis (Kolbe, 1886) = Paroplapoderus (Erycapoderus) angulipennis shaanxinsis Legalov, 2004, syn. nov. (Attelabidae); Aspidapion (Koestlinia) aeneum (Fabricius, 1775) = Aspidapion (Koestlinia) motschulskyi (Hochhuth, 1847), syn. nov., Taeniapion rufescens (Gyllenhal, 1833) = Taeniapion notatum (Wagner, 1912), syn. nov. (Apionidae); Larinus (Larinomesius) scolymi (Olivier, 1807) = Curculio teres Hellwig, 1795, syn. nov. (Curculionidae); Lixus paraplecticus (Linnaeus, 1758) = Curculio phellandrii Linnaeus, 1764, syn. nov. (Curculionidae); Curculio alternans Hellwig, 1795= Curculio alternans Herbst, 1795, syn. nov. (Curculionidae); Sibinia lyrata Faust, 1889= Sibinia attalica var. judea Pic, 1901, syn. nov. (Curculionidae); Phyllobius (Metaphyllobius) pomaceus Gyllenhal, 1834= Curculio prasinus Olivier, 1791, syn. nov. (Curculionidae). Son nuevas homonimias: Attelabus intermedius Hellwig, 1795 (non Attelabus intermedius Illiger, 1794); Baris marshalli Ramesha \& Ramamurthy, 2011 (non Baris marshalli Hustache, 1938). Son nuevos nombres de reemplazo: Baris ramamurthyi Alonso-Zarazaga nom. nov. para Baris bimaculata Pajni \& Kohli, 1990 (non Hustache, 1932); Archarius (Archarius) kwonleeanus Alonso-Zarazaga nom. nov. para Archarius (Archarius) parvus (Kwon \& Lee, 1990) (non Archarius (Archarius) parvus (Hong \& Wang, 1987), a fossil species); Curculio (Curculio) zhangianus Alonso-Zarazaga nom. nov. para Curculio (Curculio) helleri Pelsue \& Zhang, 2002 (non Curculio (Curculio) helleri (Voss, 1932)); Lixus trichromus Alonso-Zarazaga nom. nov. para Lixus tricolor Capiomont, 1876 (non L. tricolor (Scopoli, 1771)). Son nuevas combinaciones: Cionus affinis (Brahm, 1790), comb. nov. desde Curculio; Curculio helleri (Voss, 1932), comb. nov. desde Balaninus; Donus diversisquamosus (Legalov, 2012), comb. nov. desde Asiodonus; Donus knutelskyi (Legalov, 2012), comb. nov. desde Asiodonus; Donus potanini (Legalov, 2012), comb. nov. desde Asiodonus; Donus shokhrini (Legalov, 2012), comb. nov. desde Asiodonus; Donus streltzovi (Legalov, 2012), comb. nov. desde Asiodonus; Donus tshernyshevi (Legalov, 2012), comb. nov. desde Asiodonus; Involvulus (Teretriorhynchites) icosandriae (Scopoli, 1763), comb. nov. desde Curculio; Mecaspis alternans (Hellwig, 1795), comb. nov. desde Curculio; Otiorhynchus mucronatus (Paykull, 1792), comb. nov. desde Curculio; Pseudopoophagus constricticollis (Kojima \& Morimoto, 1993), comb. nov. desde Apionodes. Se reconsidera a Protapion interjectum boreum (Gønget, 1997) como una subespecie válida basándose en sus caracteres genitales, stat. res. Se declaran nomina protecta conforme al Art. 23.9.2. del Código los siguientes nombres: Apion apricans Herbst, 1797 (ahora en Protapion) sobre Rhinomacer flavipes O.F. Müller, 1776 (nomen oblitum), Apion genistae Kirby, 1811 (ahora en Exapion) sobre Curculio astralagi Herbst, 1795 (nomen oblitum), Curculio piceus Pallas, 1771 (ahora en Sphenophorus) sobre Curculio piceus Wulfen in Scopoli, 1763 (nomen oblitum), Curculio phyllocola Herbst, 1795 (ahora en Anthonomus) sobre Curculio resinae Fabricius, 1792 (nomen oblitum), and Rhynchaenus posticus Gyllenhal, 1813 (ahora en Hypera) sobre Curculio denigratus Panzer, 1790 (nomen oblitum). Se confirma Rhynchites laevior Faust, 1882 como especie tipo de Aphlorhynchites Sawada, 1993 mediante una acción de Primer Revisor. Se ofrecen dataciones pertinentes para algunas obras. Las referencias han sido completadas y actualizadas. Se han corregido algunas grafías erróneas en uso, entre ellas, Hylesinus taranio Danthoine (no toranio).

Palabras clave: Insectos; Coleópteros; Curculionoidea; Catálogo Paleártico; adiciones; correcciones; comentarios; dataciones; nuevos sinónimos; nuevos homónimos; nuevos nombres de reemplazo; nuevas combinaciones; confirmación de especie tipo.

Recibido/Received: 30/11/2015; Aceptado/Accepted: 4/04/2016; Publicado en línea/Published online: 25/05/2016

Cómo citar este artículo/Citation: Alonso-Zarazaga, M. A., Caldara, R., Machado, A., Maughan, N., Pelletier, J., Pierotti, H., Ren, L., Sforzi, A., Silfverberg, H. \& Skuhrovec, J. 2016. Addenda and Corrigenda to the Catalogue of Palaearctic Coleoptera, volumes 7 and 8 (Curculionoidea). Grael/sia, 72(1): e043. http://dx.doi.org/10.3989/graellsia.2016.v72.155

Copyright: (C) 2016 SAM y CSIC. Salvo indicación contraria, todos los contenidos de la edición electrónica de Graellsia se distribuyen bajo licencia de uso y distribución Creative Commons Reconocimiento no Comercial 3.0. España (cc-by-nc). 


\section{Introduction}

The Catalogue of Palaearctic Coleoptera (thereafter, the Catalogue) is a multi-authored, eight volume work which tried to convey the knowledge gathered at that time on the systematics and nomenclature of the Palaearctic beetles. The last two volumes, coordinated by one of us (MAA-Z), dealt with the hyperdiverse superfamily Curculionoidea.

The editors did not give the coordinator the opportunity to check a final draft of the references. They modified these, introducing errors not present in the originals. Neither was the coordinator able to carry out the same final check for the "New nomenclatural and taxonomic acts and comments" section. During the editing, many mistypings were introduced, and the section "subfamily Entiminae, taxa incertae sedis" was misplaced. The placement of more exact datings after each reference was not allowed, a fact that has impeded the correct application of the Principle of Priority in several cases, even if the coordinator has done his best to alleviate the problems derived from this inamovible rule, so easy to implement as an addition to every reference record [cf. e.g. Alonso-Zarazaga \& Lyal (1999), Bouchard et al. (2011)], by informing the different authors of the problems found. In several important works published the same year and describing many taxa which are homonyms or synonyms, priority depends on these datings whose implementation was not allowed by the editors. Some examples are given here in the corrections to the references.

Since volume $8^{\text {th }}$ is the final one of the series, there was no possibility of corrections of the errata in the same series, as it was offered to authors of the 7 previous volumes. A $9^{\text {th }}$ volume for Errata from volumes 1-8, should have been foreseen, but was not, to the detriment of this particular taxonomic group (Curculionoidea) and, what is worse, of the authors' rights. In the absence of such a fair offer, we provide here the corrections we have found, and update the content to $31^{\text {st }}$ December 2013.

\section{Material and methods}

The system for giving the additions, corrections and comments is similar to that implemented for the Errata section of the volumes of the Catalogue. The authorship of every comment, addition or correction is given between square brackets, except for new sections, where the author's name is centered as in the original work. The new taxa and country records have been published elsewhere, except for one species that is made available here. However, the new, original comments and corrections, except for minor ones, are treated as an inclusion to the corresponding pages and sections of the "New nomenclatural and taxonomic acts, and comments" in the Catalogue, and then mirrored in the text. References to be added to the two volumes of the Catalogue are formatted as they were in that work, but references used exclusively for this article follow the editorial rules of the journal and are placed at the end as usual.

The first author acted again as coordinator of this article. Any modification not having the name of its author between square brackets is to be credited to Alonso-Zarazaga.

\section{Taxonomy}

Volume 7

p. 21. Although the Editors correctly gave the year 1792 for the effective publication of Fabricius's Entomologia systematica..., they did not give even an approximate date for it, which is important because of the relative precedence with other publications appearing the same year (e.g. by Paykull and Rossi). My own research on this subject can be summarized as follows. According to Evenhuis (1997: 248), vol. 1, part 1 ([XX] +330 pp.) appeared on $22^{\text {nd }}$ December 1792 and part 2 on $4^{\text {th }}$ May 1793 Given the date late in 1792 identified for the first part, one might suspect both parts to have appeared together. However, both parts were recorded as being for sale at St. Michael's Book Fair in the Allgemeines Verzeichniss der Bücher, welche in der Frankfurter und Leipziger Michaelismesse des 1792 Jahres entweder ganz neu gedruckt, oder sonst verbessert, wieder aufgeleget worden sind, auch insküftige noch herauskommen sollen, p. 217. This is more in agreement with the fact that species in these books were mentioned with correct pages by Panzer in his Faunae Insectorum Germanicae initia, Hefts 2 and 3, dated respectively October and November 1792. Consequently, Fabricius's books are here dated as of $30^{\text {th }}$ September 1792 (cf. Evenhuis, 2014).

p. 66, delete the list of Nomina dubia of species of Anthribus; it is already in its right place on p. 109

p. 71 , add to New synonyms:

Attelabus intermedius Hellwig, 1795, syn. nov. of Compsapoderus (Compsapoderus) erythropterus (Gmelin, 1790), and at the same time a junior homonym (hom. nov.) of Attelabus intermedius Illiger, 1794. Illiger gave as type locality Braunschweig, where Hellwig was living, so it is very probable that he received his specimens from Hellwig or he only saw those in Hellwig's collection.

p. 72, add to Priority:

Curculio icosandriae Scopoli, 1763 was placed in the Catalogue on p. 129 among the species in "family Rhynchitidae, nomina dubia". Unknown to the author at that time, this species had been placed in synonymy of Rhynchites conicus (Illiger, 1807) by Schoenherr (1833: 231). This synonymy was correctly reversed (because of priority) by Kittel 
(1883: 38), who used Rhynchites icosandriae (Scopoli) as the valid name of the species. This synonymy has been overlooked by most authors in the systematic field, with some exceptions (e.g. Boselli, 1928: 198; Antonie, 2007: 67). Voss (1969: 133) rejected the synonymy without any explanation and used instead as valid Involvulus coeruleus [sic!] (DeGeer, 1775) (correctly caeruleus). However, a nomen protectum declaration of the latter name cannot be done, since the combination Rhynchites icosandriae (Scopoli) has been used as valid during the $20^{\text {th }}$ century by several authors for the same species concept (i.e. Rhynchites conicus or R. caeruleus or any of their combinations), mostly in the Forestry field, e.g. by Wellhouse (1922: 1104), Craveri (1926: 122) or Ximénez de Embún y González-Arnao (1962: 322) and the requirements of Art. 23.9.1.1 are not met. On the other hand, in the last 50 years the same species has been named either Rhynchites conicus or $R$. caeruleus (or any other combination of these, mostly with Involvulus) by different authors. I consider that stability is better served in this case by using the oldest available name, following the Principle of Priority, and consequently, the name Involvulus (Teretriorhynchites) icosandriae (Scopoli, 1763), comb. nov. is used as valid for this species. Since the species is well known and easy to identify, there is no need of a neotype designation.

p. 77 , add to New synonymies:

Paroplapoderus (Erycapoderus) angulipennis shaanxinsis Legalov, 2004, syn. nov. of Paroplapoderus (Erycapoderus) angulipennis (Kolbe, 1886). Based on the study of topotypical materials (Institute of Zoology, Chinese Academy of Sciences, Beijing), showing intergradation in all the supposedly diagnostic characters.

p. 77, add a section Type species designation:

Aphlorhynchites Sawada, 1993 is usually considered to have as type species Rhynchites laevior Faust, 1882, a junior synonym of Rhynchites amabilis Roelofs, 1874. This original type species designation is found in Sawada (1993: 50). However, overlooked by Alonso-Zarazaga \& Lyal (1999: 42) and by Alonso-Zarazaga (2011a: 122), Sawada (1993: 12) mentioned as type species Curculio pubescens Fabricius, 1775. To avoid any further change and acting as the First Reviser (Art. 24.2.3), I select as valid the designation made by Sawada on p. 50 (Rhynchites laevior) and reject as invalid his designation on p. 12.

p. 78, lines 1,12 and 19 , correct 1858 to 1859

p. 79, line 30, delete (Apion) after 183

p. 81, add to New synonymies:

Aspidapion (Koestlinia) motschulskyi (Hochhuth, 1847), syn. nov. of Aspidapion (Koestlinia) aeneum (Fabricius, 1775). Giusto (2011) considered this to be an eastern vicariant of $A$. aeneum, but the characters on which the distinction is based are too weak and fit into the current known variability of $A$. aeneum, and these faint differences are probably related to the more steppic condition of the Eastern part of the species area.

p. 81, after Apion parvulum and Apion serpyllicola, correct 1858 to 1859

p. 82, delete the paragraph on priority of Catapion semicyaneum over Catapion burdigalense; the reverse is true, as explained below in a comment on p. 164

p. 82, the reversal of precedence of Exapion genistae (Kirby, 1811) (nomen protectum) over Curculio astralagi Herbst, 1795 (nomen oblitum) is done below

p. 82, the reversal of precedence of Perapion marchicum (Herbst, 1797) over Curculio aterrimus Linnaeus, 1758 cannot be done under Art. 23.9.2 of the Code; an application will be submitted to the International Commission on Zoological Nomenclature

p. 83, add at the end of the Apionidae, a new section:

\section{Reversal of precedence:}

Rhinomacer flavipes O.F. Müller, 1776 was absent from the list of synonyms of Protapion apricans (Herbst, 1797). This synonymy dates back to Schoenherr (1833, p. 280) and had been overlooked. For the sake of stability, it is convenient to declare Apion apricans Herbst, 1797 a nomen protectum. Rhinomacer flavipes O.F. Müller, 1776 meets the requirements of Art. 23.9.1.1 (and is here declared a nomen oblitum) and Apion apricans Herbst, 1797 (now Protapion apricans) meets those of Art. 23.9.1.2 (and is here declared a nomen protectum). In accordance with Art. 23.9.2, I hereby consider that the younger name is valid for this species and give evidence that the conditions of Art. 23.9.1.2 are met by quoting the following references: Abbazzi \& Maggini (2009), Abbazzi \& Osella (1992), AlonsoZarazaga (1990), Alonso-Zarazaga (2011b), AlonsoZarazaga \& Lyal (1999), Avgin \& Colonnelli (2011), Benedikt et al. (2010), Bertram \& Jourdheuil (1968), Braunert (2009), Colonnelli (2003), Dedûhin (2012), Germann (2010), Gønget (1997), Knutelski (2005), Knutelski \& Knutelska (2014), Kolařík \& Rotrekl (2013), Lohse (1981), Mazur (2003), Pelletier (2005), Podlussány (2001), Poiras (1998), Pywell et al. (2005), Telnov (2004), Wanat \& Mokrzycki (2005), Wiech \& Wnuk (1990).

Curculio astralagi Herbst, 1795 has been in synonymy of Apion genistae Kirby, 1811 (now in Exapion) since Schoenherr (1833, p. 271). Not being a homonym of Attelabus astragali Paykull, 1800, it has priority over Kirby's species. However, it has not been used as a valid name for a species since Gozis's (1881) intent to reinstate it under the emendation Apion astragali. Some more information can be found in Alonso-Zarazaga (2011b: 82). For the sake of stability, it is convenient to declare Apion genistae 
Kirby, 1811 a nomen protectum. Curculio astralagi Herbst, 1795 meets the requirements of Art. 23.9.1.1 (and is here declared a nomen oblitum) and Apion genistae Kirby, 1811 (now Exapion genistae) meets those of Art. 23.9.1.2 (and is here declared a nomen protectum). In accordance with Art. 23.9.2, I hereby consider that the younger name is valid for this species and give evidence that the conditions of Art. 23.9.1.2 are met by quoting the following references: AlonsoZarazaga (1990, 2002, 2011), Alziar (2015), Benedikt et al. (2010), Cholewicka (1981), Deakin (2009), Ehret (1986, 1989, 1991, 1994), Heijerman (1993), Kloet \& Hincks (1977), Lohse (1981), Morris (2003), Moulin \& Viallier (1989), Offer et al. (2003), Papp (2000, 2012), Pelletier (2005, 2014), Simpson (2001), Syrett et al. (1999), Tempère \& Péricart (1989), Webb et al. (2010).

p. 85 , add:

\section{Dryophthoridae \\ M. A. Alonso-Zarazaga}

Homonymy and reversal of precedence

Curculio piceus Pallas, 1771, hom. nov. of Curculio piceus Wulfen in Scopoli, 1763. The latter species identity is unknown, not having been mentioned since the $18^{\text {th }}$ century, while the former is in current usage as Sphenophorus piceus. For the sake of stability, it is convenient to declare Pallas's species a nomen protectum. Curculio piceus Wulfen in Scopoli, 1763 meets the requirements of Art. 23.9.1.1 (and is here declared a nomen oblitum) and Curculio piceus Pallas, 1771 (now Sphenophorus piceus) meets those of Art. 23.9.1.2 (and is here declared a nomen protectum). In accordance with Art. 23.9.2, I hereby consider that the younger name is valid for this species and give evidence that the conditions of Art. 23.9.1.2 are met by quoting the following references: AlonsoZarazaga et al., 2006; Avgin \& Colonnelli, 2011; Benedikt et al., 2010; Boukli Hacene et al., 2011; Caldara et al., 2010; Carpaneto et al., 2006; Cunev, 2013; Cunev \& Majzlan, 1998; El-Mergawy et al., 2011; El-Retail et al., 1973; Ghahari \& Colonnelli, 2012; Gültekin, 2013; Legakis, 1990; Lyal, 2011; Majzlan, 2014; Majzlan \& Majzlan, 2011; Mifsud \& Colonnelli, 2010; Modarres Awal \& Hossein Pour, 2010; Mukhtarova \& Abdurakhmanov, 2015; Podlussány, 2001; Podlussány \& György, 2008; Schmidt et al., 2005; Tracy \& DeLoach, 1998; Ugarte \& Alonso-Zarazaga, 2002; Wanat, 2004.

p. 88 , add at the end of Curculionidae: Scolytinae the following Comment:

The type species of Hylastes Erichson, 1836 is Bostrichus ater Paykull, 1800 by subsequent designation by Westwood (1838: 39), as recognized, e.g., by Alonso-Zarazaga \& Lyal (2009: 62). However, unknown to these authors, since the renowned catalogue of World Scolytidae and Platypodidae
(Wood \& Bright, 1992: 45) gives this name as available, Bostrichus ater Paykull is a misidentification (misapplication) of the nominal species Bostrichus ater Fabricius, 1792 (now in synonymy of Pityogenes bidentatus (Herbst, 1783), and, consequently, it is not available. No author seems to have called the attention upon this anomalous situation, which is being uncritically copied from catalogue to catalogue. Paykull (1800) mentions that he has kept the Fabrician name even if his specimens and those received from Fabricius himself do not match the Fabrician description. This name is also a homonym of Bostrichus ater Rossi, 1792 and of the Fabrician species, if someone would not consider it a misapplication. This problem should be considered for an application to the International Commission on Zoological Nomenclature by the interested authors. Otherwise, the correct name for the species would be Hylastes pinicola Bedel, 1888, since Hylesinus chloropus sensu Duftschmid, 1825 is another misidentification (see below).

p. 89 , add:

\section{Curculionidae: Baridinae \\ M. A. Alonso-Zarazaga}

New homonyms and replacement name

Baris bimaculata Pajni \& Kohli, 1990 [as bimaculatus, incorrect original spelling], hom. nov. of Baris bimaculata Hustache, 1932. It is here replaced with Baris ramamurthyi Alonso-Zarazaga, nom. nov. Named after my good colleague and friend, and outstanding Indian specialist in Curculionoidea, Dr. V.V. Ramamurthy.

Baris marshalli Ramesha \& Ramamurthy, 2011, hom. nov. of Baris marshalli Hustache, 1938. Dr. Ramamurthy has been informed of the need for a replacement name.

p. 90 , transfer the four species under "family Nemonychidae, nomina dubia" to volume 8 , p. 501, under "superfamily Curculionoidea, nomina dubia"

p. 91, correct the spelling küsteri to kuesteri in synonymy of Anthribus nebulosus Forster, 1770

p. 92, add under Basitropis: werneri Frieser, 1995a: 41 A: UP

p. 93, add FR(Corse) to distribution of Pseudeuparius centromaculatus (Gyllenhal, 1833):

p. 93, add in synonymy of Pseudeuparius centromaculatus (Gyllenhal, 1833):

pictus Betta, 1857: 20 (Tropideres)

p. 97, add under Phloeobius: crassicollis Jordan, 1933a: 6 A: UP ORR gigas longicornis Fabricius, 1798: 160 (Anthribus) A: GUI GUX HKG TAI YUN ORR nigroungulatus Gyllenhal, 1833: 133 (Anthribus)

p. 97, add IR to distribution of Platystomos albinus (Linnaeus, 1758)

p. 99, add FR to distribution of Gonotropis gibbosa LeConte, 1876 
p. 102, add in synonymy of Dissoleucas niveirostris (Fabricius, 1798):

brevirostris Panzer, 1798b: 9 (Anthribus)

p. 102, add E: CT ST UK to distribution of Exechesops foliatus Frieser, 1995

p. 103, add MA to distribution of Noxius curtirostris (Mulsant \& Rey, 1861)

p. 103, correct year for maculosa Mulsant to 1859 [in synonymy of Rhaphitropis marchica (Herbst, 1797)]

p. 104, add MA A: IN to distribution of Araecerus fasciculatus (DeGeer, 1775)

p. 109, add under "family Anthribidae, nomina dubia" Anthribus glaber O.F. Müller, 1776: 57 E: DE

p. 109, delete Anthribus lividus Olivier, 1789 (a synonym of Rhyzobius litura (Fabricius, 1787) in Coccinellidae)

p. 109, delete Anthribus unicolor Olivier, 1789 (a synonym of Cychramus luteus (Fabricius, 1787) in Nitidulidae)

p. 109, add under Aglycyderes: ornatus Knížek, 2012a: 504 A: PAQA YE(Suqutra)

p. 109, transfer Auletobius (Auletobius) fukienensis Voss, 1941 to synonymy of Auletobius (Auletobius) fumigatus (Roelofs, 1874)

p. 110, add NP to distribution of Auletobius (Auletobius) ghumensis Legalov, 2007

p. 110, add under Auletobius subgenus Auletobius: jizushannsis Legalov, 2010: 168 A: YUN qinlingensis Legalov, 2010: 166 A: SHA

p. 113, add in synonymy of Byctiscus betulae (Linnaeus, 1758):

alni Schrank, 1798: 474 (Involvulus) [RN]

p. 113, delete one SC from distribution of Byctiscus fausti [Ren]

p. 116, correct year and page for Capylarodepus (Capylarodepopsis) medvedevi Legalov to 2003b: 179 [Ren]

p. 117, add under Deporaus subgenus Deporaus: hengjanensis Legalov, 2011: 295 A: SHX

p. 117, indent and reduce size font for illibatus Voss, as a synonym to Eusproda proxima (Faust, 1882)

p. 119, transfer lacunosus Voss, 1949 to genus Eugnamptus, and place rusticus Legalov, 2003 as its synonym

p. 119, add AP to distribution of "Caenorhinus" marginatus (Pascoe, 1883)

p. 120, add under Auletomorphus subgenus Auletomorphus:

habashanensis Legalov, 2011: 298 A: YUN

p. 121, add under Cyllorhynchites subgenus Cyllorhynchites:

sarahae Biondi, Colonnelli \& Ringenbach, 2013: $2 \mathrm{~N}$ : LB

p. 122, add under Involvulus subgenus Involvulus: hartmanni Legalov, 2011: 296 A: NP

p. 122, replace Involvulus (Teretriorhynchites) caeruleus caeruleus (DeGeer, 1775) with Involvulus (Teretriorhynchites) icosandriae icosandriae
(Scopoli, 1763) and place caeruleus (DeGeer, 1775 ) as its synonym

p. 122, replace caeruleus iranensis Legalov with icosandriae iranensis Legalov

p. 122, replace caeruleus ussuriensis Voss with icosandriae ussuriensis Voss

p. 123, delete indentation for Lasiorhynchites (Nelasiorhynchites) brevirostris Roelofs, 1874

p. 123, replace Lasiorhynchites (Nelasiorhynchites) olivaceus Gyllenhal, 1833 with L. (N.) comatus Gyllenhal, 1833 as the valid name, and place olivaceus as a synonym; the synonymy was established by Desbrochers des Loges (1869c, p. 383), who selected Rhynchites comatus as the valid name; a reversal of precedence cannot be made, since Bedel (1913, p. 190) also used the name Rhynchites comatus as valid

p. 123, add LT to distribution of Involvulus (Teretriorhynchites) pubescens (Fabricius, 1775)

p. 124, add [NO] to crassicornis Gmelin in synonymy of Mecorhis (Pseudomechoris) aethiops (Bach, 1854); three synonyms have priority over $M$. aethiops and this problem should be addressed, since it does not seem possible to formally declare this species a nomen protectum

p. 124, add in synonymy of Mecorhis (Pseudomechoris) aethiops (Bach, 1854):

crassirostris Gmelin, 1790: 1806 (Curculio) [DA, NO]

p. 129, delete Curculio icosandriae Scopoli, 1763 and Curculio violascens Schrank, 1781

p. 130, add in synonymy of Compsapoderus (Compsapoderus) erythropterus (Gmelin, 1790): intermedius Hellwig, 1795: 146 (Attelabus) [HN]

p. 131, delete FUJ from distribution of Heterapoderus (Heterapoderus) ageniculatus Legalov, 2007 (no locality in the original description corresponds to this province)

p. 140, place angulipennis shaanxinsis Legalov, 2004 in synonymy with Paroplapoderus (Erycapoderus) angulipennis (Kolbe, 1886)

p. 141, add SHA to distribution of Phymatapoderus euflavimanus Legalov, 2003

p. 143, add LE to distribution of Amorphocephala coronata [Sforzi]

p. 143, add to synonymy of Amorphocephala coronata (Germar, 1817):

italicus Guérin-Méneville, 1833: pl. 36 (Brentus)

p. 144, add under Amorphocephala the species piochardi Bedel, 1878: clxxxiv (Amorphocephalus) and its synonyms, from Symmorphocerus

p. 144, add CY IS to distribution of Amorphocephala piochardi (Bedel, 1878)

p. 144, add under Eremoxenus: maroccanus Mantilleri, 2012: 407 N: MO

p. 144, transfer Symmorphocerus piochardi (Bedel, 1878 ) and its synonyms to Amorphocephala

p. 145, transfer Calodromus horishanus Kôno under synonymy of Calodromus ito Heller, 1910 below 
p. 145, add SC to distribution of Cyphagogus iwatensis Morimoto, 1976

p. 146, transfer genus Carcinopisthius Kolbe as a subgenus of genus Hoplopisthius Senna, 1892, and also its single species and synonyms

p. 146, add under genus Hoplopisthius the subgenus Carcinopisthius Kolbe

p. 146, delete Pseudotaphroderes Bolkay and Stratopisthius Senna \& Calabresi from synonymy under Hoplopisthius subgenus Carcinopisthius

p. 146, correct year for Hoplopisthius (Carcinopisthius) oberthueri Senna to $1892 \mathrm{c}$

p. 146, add under genus Hoplopisthius: subgenus Hoplopisthius Senna, 1892b: 451 type species Hoplopisthius trichemerus Senna, 1892

p. 146, add under synonymy of Hoplopisthius (Hoplopisthius) trichemerus Senna, 1892: celebensis Kolbe, 1892: 174

p. 147, delete the tribe Microtrachelizini Zimmerman and transfer all its contents to the tribe Hoplopisthiini Senna \& Calabresi on p. 146

p. 147, delete the genus Aneorhachis and its species, the supposed Bhutanese locality "Maria Basti" is in the Indian district of Jalpaiguri, out of the geographical limits of the Catalogue

p. 147, add under tribe Microtrachelizini:

genus Entomopisthius Muizon, 1959: 77 type species Entomopisthius leleupi Muizon, 1959 laevigatus Mantilleri, 2011: 22 A: NP

p. 147, delete BT from distribution of Higonius (Higonius) cilo Lewis, 1883, the supposed Bhutanese locality "Maria Basti" is in the Indian district of Jalpaiguri, out of the geographical limits of the Catalogue

p. 147, transfer Microtrachelizus apertus Kleine under syonymy of M. bhamoensis (Senna, 1892)

p. 147, add under Microtrachelizus:

bhamoensis Senna, 1892b: 456 (Trachelizus) A: NP SD YUN ORR coomani Damoiseau, 1987: 56 A: NP ORR

p. 147, add as synonyms of Microtrachelizus contiguus (Senna, 1893):

sternopilosus Damoiseau, 1987: 590

temporalis Damoiseau, 1987: 590

p. 149, add AL to distribution of Apion haematodes haematodes Kirby, 1808

p. 150, add CY to distribution of Hoplopodapion poupillieri (Wencker, 1864)

p. 151, add AL to distribution of Perapion (Perapion) affine (Kirby, 1808)

p. 151, add HU PL SK KI to distribution of Perapion (Perapion) connexum (Schilsky, 1902)

p. 151, add MA to distribution of Perapion (Perapion) hydrolapathi (Marsham, 1802)

p. 151, add [NP] to Perapion (Perapion) marchicum (Herbst, 1797) and as a synonym: aterrimum Linnaeus, 1758: 378 (Curculio) [NO]

p. 151, add AL to distribution of Perapion (Perapion) oblongum (Gyllenhal, 1839) p. 151, add AL MA to distribution of Perapion (Perapion) violaceum violaceum (Kirby, 1808)

p. 152, add AL to distribution of Phrissotrichum (Phrissotrichum) tubiferum (Gyllenhal, 1839)

p. 152, add GB to distribution of Pseudoperapion brevirostre (Herbst, 1797)

p. 153, add AL MA to distribution of Aspidapion (Aspidapion) radiolus radiolus (Marsham, 1802)

p. 153, add LU XIN to distribution of Aspidapion (Aspidapion) validum (Germar, 1817)

p. 153, add AL MA to distribution of Aspidapion (Koestlinia) aeneum (Fabricius, 1775) and add to synonymy: cupricollis Panzer, 1798: 64 (Attelabus) violascens Schrank, 1781: 105 (Curculio)

p. 154, add to Harpapion: borisi Wang \& Alonso-Zarazaga, 2013: 37 A: YUN coelebs Korotyaev, 1987b: 100 (Aspidapion) A: YUN

safranum Wang \& Alonso-Zarazaga, 2013: 33 A: GUA vietnamense Korotyaev, 1985: 139 (Aspidapion) A: YUN ORR

p. 154, add under Pseudaspidapion: botanicum Alonso-Zarazaga \& Wang, 2011: 43 A: BEI SHA

p. 154, delete coelebs Korotyaev under Pseudaspidapion (transferred to Harpapion)

p. 154, add CY to distribution of Acentrotypus brunnipes (Boheman, 1839)

p. 154, add MA to distribution of Ceratapion (Acanephodus) onopordi onopordi (Kirby, 1808)

p. 154, add LT to distribution of Ceratapion (Angustapion) austriacum (Wagner, 1904)

p. 155, add CY MA to distribution of Ceratapion (Ceratapion) damryi (Desbrochers des Loges, 1894)

p. 156, correct year for Ceratapion (Echinostroma) scalptum scalptum (Mulsant \& Rey) to 1859

p. 156, add AL to distribution of Diplapion detritum (Mulsant \& Rey) and correct year to 1859

p. 157, add CY to distribution of Omphalapion concinnum (Schilsky, 1906)

p. 157, add CY to distribution of Omphalapion dispar (Germar, 1817)

p. 157, add IR and NARi to distribution of Omphalapion hookerorum (Kirby, 1808)

p. 157, add [unnecessary RN] to sorbi Fabricius in synonymy of Omphalapion laevigatum (Paykull, 1792)

p. 157, transfer Omphalapion fossicolle Desbrochers des Loges, 1889 between $O$. dispar Germar and O. hookerorum Kirby

p. 158, add CT to distribution of Exapion fuscirostre fuscirostre (Fabricius, 1775) and add in synonymy: teretirostre Herbst, 1795: 106 (Curculio) [RN] [DA]

p. 158 , add $[\mathrm{HN}]$ to curvirostre Herbst in synonymy of Exapion fuscirostre fuscirostre (Fabricius, 1775) 
p. 158, delete venustum Herbst in synonymy of Exapion fuscirostre fuscirostre (Fabricius, 1775); a misidentification of Curculio venustus Fabricius, 1781

p. 158, correct year for funiculare Mulsant \& Rey to 1859 [in synonymy of Exapion genistae (Kirby, 1811)]

p. 159, correct year, page and original genus of nigrirostris Fabricius to 1798: 163 (Attelabus) in synonymy of Exapion ulicis (Forster, 1771)

p. 159, delete Lepidapion (Hidryocneme) canariense (Wagner, 1914)

p. 159, add in synonymy of Lepidapion (Hidryocneme) senex (Wollaston, 1864): canariense Wagner, 1914a: 23 (Apion)

p. 160, add BEI to distribution of Melanapion mandli (Schubert, 1959)

p. 160, add BEI to distribution of Melanapion naga (Nakane, 1963)

p. 161, add AL LT to distribution of Squamapion atomarium (Kirby, 1808)

p. 161, add AL to distribution of Squamapion oblivium (Schilsky, 1902)

p. 162, correct year for parvulum Mulsant \& Rey to 1859 [in synonymy of Squamapion serpyllicola Wencker, 1864)]

p. 162, add AL to distribution of Squamapion vicinum (Kirby, 1808)

p. 162, add MA to distribution of Taeniapion rufescens (Gyllenhal, 1833); recently Giusto (2012) resurrected Taeniapion notatum (Wagner, 1912) from synonymy under T. rufescens (Gyllenhal, 1833), based mostly on details of the scale coloration and female rostrum measurements; in my opinion, these features do not allow this to be maintained as a valid species, when the male genitalia are identical and some females outside the range of the supposed species show the same characters. Moreover, the specimens supporting Giusto's statement were collected on two different plants, which raises the possibility of a mixture of species, given the fact that Taeniapion species are generally monophagous; thus, the synonymy is here maintained until more research on the subject is done (syn. nov.)

p. 162, add MA to distribution of Taeniapion rufulum (Wencker, 1864)

p. 162, add AL to distribution of Taeniapion urticarium urticarium (Herbst, 1784)

p. 163, add AL MA to distribution of Malvapion malvae (Fabricius, 1775) and Pseudapion rufirostre (Fabricius, 1775)

p. 164, delete the round brackets and their content after the type species of Pseudocatapion Wagner

p. 164, add CY to distribution of Catapion curtisii (Stephens, 1831)

p. 164, add CY to distribution of Catapion jaffense (Desbrochers des Loges, 1896)

p. 164, add CY to distribution of Catapion meieri (Desbrochers des Loges, 1901) p. 164, add AL MA to distribution of Catapion pubescens (Kirby, 1811)

p. 164, correct the year for Catapion semicyaneum (Mulsant \& Rey) to 1859 and use as valid name Catapion burdigalense (Wencker, 1859), which has priority: the latter appeared on 23-III-1959 while the former can be recorded only on 10-V-1859

p. 164, add CY to distribution of Catapion seniculus (Kirby, 1808)

p. 165, add AL to distribution of Cyanapion (Bothryorrhynchapion) gyllenhalii (Kirby, 1808)

p. 165, add AL to distribution of Cyanapion (Bothryorrhynchapion) platalea (Germar, 1817)

p. 165, add AL to distribution of Cyanapion (Cyanapion) columbinum (Germar, 1817)

p. 165, add MA to distribution of Eutrichapion (Cnemapion) vorax (Herbst, 1797)

p. 166, add AL to distribution of Eutrichapion (Eutrichapion) viciae (Paykull, 1800)

p. 166, add AL RO to distribution of Eutrichapion (Psilocalymma) facetum (Gyllenhal, 1839)

p. 166, add CY to distribution of Eutrichapion (Psilocalymma) punctiger (Paykull, 1792)

p. 167, add CY to distribution of Hemitrichapion (Tinocyba) filicorne (Wencker, 1864)

p. 167, add CY to distribution of Hemitrichapion (Tinocyba) juniperi (Boheman, 1839)

p. 168, add MA to distribution of Holotrichapion (Apiops) pisi (Fabricius, 1801)

p. 168, add AL to distribution of Holotrichapion (Holotrichapion) ononis (Kirby, 1808)

p. 169, add AL to distribution of Oxystoma cerdo (Gerstaecker, 1854)

p. 169, add to synonymy of Oxystoma craccae (Linnaeus, 1767): craccae Thunberg, 1813: 382 (Apion) [HN]

p. 170, add CY to distribution of Ischnopterapion (Chlorapion) cognatum (Hochhuth, 1851)

p. 170, add AL to distribution of Ischnopterapion (Chlorapion) virens (Herbst, 1797) and I. (I.) aeneomicans aeneomicans (Wencker, 1864)

p. 170, add AL NARi to distribution of Ischnopterapion (Ischnopterapion) loti (Kirby, 1808)

p. 170, add to synonymy of Ischnopterapion (Ischnopterapion) loti (Kirby, 1808): punctigerum Thunberg, 1815: 118 (Apion)

p. 171, add CY to distribution of Stenopterapion (Stenopterapion) argamani Friedman \& Freidberg, 2007

p. 171, add NARi to distribution of Stenopterapion (Stenopterapion) meliloti (Kirby, 1808)

p. 173, add AL to distribution of Protapion angusticolle (Gyllenhal, 1833)

p. 173, correct year for longimanum Mulsant \& Rey to 1859 [in synonymy of Protapion angusticolle (Gyllenhal, 1833)]

p. 173, add MA to distribution of Protapion apricans (Herbst, 1797) and [NP] [see New Acts] and add to synonymy: 
flavipes O.F. Müller, 1776: 90 (Rhinomacer) [NO]

p. 173, add AL to distribution of Protapion assimile assimile (Kirby, 1808)

p. 173, delete $[\mathrm{HN}]$ from meridionale Wencker in synonymy of Protapion assimile assimile (Kirby, 1808)

p. 174, add MA to distribution of Protapion dentipes (Gerstaecker, 1854)

p. 174, add AL to distribution of Protapion difforme (Germar, 1818)

p. 174, add AL to distribution of Protapion fulvipes fulvipes (Geoffroy, 1785)

p. 174, add AL MA to distribution of Protapion interjectum interjectum (Desbrochers des Loges, 1895); Mifsud \& Colonnelli (2010) placed Protapion interjectum boreum in synonymy as a mere local colour variety, but I cannot follow their procedure given the constant differences in the male genitalia of the northern populations, as already pointed out by Nyholm (1950); its subspecies status is here maintained (stat. res.)

p. 174, add AL to distribution of Protapion laevicolle (Kirby, 1811)

p. 174, add AL to distribution of Protapion nigritarse (Kirby, 1808)

p. 174, add AL to distribution of Protapion ononidis (Gyllenhal, 1827)

p. 174, correct year for Protapion pedale (Mulsant \& Rey) to 1859

p. 174, add AL to distribution of Protapion schoenherri (Boheman, 1839)

p. 175, add AL to distribution of Protapion trifolii (Linnaeus, 1768)

p. 176, add to synonymy of Pseudoprotapion astragali astragali (Paykull, 1800): astragali Thunberg, 1815: 118 (Apion) [HN]

p. 177, add CY to distribution of Allomalia setulosa (Tournier, 1868)

p. 177, add E: SP N: CI MO and A: YE to distribution of Corimalia martini

p. 177, add MA to distribution of Corimalia pallida (Olivier, 1807)

p. 178, add MA to distribution of Corimalia tamarisci (Gyllenhal, 1838)

p. 178, add CY to distribution of Hypophyes minutissimus (Tournier, 1868)

p. 179, add PL to distribution of Dieckmanniellus chevrieri (Boheman, 1845)

p. 179, add BE CY to distribution of Dieckmanniellus nitidulus (Gyllenhal, 1838)

p. 179 , add:

genus Kantohia Alonso-Zarazaga \& Perrin, 2011: 46 type species Shiva taiwanus Kantoh \& Kojima, 2009 taiwana Kantoh \& Kojima, 2009: 165 (Shiva) A: TAI

p. 180, add WS to distribution of Nanomimus hemisphaericus (Olivier, 1807) p. 180, add AL to distribution of Nanophyes brevis brevis Boheman, 1845 and N. globiformis Kiesenwetter, 1864

p. 180, add EN LA to distribution of Nanophyes globiformis Kiesewetter, 1864

p. 181, add AL and NARi to distribution of Nanophyes marmoratus marmoratus (Goeze, 1777)

p. 182, delete the genus Shiva and transfer the species taiwanus to genus Kantohia on p. 179

p. 182, add CY to distribution of Brachycerus aegyptiacus Olivier, 1807

p. 182, add under Brachycerus: anatolicus Arzanov \& Friedman, 2012: 53 A: TR

p. 183, add under Brachycerus: groneri Friedman \& Sagiv, 2011: 50 A: IS hermoniacus Friedman \& Sagiv, 2011: 52 A: IS

p. 183, delete muricatus Fabricius from synonymy of Brachycerus foveicollis Gyllenhal, 1833. It is a misidentification of $B$. muricatus Olivier, 1790, not a homonym.

p. 183, correct page for Brachycerus muricatus Olivier to 186

p. 184, add under Brachycerus: skoupyi Arzanov, 2011: 57 A: SY wizeni Friedman \& Sagiv, 2011: 60 A: IS

p. 185, add SC to distribution of Desmidophorus hebes (Fabricius, 1781)

p. 185, add SB to distribution of Dryophthorus corticalis (Paykull, 1792)

p. 186, add LU A: TR to distribution of Sitophilus granarius (Linnaeus, 1758)

p. 186, add in synonymy of Sitophilus granarius (Linnaeus, 1758): flavipes Panzer, 1798: 55 (Curculio) [HN]

p. 187, add under Sitophilus: kakourisi Alziar \& Colonnelli, 2009: 112 A: CY IS

p. 187, add CT LU to distribution of Sitophilus oryzae (Linnaeus, 1763):

p. 187, add in synonym of Sitophilus oryzae (Linnaeus, 1763):

bituberculatus Fabricius, 1781: 171 (Curculio)

p. 187, add MA to distribution of Sitophilus zeamais Motschulsky, 1855

p. 189, add MA to distribution of Rhynchophorus ferrugineus (Olivier, 1791)

p. 189, delete vulneratus Panzer from synonymy of Rhynchophorus ferrugineus (Olivier, 1791), it is a valid species out of the geographical limits of the Catalogue

p. 191, add LU A: TR to and delete MA from distribution of Sphenophorus abbreviatus (Fabricius, 1787)

p. 191, add [HN] to Curculio porculus Fabricius in synonymy of Sphenophorus abbreviatus (Fabricius, 1787)

p. 191, add MA to distribution of Sphenophorus parumpunctatus Gyllenhal, 1838

p. 191, delete MA from distribution and add [NP] to Sphenophorus piceus (Pallas, 1771) 
p. 194, add LU to distribution of Grypus brunnirostris (Fabricius, 1792) [Caldara]

p. 194, correct year for atrirostris Fabricius to 1782 [in synonymy of Grypus equiseti (Fabricius, 1775)]

p. 194, add LU to distribution of Grypus equiseti (Fabricius, 1775) [Caldara]

p. 195, add LU to distribution of Notaris acridulus (Linnaeus, 1758) [Caldara]

p. 195, correct author, year and page for Notaris aethiops to Paykull, 1792: 49 (Fabricius's reference is just a later use mentioning Paykull)

p. 195, add LU A: TR to distribution of Notaris scirpi (Fabricius, 1792) [Alonso-Zarazaga, Caldara]

p. 197, transfer genus Siraton and its species to Vol. 8, p. 497 under a section "subfamily Molytinae, incertae sedis"

p. 197, add LU to distribution of Thryogenes atrirostris Lohse, 1992 [Caldara]

p. 197, add LU to distribution of Thryogenes festucae (Herbst, 1795) [Caldara]

p. 197, add LU to distribution of Thryogenes nereis (Paykull, 1800) [Caldara]

p. 197, add A: TR to distribution of Tournotaris bimaculata (Fabricius, 1787)

p. 198, add PT SB SK to distribution of Stenopelmus rufinasus Gyllenhal, 1835

p. 198, add LU to distribution of Tanysphyrus lemnae (Paykull, 1792) [Caldara]

p. 198, add in synonymy of Tanysphyrus lemnae (Paykull, 1792):

lemnae Fabricius, 1792: 412 (Curculio) [HN]

p. 198, add under "family Erirhinidae, taxa incertae sedis":

genus Hexeria Pascoe, 1885: 228 [DA] type species Hexeria concinna Pascoe, 1885 concinna Pascoe, 1885: 228 A: SD ORR fasciata Marshall, 1938: 163 (Thamnobius)

p. 199, add under Alaocyba: magrinii Fancello \& Leo, 2013: 2 E: IT(Sardegna) p. 199, add:

genus Alaocybites Gilbert, 1956: 55 [DA] type species Alaocybites californicus Gilbert, 1956 egorovi Grebennikov, 2010: 338 A: FE

p. 199, correct year and page for Ferreria marqueti appenina Dieck to 1869: 7

p. 199, place Raymondiellus sbordonii after R. sardous

p. 200, add under Raymondionymus:

antoninii Magrini \& Abbazzi, 2011: 93 E: IT

degiovannii Magrini \& Abbazzi, 2011: 90 E: IT

p. 200, delete (Raymondionymus) after orientalis Hervé

p. 200, add SP to distribution of Raymondionymus perrisi (Grenier, 1864)

p. 200, correct elipsoidalis to ellipsoidalis under Ubychia

p. 200, add under Ubychia: solochaul Struyve, 2010: 203 E: ST

p. 202, transfer Platypus beaveri Browne and its synonyms under synonymy of Platypus levannongi Schedl, 1974 below p. 202, delete flavicornis Kugelann in the synonymy of Platypus cylindrus (Fabricius, 1792), a misidentification of Bostrichus flavicornis Fabricius, 1777 (now in Myoplatypus)

p. 203, add under Platypus:

levannongi Schedl, 1974b: 265 A: TAI ORR

beaveri Browne, 1975: 306

formosanus Niisima \& Murayama, 1925: 217 (Diapus) $[\mathrm{HN}]$

keelungensis Browne, 1985: 294

p. 203, correct Tesserocerinitae to Tesseroceritae

p. 205, delete chloropus Duftschmid, 1825 in synonymy of Hylastes ater (Paykull, 1800); it is a misidentification of Curculio cloropus Linnaeus, 1758 (a synonym of Phyllobius viridicollis (Fabricius, 1792)), mentioned as his source for the name by Duftschmid

p. 206, add IN to distribution of Hylurgops palliatus (Gyllenhal, 1813)

p. 207, add under Hylesinus:

aesculi Kugelann, 1794: 525 (Bostrichus) E: "Preussen"

p. 207, place wachtli orni Fuchs and wachtli wachtli Reitter at the end of the list of species of genus Hylesinus

p. 207, correct spelling, author and page for Hylesinus toranio D'Anthoine to taranio Danthoine and 270 ("70") (toranio is an incorrect subsequent spelling, apparently introduced by Reitter (1916: 278 ) and uncritically followed by Wood \& Bright (1992: 83) in their influential world catalogue); the misspelling toranio should not be conserved since the correct name has been used by other authors, amongst them Lesne (1908) and Russo (1932), and has no meaning, while the original taranio is a phonetic latinization of the French word taragnon, a local Provençal name for this insect

p. 208, add IN to distribution and correct year and page for Pteleobius vittatus Fabricius to 1787: 38

p. 208, delete the comment after abietinus Fabricius in synonymy of Dendroctonus micans (Kugelann, 1794); Opinion 670 in the Bulletin of Zoological Nomenclature, 20: 276-278 (1963) does not mention Bostrichus abietinus; the placement of a species in the Official List (as it is the case for Bostrichus micans) does not eliminate its precedence-competing senior synonyms from nomenclature, but in this case a reversal of precedence under Art. 23.9 by an interested specialist would be welcome, given the economic importance of the species

p. 208, add [HN] to elongatus Herbst in synonymy of Hylurgus ligniperda (Fabricius, 1787)

p. 211, add AUR to distribution of Hyledius cribratus (Blandford, 1896) and add in synonymy: australis Schedl, 1938b: 36 (Phloeosinus) tuberculosus Browne, 1970: 544 (Phloeosinus)

p. 211, add after the type species of genus Phloeosinopsioides Schedl and of its synonym 
Phloeosinopsis Schedl "(= Xylechinus formosanus Schedl, 1935)"

p. 211, add in synonymy of Phloeosinopsioides formosanus (Schedl, 1935):

triseriatus Schedl, 1964: 297 (Phloeosinopsis)

p. 212, add under Phloeosinus:

laricionis Faccoli \& Sidoti, 2013: 98 E: IT(Sicilia)

p. 212, add IN to distribution of Phloeotribus brevicollis (Kolenati, 1846)

p. 212, add IN to distribution of Phloeotribus caucasicus Reitter, 1891

p. 213, correct spelling and page for Phloeotribus scarabaeoides (Bernard) to scaraboeoides and 271

p. 213, delete PL from distribution of Carphoborus cholodkovskyi Spessivtsev, 1916

p. 213, add IN to distribution of Carphoborus pini Eichhoff, 1881

p. 214, add under Polygraphini:

genus Halystus Schedl, 1982: 283 type species Halystus namibiae Schedl, 1982

Phloeographus Wood, 1984: 229 type species Phloeographus mamibiae Wood, 1984 (= Halystus namibiae Schedl, 1982)

bimaculatus Knížek, 2012b: 512 A: YE(Suqutra)

p. 220, add IN to distribution of Ernoporicus caucasicus (Lindemann, 1876)

p. 220, delete [HN] after Bostrichus serratus in synonym of Ernoporicus fagi (Fabricius, 1798), this name has to be declared nomen protectum if desired, since it does not have priority

p. 221, add in synonymy of Hypothenemus birmanus (Eichhoff, 1878):

dubius Schedl, 1971b: 372 (Stylotentus)

p. 224, add JA to distribution of Hypothenemus javanus (Eggers, 1908)

p. 224, place Hypothenemus oblongus Niisima below nobuchii Knížek

p. 224, transfer Hypothenemus taihokuensis Schedl, and its synonym, as synonyms of Hypothenemus tristis (Eichhoff, 1876)

p. 224, add in synonymy of Hypothenemus tristis (Eichhoff, 1876):

cosmoderoides Murayama, 1961: 30 taihokuensis Schedl, 1952b: 63 (Stephanoderes)

p. 224, delete apatoides Eichhoff from synonymy under Hypothenemus tristis and transfer to Dryocoetiops (Eichhoff, 1876)

p. 226, add E: FINR SV to distribution of Trypophloeus dejevi (Stark, 1936)

p. 227, add IN to distribution of Crypturgus numidicus Ferrari, 1867

p. 228, add UK to distribution of Crypturgus subcribrosus Eggers, 1933

p. 230, add in synonymy of Cyrtogenius Strohmeyer, 1910:

Dendrographus Schedl, 1964e: 310 type species Pelicerus pygmaeus Eggers, 1923

Protopityophthorus Schedl, 1973d: 73 type species Protopityophthorus durus Schedl, 1973 (= Pelicerus pygmaeus Eggers, 1923) p. 230, add Ei: IT to distribution of Cyrtogenius luteus (Blandford, 1894)

p. 230, add MA to distribution of Dactylotrypes longicollis (Wollaston, 1864)

p. 231, add CZ to distribution of Dryocoetes himalayensis Strohmeyer, 1908

p. 231, delete Dryocoetes kepongi Schedl, 1953 (already correctly placed under Dryocoetiops)

p. 231, add under Dryocoetiops: apatoides Eichhoff, 1876: 201 (Dryocoetes) A: JA TAI

p. 231, add in synonymy of Dryocoetiops kepongi (Sched1, 1953):

taradakensis Murayama, 1957b:

618

(Pseudopoecilips)

p. 232, add under Pseudothamnurgus: orientalis Schedl, 1978a: 38 (Thamnurgus) A: IS

p. 232, add IN to distribution of Taphrorychus lenkoranus Reitter, 1913

p. 232, transfer Taphrorychus taradakensis (Murayama) under synonymy of Dryocoetiops kepongi (Schedl, 1953)

p. 232, add under genus Thamnurgus:

subgenus Macrothamnurgus Mandelshtam, Petrov \& Korotyaev, 2011: 604 type species Thamnurgus delphinii Rosenhauer, 1856

subgenus Parathamnurgus Mandelshtam, Petrov \& Korotyaev, 2011: 609 type species Thamnurgus caucasicus Reitter, 1887

subgenus Thamnurgus Eichhoff, 1864: 40 type species Bostrichus euphorbiae Küster, 1845

p. 232, transfer Thamnurgus armeniacus Reitter, brylinskyi Reitter and caucasicus Reitter under Thamnurgus subgenus Parathamnurgus

p. 233, transfer pegani Eggers, 1933 as a valid species under Thamnurgus subgenus Parathamnurgus, with distribution $\mathbf{E}$ : AB AR A: TM TR

p. 233, transfer Thamnurgus jemeniae Schedl to Xylocleptes

p. 233, transfer Thamnurgus orientalis Schedl to genus Pseudothamnurgus

p. 233, transfer Thamnurgus kaltenbachii Bach to Thamnurgus subgenus Parathamnurgus, Thamnurgus delphinii Rosenhauer, petzi Reitter and rossicus Alekseev to Thamnurgus subgenus Macrothamnurgus, and the remaining species to Thamnurgus subgenus Thamnurgus

p. 233, add under Xylocleptes: jemeniae Schedl, 1975c: 353 (Thamnurgus) A: YE

p. 234, add SV to distribution of Ips amitinus (Eichhoff, 1872)

p. 234, add BE to distribution of Ips cembrae (Heer, 1836)

p. 234, correct year for Ips sexdentatus (Boerner) to 1776

p. 234, delete PL from distribution of Orthotomicus erosus (Wollaston, 1857)

p. 235, add [HN] to ater Fabricius in synonymy of Pityogenes bidentatus (Herbst, 1783) 
p. 238, add MA to distribution of Scolytus ensifer Eichhoff, 1881

p. 238, add A: TR to distribution of Scolytus koenigi Schevyrew, 1890

p. 239, add IN to distribution of Scolytus pygmaeus (Fabricius, 1787)

p. 240, delete Dermestes geoffroi Goeze, this name does not exist, its use comes from a wrong reading of the Latin expression used by Goeze

p. 242, transfer Ambrosiophilus hunanensis under synonymy of Ambrosiophilus metanepotulus (Eggers, 1939) below

p. 242, add to synonymy of Anisandrus dispar (Fabricius, 1792): dispar Herbst, 1793: 113 (Bostrichus) [HN]

p. 242, correct year and page for Bostrichus brevis and Bostrichus thoracicus to 1795: 288 [in synonymy of Anisandrus dispar (Fabricius, 1792)]

p. 243, add in synonymy of Cyclorhipidion fukiense (Eggers, 1941): ganshoense Murayama, 1952: 16 (Xyleborus)

p. 245, transfer Microperus huangi (Browne) under synonymy of Microperus kadoyamaensis (Murayama, 1934) below

p. 248, transfer Xyleborus ganshoensis Murayama under synonymy of Cyclorhipidion fukiense (Eggers, 1941)

p. 249, add to synonymy of Xyleborus volvulus (Fabricius, 1794): continentalis Eggers, 1920a: 42

p. 249, add Ei: IT to distribution of Xylosandrus compactus (Eichhoff, 1876)

p. 250, add to synonymy of Trypodendron domesticum (Linnaeus, 1758):

limbatum Herbst, 1783: 24 (Bostrichus)

p. 251, delete Apate volvulus Fabricius, 1792 from subfamily Scolytinae, nomina dubia, and transfer to Teredidae in synonym of Teredus cylindricus (A.G. Olivier, 1790) (synonymy by Schaum, 1847: 56)

p. 251, add to "subfamily Scolytinae, nomina dubia": Bostrichus ater Rossi, 1792: 19 E: IT

Bostrichus flavescens Schrank, 1782: 140 (Dermestes) E: GE

Bostrichus fuscus Gmelin, 1790: 1603 E: "Europa" Bostrichus pilosus Gmelin, 1790: 1603 E: "Europa" Bostrichus ruficornis Schrank, 1798: 437 E: GE

p. 251, delete the original genus spelling (Bostrychus) after Bostrichus carinatus Waltl and Bostrichus pilosus Gistel

p. 251, add [HN] to Bostrichus pilosus Gistel, 1831

p. 251, add LU to distribution of Limnobaris dolorosa (Goeze, 1777)

p. 252, add LU to distribution of Limnobaris t-album (Linnaeus, 1758)

p. 252, correct martula to martulus in synonymy of Limnobaris t-album (Linnaeus, 1758), a noun in apposition, invariable

p. 252, add LU to distribution of Aulacobaris chlorizans (Germar, 1824) p. 253, add CY LU MA to distribution of Aulacobaris coerulescens coerulescens (Scopoli, 1763)

p. 253, add LU to distribution of Aulacobaris cuprirostris cuprirostris (Fabricius, 1787)

p. 253, add LU to distribution of Aulacobaris lepidii (Germar, 1824)

p. 253, add under Aulacobaris:

longicollis Faust, 1890e: 473 (Baris) A: MG

p. 254, add LU to distribution of Aulacobaris picicornis picicornis (Marsham, 1802)

p. 254, add under Baris:

achyranthis Marshall, 1938b: 177 A: UP

albosparsa Faust, 1894c: 298 (Baridius) A: UP ORR

carinirostris Ramesha \& Ramamurthy, 2011: 366

A: HP ORR

celosiae G.A.K. Marshall, 1938b: 178 A: UP

p. 254, transfer Baris amanicola Pic, behnei Korotyaev and belovi Korotyaev under genus Melanobaris

p. 254, add LU to distribution of Baris analis analis (Olivier, 1791)

p. 254, add LU to distribution of Baris artemisiae (Panzer, 1794)

p. 254, add [HN] to artemisiae Herbst in synonymy of Baris artemisiae (Panzer, 1794)

p. 255, add under Baris:

marshalli Ramesha \& Ramamurthy, 2011: 371 [HN] A: SD

montana Pajni \& Kohli, 1990: 48 A: HP UP ORR [montanus, incorrect original spelling]

notolineata Pajni \& Kohli, 1990: 51 A: UP [notolineatus, incorrect original spelling]

ramamurthyi Alonso-Zarazaga, nom. nov. [see New Acts] A: NP SD

bimaculata Pajni \& Kohli, 1990: 53 [HN]

p. 255, add in synonymy of Baris egyptus (Kirsch, 1880) [not egypta, it is not an adjective]:

aegypta Hustache, 1938: 66 [unjustified emendation] aegypti Ramesha \& Ramamurthy, 2011: 311 [unjustified emendation]

p. 255, transfer Baris crambephaga Korotyaev \& Gültekin, dzhungarica Korotyaev, edmundi Korotyaev, krausei Korotyaev, maracandica Zaslavskij, nigritarsis Boheman, perlucida Reitter and semistriata Boheman under Melanobaris

p. 255, transfer Baris longicollis Faust under Aulacobaris

p. 256, add under Baris:

subalba Ramesha \& Ramamurthy, 2011: 379 A: HP UP ORR [subalbum, incorrect original spelling]

p. 256, transfer Baris serbica Schultze, steppensis Roubal, suffriani (Hochhuth, 1847), tadzhica Korotyaev and volgensis Zaslavskij under Melanobaris

p. 256, add E: MA to distribution of Cosmobaris discolor (Boheman, 1836)

p. 256, add MA to distribution of Cosmobaris scolopacea (Germar, 1819) 
p. 256, add at end of page:

genus Dinobaris Marshall, 1938: 176 type species Dinobaris longirostris Marshall, 1938 longirostris Marshall, 1938: 176 A: SD

p. 257, add MA to distribution of Eremobaris picturata (Ménétriés, 1849)

p. 258, add MA to distribution of Malvaevora timida timida (Rossi, 1792)

p. 258, add MA to distribution of Maurobaris spoliata (Boheman, 1836)

p. 258, add genus:

genus Mecobaris Marshall, 1936: 221 type species Mecobaris terminaliae Marshall, 1936 squamifera Marshall, 1936: 223 A: UP

subcylindrica Faust, 1898: 326 (Baridius) A: HP ORR

terminaliae Marshall, 1936: 222 A: UP ORR

p. 258, place genus Melitobaris below genus Melanobaris

p. 258, add under Melanobaris:

amanicola Pic, 1905a: 98 (Baris) A: TR (not SY)

behnei Korotyaev, 1988b: 148 (Baris) A: TD

belovi Korotyaev, 1988b: 148 (Baris) A: UZ

crambephaga Korotyaev \& Gültekin, 1999: 141 (Baris) A: TR

dzhungarica Korotyaev, 1988b: 147 (Baris) A: KZ

edmundi Korotyaev, 1988b: 145 (Baris) A: KZ

gulnarae Korotyaev \& Ismailova, 2011: 173 E: ST

krausei Korotyaev, 1988b: 145 (Baris) A: KZ

maracandica Zaslavskij, 1956: 372 (Baris) A: UZ

margaritae Korotyaev \& Friedman, 2011: 170

A: IS

nigritarsis Boheman, 1844: 156 (Baridius) E:

"Caucasus"

perlucida Reitter, 1902b: 192 (Baris) E: AB

semistriata Boheman, 1836: 695 (Baridius) E: AB

BU MO ST UK A: CY KI TR

gimmerthali Hochhuth, 1847: 560 (Baridius)

picitarsis Boheman, 1836: 694 (Baridius)

serbica Schultze, 1897a: 189 [=1897c: 500]

(Baris) E: YU

steppensis Roubal, 1935: 208 (Baris) E: AU SK

suffriani Hochhuth, 1847: 566 (Baridius) E: GG

A: CY

tadzhica Korotyaev, 1988b: 147 (Baris) A: TD

volgensis Zaslavskij, 1956: 373 (Baris) E: ST

p. 258, add FR to distribution of Melanobaris dalmatina (H. Brisout de Barneville, 1870)

p. 259, complete the type species mention of Psilarthroides Morimoto \& Miyakawa, 1985 with (= Baris czerskyi Zaslavskij, 1956)

p. 260, add under Acythopeus:

subgenus Acythopeus Pascoe, 1874: 61 type species Acythopeus tristis Pascoe, 1874

bispinosus Marshall, 1938b: 179 A: UP

p. 260, replace the type species mention of Athesapeuta Faust, 1895 with Baridius subsignatus Motschulsky, 1866 (= Athesapeuta motschulskyi Voss, 1958) p. 263, add reference:

Alziar G. \& Colonnelli E. 2009: [new taxon]. In: Alziar G., Colonnelli E., Lemaire J.-M. \& Makris C. 2009: Sitophilus kakourisi sp. n. from the island of Cyprus (Dryophthoridae: Rhynchophorinae). Snudebiller 10: 112-117.

p. 263, add references:

Alonso-Zarazaga M.A. \& Wang Zh.-L. 2011: [new taxon]. In: Alonso-Zarazaga M.A., Wang Zh.-L. \& Zhang R.-Zh.: A new species of genus Pseudaspidapion Wanat, 1990 (Coleoptera, Apionidae) from China. ZooKeys 120: 41-54.

Arzanov U..G. 2011: Novyj vid roda Brachycerus Billberg, 1820 (Coleoptera: Brachyceridae) iz Sirii. Kavkazskij Ėntomologičeskij Bûlleten’ 7(1): 57-59.

Arzanov Û.G. \& Friedman A.-L.-L. 2012: New species of Brachycerus Olivier (Coleoptera: Brachyceridae) from Turkey. Russian Entomological Journal 21(1): 53-55.

p. 267, correct reference to Bernard, whose name was Pons-Joseph and was the author of the whole book, not of a single chapter, as:

Bernard P-J. 1788: Mémoires pour servir à l'histoire naturelle de la Provence. Vol. 2. Paris, Didot Fils aîné. 559+ [4, unn., Table] +6 [Supplément $]+[1$, Errata] $+3 \mathrm{pl}$.

p. 267, add reference:

BettaV. 1857: [new taxa]. In: Prada T.: Curculioniti dell'agro pavese. Pavia: Fusi, 67 pp.

p. 268, add reference:

Biondi S., Colonnelli E. \& Ringenbach J.-C. 2013: A new species of Cyllorhynchites Voss from Libya (Coleoptera: Rhynchitidae). Journal of Insect Biodiversity 1(11): 1-6.

p. 269, correct reference to Boerner as:

Boerner I.C.H. 1776: Beschreibung eines neuen Insekts, des Dermestes 6-dentatus. Oekonomische Nachrichten der patriotischen Gesellschaft in Schlesien 4(10): 78-80+ pl. VI.

p. 275, correct reference to D'Anthoine as:

Danthoine D.E. 1788: [new taxon]. In: Bernard, P-J.: Mémoires pour servir à l'histoire naturelle de la Provence. Vol. 2. Paris, Didot Fils aîné. 559+ $[4$, unn., Table $]+6$ [Supplément $]+[1$, Errata $]+3$ pl. p. 278 , add reference:

Dieck G. 1869. Diagnosen neuer blinder Käfer aus Süd-Europa und von der Nordküste Maroccos. Merseburg, Author. 8 pp.

p. 283, note the following dating for Fabricius (1798):

Recorded in the Allgemeines Verzeichniss der Bücher, welche in der Frankfurter und Leipziger Ostermesse des 1798 Jahres entweder ganz neu gedruckt, oder sonst verbessert, wieder aufgeleget worden sind, auch inskünftige noch herauskommen sollen, p. 51. The Easter Fair started on 29-IV-1798 (Evenhuis, 2014).

p. 286, correct year for Faust, 1895 b to 1894 c

p. 287, add reference: 
Friedman A.-L.-L. \& Sagiv, A. 2011: Review of the genus Brachycerus Olivier in Israel (Coleoptera: Curculionoidea: Brachyceridae: Brachycerinae). Israel Journal of Entomology 40: 25-70.

p. 290, add reference:

Gilbert E.E. 1956: The Raymondionyminae weevils of California, with a description of a new genus, and several new species (Coleoptera: Curculionidae). The Pan-Pacific Entomologist 32(2): 55-72.

p. 291, add reference:

Grebennikov V.V. 2010: First Alaocybites weevil (Insecta: Coleoptera: Curculionoidea) from the Eastern Palaearctic: a new microphthalmic species and generic relationships. Arthropod Systematics \& Phylogeny 68(3): 331-365.

p. 294, note the following important datings:

Herbst (1793): Recorded in the Allgemeines Verzeichniss der Bücher, welche in der Frankfurter und Leipziger Ostermesse des 1793 Jahres entweder ganz neu gedruckt, oder sonst verbessert, wieder aufgeleget worden sind, auch inskünftige noch herauskommen sollen, p. 54. The Easter Fair started on 21-IV-1793 (Evenhuis, 2014).

Herbst (1795): Recorded in the Allgemeines Verzeichniss der Bücher, welche in der Frankfurter und Leipziger Ostermesse des 1795 Jahres entweder ganz neu gedruckt, oder sonst verbessert, wieder aufgeleget worden sind, auch inskünftige noch herauskommen sollen, $p$. 58. The Easter Fair started on 26-IV-1795 (Evenhuis, 2014).

p. 303, add references:

Knížek M. 2012a: Description of a new species of Aglycyderes (Coleoptera: Belidae: Oxycoryninae). Acta Entomologica Musei Nationalis Pragae 52(2): 503-510.

Knížek M. 2012b: A new species of Halystus from Socotra Island (Coleoptera: Curculionidae: Scolytinae: Polygraphini). Acta Entomologica Musei Nationalis Pragae 52(2): 511-516.

p. 305, add references:

Korotyaev B.A. \& Friedman A.L.L. 2011: A new species of the weevil genus Melanobaris AlonsoZarazaga et Lyal, 1999 (Coleoptera: Curculionidae: Baridinae) from Mt. Hermon in Israel and commentaries on the composition of the genera Melanobaris and Aulacobaris Desbrochers, 1892. Kavkazskij Ėntomologičeskij Bûlleten' 7(2): 169-172.

Korotyaev B.A. \& Ismailova M.Š. 2011: Novyj vid dolgonosikov roda Melanobaris AlonsoZarazaga et Lyal, 1999 (Coleoptera: Curculionidae: Baridinae) iz Vnutrigornogo Dagestana. Kavkazskij Ėntomologičeskij Bûlleten' 7(2): 173-175.

p. 306, please note that Laicharting's (1781) volume 1 was recorded as being sold in the Ostermesse in the Allgemeines Verzeichniss derer Bücher, welche in der Frankfurter und Leipziger Ostermesse des 1781 Jahres entweder ganz neu gedruckt, oder sonst verbessert, wieder aufgeleget worden sind, auch inskünftige noch herauskommen sollen, p. 56. The Easter Fair for 1781 started on 6-V-1781 (Evenhuis, 2014). Additionally, volume 2, which did not contain any weevil but other beetles, and is dated 1784, appeared in fact in 1783, according to Dipauli (1834: 198).

p. 308, add the following references, not included by the editors:

Legalov A. A. 2008a: New species of the tribe Byctiscini (Coleoptera, Rhynchitidae) from Yunnan. Baltic Journal of Coleopterology 8(1): 49-54.

Legalov A. A. 2008b: K izučeniû roda Riedeliops Alonso-Zarazaga et Lyal, 2002 (Coleoptera, Attelabidae, Euopsini) - A taxonomic contribution to our knowledge of the genus Riedeliops AlonsoZarazaga et Lyal, 2002 (Coleoptera, Attelabidae, Euopsini). Evraziatskij èntomologičeskij žurnal 7(3): 213-216.

Legalov A. A. 2008c: To the knowledge of Attelabid-beetles (Coleoptera) of the world fauna. Acta Biologica Universitatis Dangavpilensis 8(2): 193-226.

Legalov A. A. 2009a: New species and new records of the rhynchitid beetles (Coleoptera, Rhynchitidae) from Asia. Amurskij zoologičeskij žurnal 1(1): 30-36.

Legalov A. A. 2009b: Contribution to the knowledge of the world Rhynchitidae (Coleoptera). Baltic Journal of Coleopterology 9(1): 55-88.

Legalov A. A. 2009c: A new species of the genus Involvulus Schrank from China (Coleoptera: Rhynchitidae). Studies and Reports Taxonomical Series 5(1-2): 221-224.

p. 308, add new references:

Legalov A.A. 2010: Three new species of the genus Auletobius (Coleoptera: Rhynchitidae) from China and Vietnam. Studies and Reports Taxonomical Series 6(1-2): 165-170.

Legalov A.A. 2011: New species of the family Rhynchitidae (Coleoptera) from Asia and Africa. Studies and Reports Taxonomical Series 7(1-2): 291-299.

p. 310, add references:

Magrini P. \& Abbazzi P. 2011: Due nuove specie di Raymondionymus della Toscana (Coleoptera, Raymondionymidae). Fragmenta Entomologica 43(1): 89-106.

Mandelshtam M.Û., Petrov A.V. \& Korotyaev B.A. 2011. K poznaniû travânyh koroedov roda Thamnurgus Eichhoff (Coleoptera, Scolytidae). Ėntomologičeskoe Obozrenie 90(3): 595-621.

Mantilleri A. 2011: Nouveaux Microtrachelizini Zimmerman, 1994, du Népal et de Sumatra (Coleoptera, Brentidae). Bulletin de la Société entomologique de France 116(1): 17-24.

Mantilleri A. 2012: Les Eremoxenini ouest-paléarctiques: une taxonomie et une diversité méconnues (Coleoptera, Brentidae). Bulletin de la Société entomologique de France 117(4): 401-409. 
p. 311, add reference:

Marshall G.A.K. 1936: New Indian Curculionidae (Col.). Indian Forest Records 1(11) [1935]: 205231, p1. 1 .

p. 313, add reference:

Muizon J. de 1959: Coléoptères Brenthidae nouveaux du Congo Belge. Revue de zoologie et de botanique africaines 60(1-2): 72-80.

p. 314, correct year for Mulsant, 1858 to 1859 (see explanation below)

p. 314, correct year for Mulsant \& Rey, 1858 to 1859; this volume of the Annales des Sciences Physiques et Naturelles... was recorded as having just appeared by the Bibliographie de la France (2)48(28): 321, dated 9-VII-1859; the Opuscules Entomologiques vol. 9 of the same authors, a reprint of the same text, is to be dated $10-\mathrm{V}-1859$, the date of the dedication to G.R. Waterhouse found at the beginning of the copy in the Library of the MNHN, Paris, even if this work is recorded by the Bibliographie de la France (2)48(47): 547, dated 19-XI-1859, i.e. later than the Annales

p. 318, add reference:

Pajni H.R. \& Kohli S.K. 1990: Current status of some Indian species of genus Baris Germ. and the description of one new genus and three new species (Coleoptera: Curculionidae: Baridinae: Barini). Research Bulletin of the Panjab University Science 41(1-4): 45-59.

p. 319, add reference:

Panzer, G.W.F. 1798b: Faunae Insectorum Germanicae initia oder Deutschlands Insecten. Heft 57. Nürnberg: Felsecker. 24 pp., 24 pls.

p. 325, add reference:

Ramesha B. \& Ramamurthy V. V. 2011: A study on the Baris from India (Coleoptera: Curculionidae). Oriental Insects 45(4): 304-392.

p. 335, add references:

Schedl K.E. 1973d: Scolytidae and Platypodidae of the Archbold Expeditions to New Guinea. 280. Contribution to the morphology and taxonomy of the Scolytoidea. Papua New Guinea Agricultural Journal 24(2): 70-77.

Schedl K.E. 1974b: Borken- und Ambrosiakäfer aus Vietnam (IV). 298. Beitrag zur Morphologie und Systematik der Scolytoidea. Travaux $d u$ Muséum National d'Histoire Naturelle "Grigore Antipa” 14: 261-266.

p. 338, note the following dating for Schoenherr (1847): presented to the Royal Entomological Society of London on 1-XI-1847 (Transactions of the Royal Entomological Society of London, 5, Proceedings: xxvii)

p. 338, add reference:

Schrank F. von Paula. 1782. Kritische Revision des österreichischen Insectenverzeichnisses. Neues Magazin für die Liebhaber der Entomologie 1(2): 135-168. p. 338, note the following dating for Schrank (1798): recorded in the Allgemeines Verzeichniss der Bücher, welche in der Frankfurter und Leipziger Ostermesse des 1798 Jahres entweder ganz neu gedruckt, oder sonst verbessert, wieder aufgeleget worden sind, auch inskünftige noch herauskommen sollen, p. 153. The Easter Fair started on 29-IV-1798 (Evenhuis, 2014).

p. 339, correct year for Senna A. 1893a to 1892 c

p. 344, add reference:

Struyve T. 2010: Description of a new species of Ubychia Rost (Coleoptera: Curculionidae: Raymondionyminae). Koleopterologische Rundschau 80: 203-204.

p. 355, add reference:

Wood S.L. 1984: New generic synonymy and new genera of Scolytidae (Coleoptera). Great Basin Naturalist 44(2): 223-230.

Volume 8

p. 21, line 29, replace Hiroshi with Hiroaki

p. 24, the heading "subfamily Entiminae, taxa incertae sedis" is not listed in the same place in this list as it is in the text, where it appears after tribe Tanymecini on p. 413; its correct placement is as given on the list, corresponding to p. 423 of the text (see correction below)

p. 46, penultimate line, change year to Faust, 1894 to $1984 \mathrm{c}$

p. 47, line 10, replace Alondo with Alonso, misspelling with mistyping, barcleyi with barclayi (the latter is the correct intended name, honouring Maxwell L.V. Barclay, since its origin, having suffered many mistypings in the different versions)

p. 47, replace the entry of genus Orphanobrentus with: genus Nothogaster Lacordaire, 1865: 450 type species Nothogaster paradoxa Lacordaire, 1865 (= Centrophorus curvirostris Chevrolat, 1839) and place Orphanobrentus and Centrophorus as its synonyms

p. 49 , fourth line from bottom, correct 1894 to $1894 \mathrm{c}$

p. 51, add to Curculionidae: Curculioninae: [Caldara] New species

Mecinus dorsalis var. tavaresi Hoffmann, 1958 (p. 1274) is infrasubspecific, since it was described as a variety in a work including subspecies, and was not quoted in the Catalogue. However, a few months before the publication of the Catalogue, it was raised to a valid species by Caldara \& Fogato (2013, p. 78), but erroneously quoting Hoffmann as author, and not meeting the requirements of Art. 16.1. Therefore the following new species is here proposed:

Mecinus tavaresi Caldara \& Fogato sp. nov. The holotype (male) of this taxon is labelled: "Portugal, Soalheria, sur Linaria triornitophora (Cecidie), Tavares / LECTOTYPE Mecinus tavaresi Hoffm. des. R. Caldara 2013" (Muséum National d'Histoire 
Naturelle, Paris, France). The paratypes are labelled as follows: the same as the holotype except "PARALECTOTYPE" (2 exx. Muséum National d'Histoire Naturelle, Paris, France); Portugal-S: 18.4.2006, Faro-Coast, leg. H. Winkelmann (2 exx. coll. H. Winkelmann, Berlin; 2 exx. coll. R. Caldara, Milan); [Spain] Asturie, Villaviciosa, IX.1917 (3 exx., Museo Nacional de Ciencias Naturales, Madrid, Spain). The following red label was added to each specimen "HOLOTYPE (or PARATYPE) Mecinus tavaresi n.sp. des. Caldara \& Fogato, 2015". The description of this new species is that given by Caldara \& Fogato (2013, p. 78).

http://urn:1sid:zoobank.org:act:ED0581C7-820046C5-B138-79EAB0ADB23A

p. 52, add:

Sibinia attalica var. judea Pic, 1901, syn. nov. of Sibinia lyrata Faust, 1889. Based on the original description. [Caldara]

p. 55, line 6, correct ochromaculatus to octomaculatus

p. 56, add to Curculionidae: Curculioninae:

\section{Erroneous reversal of precedence}

Caldara (2008) declared Rhinusa antirrhini (Paykull, 1800) a nomen protectum and Rhinusa noctis (Herbst, 1795) a nomen oblitum. This fact was reflected in the treatment used on p. 140 of the Catalogue. However, unknown then to the author and the coordinator, the latter name has been used at least twice as a valid name for a species during the $20^{\text {th }}$ century: Champion (in Champion \& Chapman, 1904) and Léon-Hilaire (1924). The case has to be referred to the Commission under Art. 23.10.

\section{Homonyms}

Archarius (Archarius) parvus (Kwon \& Lee, 1990) (originally in Balanobius) is a secondary homonym of Archarius (Archarius) parvus (Hong \& Wang, 1987) (originally in Longifistulia), a fossil species.

Curculio (Curculio) helleri Pelsue \& Zhang, 2002 is a secondary homonym of Curculio (Curculio) helleri (Voss, 1932) (originally in Balaninus).

\section{New combinations}

Cionus affinis (Brahm, 1790), comb. nov. from Curculio.

Curculio helleri (Voss, 1932), comb. nov. from Balaninus

Pseudopoophagus constricticollis (Kojima \& Morimoto, 1993), comb. nov. from Apionodes

\section{New replacement name}

Archarius (Archarius) kwonleeanus AlonsoZarazaga, nom. nov. for Archarius (Archarius) parvus (Kwon \& Lee, 1990) (non Archarius (Archarius) parvus (Hong \& Wang, 1987), a fossil species). Named after the authors of the replaced specific name. The replacement name is an adjective.

Curculio (Curculio) zhangianus Alonso-Zarazaga, nom. nov. for Curculio (Curculio) helleri Pelsue \& Zhang, 2002 (non Curculio (Curculio) helleri
(Voss, 1932)). Named after Zhang Runzhi, colleague and friend, one of the authors of the replaced specific name. The replacement name is an adjective.

\section{Reversal of precedence}

Anthonomus incurvus (Panzer, 1795) was given precedence over Anthonomus humeralis (Panzer, 1795) by Panzer himself (1796: no. 17) -in which he was followed by Schoenherr (1835: 342-343) - when he used the former as the valid name and the second as an invalid synonym of the former, acting thus as the First Reviser. $A$. incurvus has been in use during the $20^{\text {th }}$ century (e.g. Kirchner, 1906: 520; Pierce, 1918: 23; etc.) as the valid name for the species and does not meet the requirements of Art. 23.9.1.1 to be declared a nomen oblitum. Consequently, in application of the Principle of Precedence, it is here reinstated as the valid name for this species.

p. 56, add:

\section{Curculionidae: Curculioninae}

M.A. Alonso-Zarazaga \& R. Caldara

\section{Reversal of precedence}

Curculio resinae Fabricius, 1792b: 447 was proposed as a new name for the wrongly identified Curculio beccabungae sensu Fabricius, 1787 (non Linnaeus, 1760) and was made available by a short description ("Differt omnino a $C$. Resinae, quem olim Beccabungae vocavi. Corpus duplo minus, nigrum coleoptris ante apicem rufis."). This Fabrician name has been overlooked by all catalogues and even by Sherborn's "Index Animalium". Schoenherr (1835: 345) synonymized $C$. beccabungae sensu Fabricius, 1787 with Anthonomus varians (Paykull, 1792), a primary homonym (non Olivier, 1791), now Anthonomus phyllocola (Herbst, 1795).

Based on this information, and for the sake of stability, we have decided to declare Herbst's species a nomen protectum. Curculio resinae Fabricius, 1792 meets the requirements of Art. 23.9.1.1 (and is here declared a nomen oblitum) and Curculio phyllocola Herbst, 1795 (now Anthonomus phyllocola) meets those of Art. 23.9.1.2 (and is here declared a nomen protectum). In accordance with Art. 23.9.2, we hereby consider that the younger name is valid for this species and give evidence that the conditions of Art. 23.9.1.2 are met by quoting the following references: Abbazzi \& Maggini (2009); Abbazzi \& Osella (1992); Abbazzi et al. (1995); Alonso-Zarazaga \& Lyal (1999); Alonso-Zarazaga et al. (2013); Benedikt et al. (2010); Borovec et al. 2003; Braunert (2009); Caldara (2013); Caldara et al. (2014); Cholewicka-Wiśniewska (1994); Colonnelli (2003); Dieckmann (1988); Germann (2010); Lindelow \& Björkman (2001); 
Mazur (2003); Pelletier (2005); Podlussány (2001); Poiras (1998); Rheinheimer \& Hassler (2010); Schott (1999); Silfverberg (1979); Telnov (2004); Wanat (1994); Wanat \& Mokrzycki (2005).

p. 57. Colonnelli, in his section on Reversal of precedence, listed Curculio floralis Olivier, 1790 (correctly 1791) as a junior synonym of Curculio napobrassicae Bjerkander, 1780 (itself a synonym of Curculio obstrictus Marsham, 1802). Following this, he declared a reversal of precedence under Art. 23.9.2 identifying both names nomina oblita in favour of Curculio obstrictus Marsham, 1802. However, this declaration of nomen oblitum for Curculio floralis Olivier, 1791 is incorrect, since C. floralis is an unnecessary replacement name for Curculio floriger Geoffroy, 1785, in turn a synonym of Cleopomiarus plantarum (Germar, 1824). On page 56, I had declared Curculio floralis a nomen oblitum against Cionus plantarum Germar, 1824, following the correct synonymy. This understanding is reflected on p. 136 of the Catalogue and the change proposed below for p. 184 .

p. 64, the two lines dealing with the replacement name Polydrusus (Polydrusus) korbianus Yunakov should have been deleted by the Editors; at the time of editing, the name Polydrusus korbi Reitter, 1908 had already been demonstrated to be the same as Chaerodrys korbi Stierlin, 1888 (an Eastern Mediterranean species) and Polydrusus korbi Stierlin, 1890 (a Spanish species) had been replaced with Polydrusus tinauti AlonsoZarazaga, 2013; Yunakov's replacement name did not appear in the main text of the Catalogue

p. 74, delete the antepenultimate line, which duplicates the preceding one

p. 75 , add to New combinations :

Otiorhynchus mucronatus (Paykull, 1792), comb. nov. from Curculio

p. 81 , line 10, replace "latter name" with "the latter name"

p. 82, add, under Synonyms:

Curculio prasinus Olivier, 1791, syn. nov. of Phyllobius (Metaphyllobius) pomaceus Gyllenhal, 1834. Olivier's (1781) description corresponds to a Phyllobius and Olivier himself (1807, p. 413) placed it in synonymy of Curculio alneti Fabricius, 1792 (a synonym of $P h$. pomaceus), in which he was followed by Schoenherr (1834b: 438). A search for the type material in Olivier's collection conducted by Hélène Perrin and me in 2012 had no success. This species was used as valid in the genus Polydrusus by Dalla Torre et al. (1936: 102) in the Junk Catalogue, perhaps in confusion with Polydrusus prasinus Reitter, 1899, which is mentioned in its synonymy, and replacing Polydrusus planifrons Gyllenhal, 1834, which is reinstated here. In the Junk Catalogue, C. prasinus
Olivier was mentioned twice, one as a valid species in Polydrusus (Dalla Torre et al., 1936: 102) and a second as a synonym of Phyllobius urticae by Lona (1938: 493). Since treating Phyllobius prasinus (Olivier) as valid will be most confusing, I will refrain from doing so here and will apply the name in current usage.

p. 90, line3, replace $C$. ahenus with Thylacites ahenus p. 92, lines 35 and 37, correct Tropiphurus to Tropiphorus p. 93, lines 12 and 13, correct arealotus to areolatus p. 93, add before Donus ferganicus: [Skuhrovec]

Donus diversisquamosus (Legalov, 2012), comb. nov. from Asiodonus (this and the following species are relatives of species which have already been transferred to the genus Donus by Skuhrovec (2013) following the synonymy of the genus Asiodonus, and these overlooked species are following the placement of their relatives)

p. 93, add at bottom: [Skuhrovec]

Donus knutelskyi (Legalov, 2012), comb. nov. from Asiodonus

p. 94, add before Donus rugulosus: [Skuhrovec]

Donus potanini (Legalov, 2012), comb. nov. from Asiodonus

p. 94, add before Donus solidus: [Skuhrovec]

Donus shokhrini (Legalov, 2012), comb. nov. from Asiodonus

p. 94, add after Donus solidus: [Skuhrovec]

Donus streltzovi (Legalov, 2012), comb. nov. from Asiodonus

p. 94, line 8, replace Donus taurica with Brachypera (Brachypera) taurica and transfer after B. (B.) scapularis on p. 93 [Skuhrovec]

p. 94, add after Donus transiliensis: [Skuhrovec]

Donus tshernyshevi (Legalov, 2012), comb. nov. from Asiodonus

p. 96, add:

\section{Curculionidae: Hyperinae} J. Skuhrovec

\section{Comments}

Legalov (2012b, 2012c) published new findings from Russia and also other regions in Asia. In these two papers, there are really interesting data, but some of them are controversial because they are not credible, e.g. Hypera libanotidis (Reitter, 1869), probably an extinct endemic from one locality in Moravia (CZ), is presented as a species known from the Eastern part of Russia, without any comment. From this point of view, these new faunistic data will not be included until these specimens can be studied.

p. 96, add:

\section{Curculionidae: Hyperinae M. A. Alonso-Zarazaga}

\section{Reversal of precedence}

Alonso-Zarazaga (2008: 28) declared Rhynchaenus posticus Gyllenhal, 1813 a nomen protectum against Curculio fasciolatus Geoffroy, 1785, which was 
declared a nomen oblitum. However, in this article, another senior synonym, Curculio denigratus Panzer, 1790, was overlooked. Curculio denigratus Panzer, 1790 meets the requirements of Art. 23.9.1.1 (and is here declared a nomen oblitum) and Rhynchaenus posticus Gyllenhal, 1813 (now Hypera postica) meets those of Art. 23.9.1.2 (and is here declared a nomen protectum). In accordance with Art.23.9.2, I hereby consider that the junior name is valid for this species and give evidence that the conditions of Art. 23.9.1.2 are met by quoting the same references that were quoted in Alonso-Zarazaga (2008, p. 28). p. 102, add:

\section{Curculionidae: Lixinae: Cleonini M.A. Alonso-Zarazaga}

\section{Infrasubspecific names}

Leucochromus lehmanni var. consobrinus Faust, 1904, described in the same work as Epilectus lehmanni var. consobrinus, is a colour variety without type locality, and consequently, it is considered infrasubspecific. It is available as Leucochromus consobrinus Ter-Minasian, 1972.

\section{New synonym}

Curculio alternans Hellwig, 1795 has a demonstrable minimum of ten days priority (probably more) over Curculio alternans Herbst, 1795. Herbst based his description on the same specimens kept in Hellwig's collection, so both names are objective synonyms. This synonymy affects only the author's name, so I prefer to apply the Principle of Priority.

\section{New combination}

Mecaspis alternans (Hellwig, 1795), comb. nov. from Curculio

p. 103 , line 8 , correct "shaw" to "show"

p. 103, line 32, correct "orginally" to "originally"

p. 110, add:

\section{Curculionidae: Lixinae: Lixini \\ M. A. Alonso-Zarazaga}

\section{Homonymy and replacement name}

Lixus tricolor Capiomont, 1876 is a secondary homonym of L. tricolor (Scopoli, 1771). Capiomont's name has been scarcely mentioned and a reversal of precedence cannot be applied. Consequently, it is here replaced with Lixus trichromus Alonso-Zarazaga, nom. nov.

\section{New synonyms}

Curculio phellandrii Linnaeus, 1764, syn. nov. of Lixus paraplecticus (Linnaeus, 1758)

Curculio teres Hellwig, 1795, syn. nov. of Larinus (Larinomesius) scolymi (Olivier, 1807)

p. 117, add LT LU to distribution of Acalyptus carpini (Fabricius, 1792) [Silfverberg, Caldara]

p. 117, add CY to distribution of Derelomus chamaeropis (Fabricius, 1798)

p. 118, add under genus Ancylocnemis Marshall the following line:

subgenus Ancylocnemis Marshall, 1920: 387 type species Ancylocnemis fasciculata Marshall, 1920 p. 118, add LU to distribution of Anoplus plantaris (Naezen, 1794) [Caldara]

p. 118, add LU to distribution of Anoplus roboris Suffrian, 1840 [Caldara]

p. 118, add LU to distribution of Anoplus setulosus Kirsch, 1870 [Caldara]

p. 119, add [NP] to Anthonomus (Anthomorphus) phyllocola (Herbst, 1795) and add in synonymy: [Alonso-Zarazaga \& Caldara] resinae Fabricius, 1792b: 447 (Curculio) [NO]

p. 119, add LU to distribution of Anthonomus (Anthomorphus) phyllocola (Herbst, 1795) [Caldara]

p. 119, add NR to distribution of Anthonomus (Anthonomus) brunnipennis Curtis, 1840 [Silfverberg]

p. 119, add LU to distribution of Anthonomus (Anthonomus) chevrolati chevrolati Desbrochers des Loges, 1868 [Caldara]

p. 119, add LU to distribution of Anthonomus (Anthonomus) conspersus Desbrochers des Loges, 1868 [Caldara]

p. 120, replace Anthonomus (Anthonomus) humeralis (Panzer, 1795) with Anthonomus (Anthonomus) incurvus (Panzer, 1795), and place the former name as a synonym of the latter

p. 120, add LT to distribution of Anthonomus (Anthonomus) incurvus (Panzer, 1795) [Silfverberg]

p. 120, add in synonymy of Anthonomus (Anthonomus) pedicularius (Linnaeus, 1758) the following nominal species:

fuscus Goeze, 1777: 391 (Curculio) scutellatus Geoffroy, 1785: 131 (Curculio) fuscus Gmelin, 1790: 1772 (Curculio) [HN]

p. 120, add FI LU to distribution of Anthonomus (Anthonomus) pomorum (Linnaeus, 1758) [Silfverberg, Caldara]

p. 120, add LU to distribution of Anthonomus (Anthonomus) pyri Gyllenhal, 1835 [Caldara]

p. 120, add LU to distribution of Anthonomus (Anthonomus) rubi (Herbst, 1795) [Caldara]

p. 121, add LU to distribution of Anthonomus (Anthonomus) rufus Gyllenhal, 1835 [Caldara]

p. 121, add LU to distribution of Anthonomus (Anthonomus) sorbi Germar, 1821 [Caldara]

p. 121, add LT to distribution of Anthonomus (Anthonomus) undulatus Gyllenhal, 1835 [Silfverberg]

p. 121, add LU to distribution of Anthonomus (Furcipus) rectirostris (Linnaeus, 1758) [Caldara]

p. 121, add under Anthonomus subgenus Persexarthrus: fraudulentus Voss, 1960b: 150 (Anthomorphus) A: AF

p. 122, add LU to distribution of Brachonyx pineti (Paykull, 1792) [Caldara]

p. 122, add CT LU SZ to distribution of Bradybatus (Bradybatus) kellneri Bach, 1854 [Caldara, Alonso-Zarazaga]

p. 122, add LU to distribution of Bradybatus (Nothops) fallax Gerstacker, 1860 [Caldara] 
p. 123, add LU to distribution of Cionus alauda (Herbst, 1784) [Caldara]

p. 123, add LU to distribution of Cionus ganglbaueri Wingelmüller, 1914

p. 123, add LU to distribution of Cionus hortulanus (Geoffroy, 1785) [Caldara]

p. 124, add FI LT LU to distribution of Cionus nigritarsis Reitter, 1904 [Silfverberg, Caldara]

p. 124, add LU to distribution of Cionus olens (Fabricius, 1792) [Caldara]

p. 124, add LU and NARi to distribution of Cionus scrophulariae (Linnaeus, 1758) [Caldara, Alonso-Zarazaga]

p. 124, delete [NP] after Cionus thapsus thapsus (Fabricius, 1792)

p. 124, delete assimilis Harrer in the synonymy of Cionus thapsus thapsus (Fabricius, 1792) (it has been suppressed in Opinion 1529, ICZN 1989)

p. 124, add LU to distribution of Cionus thapsus thapsus (Fabricius, 1792) [Caldara]

p. 124, add LU to distribution of Cionus tuberculosus (Scopoli, 1763) [Caldara]

p. 124, add under Cionus, nomen dubium: affinis Brahm, 1790: 60 (Curculio) [HN] E: GE

p. 124, add LU to distribution of Cleopus pulchellus (Herbst, 1795) [Caldara]

p. 125, add LU to distribution of Cleopus solani (Fabricius, 1792) [Caldara]

p. 125, add LU to distribution of Stereonychus fraxini (De Geer, 1775) [Caldara]

p. 125, correct "un ecessary" to "unnecessary" after geeri Gmelin [in synonymy of Stereonychus fraxini (DeGeer, 1775)

p. 125, add LU to distribution of Archarius crux (Fabricius, 1777) [Caldara]

p. 126, add under Archarius subgenus Archarius: kwonleeanus Alonso-Zarazaga, nom. nov. [see New Acts] A: FE SC

parvus Kwon \& Lee, 1990: 99 (Balanobius) [HN] ziliolii Diotti \& Caldara, 2013: 252 E: IT SZ

p. 126, delete parvus Kwon \& Lee, 1990 (transferred in synonymy of Archarius kwonleeanus)

p. 126, add FI LU to distribution of Archarius (Archarius) pyrrhoceras (Marsham, 1802) [Silfverberg, Caldara]

p. 126, add LU and NARi to distribution of Archarius (Archarius) salicivorus (Paykull, 1792) [Caldara, Alonso-Zarazaga]

p. 126, add TAI to distribution of Curculio (Curculio) alboscutellatus (Roelofs, 1875)

p. 127, add under Curculio subgenus Curculio: choui Notsu, 2013: 300 A: TAI

p. 127, add TAI to distribution of Curculio (Curculio) camelliae (Roelofs, 1875)

p. 127, add LU to distribution of Curculio (Curculio) elephas (Gyllenhal, 1835) [Caldara]

p. 128, add under Curculio subgenus Curculio: fulvirostris Heller, 1927: 188 (Balaninus) A: SD fulvus Marshall, 1938b: 164 (Balaninus) A: UP ORR gwangneungensis Kwon \& Lee, 1981: 50 A: SC helleri Voss, 1932a: 68 (Balaninus) A: SCH

longigas Kwon \& Lee, 1981: 50 A: SC

p. 128, add LU to distribution of Curculio glandium Marsham, 1802 [Caldara]

p. 128, delete helleri Pelsue \& Zhang, 2002 (transferred in synonymy of Curculio zhangianus below)

p. 128, delete hirashimai Morimoto, 1981 (transferred to Indocurculio below)

p. 128, delete kojimai Morimoto, 1960 (transferred in synonymy of Curculio sauteri below)

p. 129, add LU to distribution of Curculio nucum Linnaeus, 1758 [Caldara]

p. 129, add LU to distribution of Curculio pellitus (Boheman, 1843) [Caldara]

p. 129, add under Curculio subgenus Curculio: punctum Marshall, 1938b: 165 (Balaninus) A: UP roridus Marshall, 1938b: 166 (Balaninus) A: UP

p. 129, add LU NARi to distribution of Curculio (Curculio) rubidus (Gyllenhal, 1835) [Caldara, Alonso-Zarazaga]

p. 129, add JA to distribution of Curculio (Curculio) sauteri (Heller, 1927) and add in synonymy: kojimai Morimoto, 1960b: 99

p. 130, add to Curculio subgenus Curculio: subfiguratus Voss, 1960b: 126 A: AF

p. 130, add GE to distribution of Curculio (Curculio) vicetinus Cussigh, 1989

p. 130, add LU to distribution of Curculio (Curculio) venosus venosus (Gravenhorst, 1807) [Caldara]

p. 130, correct page for tenuirostris Fabricius, 1781a to 180 [in synonymy of Curculio (Curculio) villosus (Fabricius, 1781)]

p. 130, add under Curculio subgenus Curculio: uedai Notsu, 2013: 298 A: TAI

zhangianus Alonso-Zarazaga, nom. nov. [see New Acts] A: FUJ

helleri Pelsue \& Zhang, 2002: 23 [HN]

p. 130, add below genus Curculio:

genus Indocurculio Pajni, Singh \& Gandhi, 1994: 156 type species Indocurculio minutus Pajni, Singh \& Gandhi, 1994

hirashimai Morimoto, 1981a: 115 (Curculio) A: JA TAI

p. 131, add under Carponinus subgenus Carponinus: castaneus Notsu, 2013: 301 A: TAI elegantulus Morimoto, 1965: 44 A: TAI

p. 130, add LU to distribution of Dorytomus (Dorytomus) dejeani Faust, 1883 [Caldara]

p. 130, add LU to distribution of Dorytomus (Dorytomus) dorsalis (Linnaeus, 1758) [Caldara]

p. 132, add LU to distribution of Dorytomus (Dorytomus) filirostris (Gyllenhal, 1835) [Caldara]

p. 132, add LU to distribution of Dorytomus (Dorytomus) hirtipennis Bedel, 1884 [Caldara]

p. 132, add EN LU to distribution of Dorytomus (Dorytomus) ictor (Herbst, 1795) [Silfverberg, Caldara] 
p. 132, add LU to distribution of Dorytomus (Dorytomus) longimanus (Forster, 1771) [Caldara]

p. 132, add LU to distribution of Dorytomus (Dorytomus) melanophthalmus (Paykull, 1792) [Caldara]

p. 133, add LU to distribution of Dorytomus (Dorytomus) rubrirostris (Gravenhorst, 1807) [Caldara]

p. 133, add LU to distribution of Dorytomus (Dorytomus) rufatus rufatus (Bedel, 1888) [Caldara]

p. 133, add LU to distribution of Dorytomus (Dorytomus) schoenherri schoenherri Faust, 1883 [Caldara]

p. 133, add LU to distribution of Dorytomus (Dorytomus) taeniatus (Fabricius, 1781) [Caldara]

p. 133, add LU to distribution of Dorytomus (Dorytomus) tortrix (Linnaeus, 1760) [Caldara]

p. 133, add in synonymy of Dorytomus (Dorytomus) tortrix (Linnaeus, 1760) the following two names (the synonymy is by Schrank (1782) himself): alneti Schrank, 1781: 115 (Curculio) latro Schrank, 1781: 115 (Curculio)

p. 134, add LU to distribution of Dorytomus (Dorytomus) tremulae (Fabricius, 1787) [Caldara]

p. 134, add LU to distribution of Ellescus bipunctatus (Linnaeus, 1758) [Caldara]

p. 134, add [unjustified RN] to unipunctatus Olivier, 1791 in synonymy of Ellescus bipunctatus (Linnaeus, 1758)

p. 134, add LT to distribution of Ellescus infirmus (Herbst, 1795) [Silfverberg]

p. 134, add BEI to distribution of Ellescus languidus Faust, 1882

p. 134, add LU to distribution of Ellescus scanicus (Paykull, 1792) [Caldara]

p. 134, add under Pseudopoophagus: constricticollis Kojima \& Morimoto, 1993: 88 (Apionodes) A: TAI

p. 135, correct original genus to Miaromimus for Cleopomiarus dictamnophilus (Zherikhin, 1996)

p. 136, add LU to distribution of Cleopomiarus graminis (Gyllenhal, 1813) [Caldara]

p. 136, add NT to distribution of Cleopomiarus jakowlewi (Faust, 1895) [Silfverberg]

p. 136, correct year for scutellaris H. Brisout de Barneville to 1866 [in synonymy of Cleopomiarus longirostris longirostris (Gyllenhal, 1838)]

p. 136, correct year for Cleopomiarus meridionalis (H. Brisout de Barneville) to 1863

p. 136, add [NO] to floralis Olivier, 1791 in synonymy of Cleopomiarus plantarum (Germar, 1824)

p. 136, add in synonymy of Cleopomiarus plantarum (Germar, 1824):

nigrostriatus Petagna, 1792: 221 (Curculio) [HN]

p. 136, correct year for Cleopomiarus salsosae $(\mathrm{H}$. Brisout de Barneville) to 1863

p. 136, correct author, year and page of Gymnetron beccabungae to Linnaeus, 1760: 179 p. 137, add LU to distribution of Gymnetron melanarium (Germar, 1821) [Caldara]

p. 137, add GE SZ to distribution of Gymnetron rotundicolle Gyllenhal, 1838 [Caldara, Alonso-Zarazaga]

p. 137, add WS to distribution of Gymnetron terminassianae Smreczyński, 1975

p. 137, add LT LU to distribution of Gymnetron veronicae (Germar, 1821) [Silfverberg, Caldara]

p. 137, add LU to distribution of Gymnetron villosulum Gyllenhal, 1838 [Caldara]

p. 138, add LT to distribution of Mecinus collaris (Germar, 1821) [Silfverberg]

p. 138, correct page for pyrenaeus H. Brisout de Barneville, 1862 to 629 [in synonymy of Mecinus elongatus (H. Brisout de Barneville, 1862)]

p. 138, correct page for Mecinus haemorrhoidalis (H. Brisout de Barneville, 1862) to 629

p. 138, add LU to distribution of Mecinus heydenii Wencker, 1866 [Caldara]

p. 138, add LU to distribution of Mecinus janthinus (Germar, 1821) [Caldara]

p. 138, add LU NR to distribution of Mecinus labilis (Herbst, 1795) [Caldara, Silfverberg]

p. 139, add LU to distribution of Mecinus pascuorum (Gyllenhal, 1813) [Caldara]

p. 139, add LU to distribution of Mecinus pyraster (Herbst, 1795) [Caldara]

p. 139, add under Mecinus: [Caldara]

tavaresi Caldara \& Fogato, sp. nov. [see New Acts above] E: PT SP

p. 140, add EN LA LT to distribution of Miarus campanulae (Linnaeus, 1767) [Silfverberg]

p. 140, correct year and page for Rhinusa algirica (H. Brisout de Barneville) to 1867: 64

p. 140, add LU to distribution of Rhinusa antirrhini (Paykull, 1800) [Caldara]

p. 141, add LU to distribution of Rhinusa asellus (Gravenhorst, 1807) [Caldara]

p. 141, correct year for Rhinusa brondelii (H. Brisout de Barneville) to 1863

p. 141, add LT to distribution of Rhinusa collina (Gyllenhal, 1813) [Silfverberg]

p. 141, add CY to distribution of Rhinusa emmrichi (Bajtenov, 1979)

p. 141, correct year for Rhinusa lanigera (H. Brisout de Barneville) to 1863

p. 141, add LU SZ NARi to distribution of Rhinusa linariae (Panzer, 1795) [Caldara, Alonso-Zarazaga]

p. 141, delete [NP] after Rhinusa linariae (Panzer, 1795)

p. 141, delete Curculio curvirostris in synonymy of Rhinusa linariae (Panzer, 1795), a misidentification of Curculio curvirostris Fabricius, 1781, unavailable

p. 142, add DE to distribution of Rhinusa melas (Boheman, 1838) [Silfverberg]

p. 142, add LT SV NARi to distribution of Rhinusa neta (Germar, 1821) [Silfverberg, Alonso-Zarazaga]

p. 142, add SZ to distribution of Rhinusa pilosa (Gyllenhal, 1838) [Caldara] 
p. 142, add DE LA LT LU to distribution of Rhinusa tetra (Fabricius, 1792) [Silfverberg, Caldara]

p. 142, add SZ to distribution of Rhinusa vestita (Germar, 1821) [Caldara]

p. 142, add under Acallopistus: vellicosus Schoenherr, 1826: 250 A: PA YE AFR ORR maculithorax Hustache, 1929b: 508 senegalensis Hustache, 1932e: 69

The record of $A$. abutilonis Marshall may refer to this species.

p. 143, add under Drepanoscelus: gardneri Marshall, 1938b: 161 A: UP

p. 145, add LT LU NR SV SZ to distribution of Isochnus foliorum (O.F. Müller, 1776) [Silfverberg, Caldara]

p. 145, add LU to distribution of Isochnus sequensi (Stierlin, 1894) [Caldara]

p. 145, add to synonymy of Orchestes (Alyctus) calceatus (Germar, 1821): pubescens Gyllenhal, 1835a: 495

quinquemaculatus Chevrolat, 1867: 1xvi

p. 145, add NR to distribution of Orchestes (Alyctus) calceatus (Germar, 1821) [Silfverberg]

p. 145, add DE EN FI LA LT LU NR NT SV SZ to distribution of Orchestes (Alyctus) rusci (Herbst, 1795) [Silfverberg, Caldara]

p. 145, delete salicis Schrank from synonymy of Orchestes (Alyctus) rusci (Herbst, 1795); a misidentification of Tachyerges salicis (Linnaeus, 1758)

p. 145, delete pubescens Gyllenhal and quinquemaculatus Chevrolat from synonymy of Orchestes (Alyctus) testaceus (O.F. Müller, 1776)

p. 145, add LU to distribution of Orchestes (Alyctus) testaceus (O.F. Müller, 1776) [Caldara]

p. 146, correct NAR to NARi in distribution of Orchestes (Orchestes) alni (Linnaeus, 1758)

p. 146, add LU to distribution of Orchestes (Orchestes) betuleti (Panzer, 1795) [Caldara]

p. 146, add LU to distribution of Orchestes (Orchestes) erythropus Germar, 1821 [Caldara]

p. 146, add LT LU NARi to distribution of Orchestes (Orchestes) fagi fagi (Linnaeus, 1758) [Silfverberg, Caldara]

p. 146, add LU to distribution of Orchestes (Orchestes) hortorum (Fabricius, 1792) [Caldara]

p. 147, add LU to distribution of Orchestes (Orchestes) jota (Fabricius, 1787) [Caldara]

p. 147, add LU to distribution of Orchestes (Orchestes) pilosus (Fabricius, 1781) [Caldara]

p. 147, add LU to distribution of Orchestes (Orchestes) quercus (Linnaeus, 1758) [Caldara]

p. 148, correct original genus to Orchestes for Pseudorchestes asterici Hustache

p. 148, add under Pseudorchestes: [Caldara, Alonso-Zarazaga]

convexus Korotyaev, 2011b: 247 E: ST A: KI KZ olgae Korotyaev, 2011b: 243 E: KZ p. 148, add LU to distribution of Pseudorchestes ermischi (Dieckmann, 1958) [Caldara]

p. 149, add under Pseudorchestes: [Caldara, Alonso-Zarazaga]

tschernovi Korotyaev, 2011b: 245 A: MG

p. 149, add LU SZ to distribution of Rhamphus oxyacanthae (Marsham, 1802) [Caldara]

p. 149, add LU to distribution of Rhamphus pulicarius (Herbst, 1795) [Caldara]

p. 149, add LU to distribution of Rhamphus subaeneus Illiger, 1807 [Caldara]

p. 150, add LU to distribution of Tachyerges decoratus (Germar, 1821) [Caldara]

p. 150, add LU to distribution of Tachyerges pseudostigma (Tempère, 1982) [Caldara]

p. 150, add LU to distribution of Tachyerges salicis (Linnaeus, 1758) [Caldara]

p. 150, add LU to distribution of Tachyerges stigma (Germar, 1821) [Caldara]

p. 151, add MA to distribution of Sharpia rubida (Rosenhauer, 1856)

p. 151, add LT to distribution of Smicronyx (Smicronyx) coecus (Reich, 1797) [Silfverberg]

p. 152, add LU to distribution of Smicronyx jungermanniae (Reich, 1797) [Caldara]

p. 152, add IT LU to distribution of Smicronyx nebulosus Tournier, 1874 [Caldara]

p. 152, add CY to distribution of Smicronyx pauperculus Wollaston, 1864

p. 153, correct author and year for Pachytychius basimaculatus with Voss, 1964 [Caldara]

p. 154, add LU to distribution of Pachytychius haematocephalus (Gyllenhal, 1835) [Caldara]

p. 154, add LU to distribution of Pachytychius sparsutus (Olivier, 1907) [Caldara]

p. 155, add LU to distribution of Orthochaetes setiger (Beck, 1817) [Caldara]

p. 156, add LU to distribution of Pseudostyphlus pillumus (Gyllenhal, 1835) [Caldara]

p. 157, add CZ ST to distribution of Lignyodes (Lignyodes) bischoffi (Blatchley, 1916)

p. 157, add LU to distribution of Lignyodes enucleator (Panzer, 1798) [Caldara]

p. 160, add as a synonym of Sibinia (Sibinia) lyrata Faust, 1889: [Caldara] judea Pic, 1901f: 82

p. 160, delete cana Olivier, 1807 in synonymy of Sibinia (Sibinia) pellucens (Scopoli, 1772) (a later use of Curculio canus Herbst, 1784)

p. 160, add LU to distribution and correct year for Sibinia (Sibinia) pellucens (Scopoli) to 1771 [Caldara, Alonso-Zarazaga]

p. 160, add LA LU to distribution of Sibinia (Sibinia) phalerata Gyllenhal, 1835 [Silfverberg, Caldara]

p. 160, add the name primita Herbst, 1795 (Curculio) and replace the names signata Panzer and gyllenhali Desbrochers des Loges in synonymy with it as previously considered (Caldara et al., 2014) [Caldara] 
p. 160, add LU to distribution of Sibinia (Sibinia) pyrrhodactyla (Marsham, 1802) [Caldara]

p. 160, add LA to distribution of Sibinia (Sibinia) subelliptica Desbrochers des Loges, 1873 [Silfverberg]

p. 161, add LU to distribution of Sibinia (Sibinia) viscariae (Linnaeus, 1761) [Caldara]

p. 163, add LU to distribution of Tychius (Tychius) aureolus Kiesenwetter, 1852 [Caldara]

p. 163, add DE LU to distribution of Tychius (Tychius) breviusculus Desbrochers des Loges, 1873 [Silfverberg, Caldara]

p. 164, add LU to distribution of Tychius (Tychius) crassirostris Kirsch, 1871 [Caldara]

p. 164, correct year for Tychius (Tychius) curvirostris C.N.F. Brisout de Barneville to 1863b

p. 166, add LU to distribution of Tychius (Tychius) junceus (Reich, 1797) [Caldara]

p. 166, add under Tychius: [Caldara] kambulini Bajtenov, 1980b: 128 (Neotychius) A: KZ

p. 167, add LU to distribution of Tychius (Tychius) lineatulus Stephens, 1831 [Caldara]

p. 167, add IT to distribution of Tychius (Tychius) marismontis Casalini \& Colonnelli, 2004 [Caldara]

p. 167, add LU to distribution of Tychius (Tychius) medicaginis C.N.F. Brisout de Barneville, 1862 [Caldara]

p. 167, add LU to distribution of Tychius (Tychius) meliloti Stephens, 1831 [Caldara]

p. 168, add LA LU to distribution of Tychius (Tychius) parallelus (Panzer, 1794) [Silfverberg, Caldara]

p. 169, add LU to distribution of Tychius (Tychius) picirostris (Fabricius, 1787) [Caldara]

p. 169, add LA LT to distribution of Tychius (Tychius) pumilus C.N.F. Brisout de Barneville, 1863 [Silfverberg]

p. 169, correct quinquepunctatus quinquepunctatus (Linnaeus, 1758) with quinquepunctatus (Linnaeus, 1758) and add LU to distribution [Caldara]

p. 169, delete quinquepunctatus obscuripes Korotyaev, 1996 [Caldara]

p. 169, add obscuripes Korotyaev, 1996 to the synonyms of Tychius (Tychius) quinquepunctatus (Linnaeus, 1758) as correctly reported in New Acts p. 52 [Caldara]

p. 170, add LU to distribution of Tychius (Tychius) schneideri (Herbst, 1795) [Caldara]

p. 170, add LU to distribution of Tychius (Tychius) squamulatus Gyllenhal, 1835 [Caldara]

p. 170, add LU to distribution of Tychius (Tychius) stephensi Schoenherr, 1835 [Caldara]

p. 171, add LA LT to distribution of Tychius (Tychius) trivialis Boheman, 1843 [Silfverberg, Alonso-Zarazaga]

p. 172, add LT LU to distribution of Bagous alismatis (Marsham, 1802) [Silfverberg, Caldara]

p. 172, add in synonymy of Bagous alismatis (Marsham, 1802): productus Gravenhorst, 1807: 202 (Rhynchaenus)

p. 173, add EN to distribution of Bagous binodulus (Herbst, 1795) [Silfverberg]

p. 173, add LA to distribution of Bagous collignensis (Herbst, 1797) [Silfverberg]

p. 173, add NR to distribution of Bagous diglyptus Boheman, 1845 [Silfverberg]

p. 173, add LA LT NR to distribution of Bagous frit (Herbst, 1795) and correct page to 256 [Silfverberg, Alonso-Zarazaga]

p. 174, add LT LU NR to distribution of Bagous glabrirostris (Herbst, 1795) [Silfverberg, Caldara]

p. 174, add LU NR to distribution of Bagous limosus (Gyllenhal, 1827) [Silfverberg, Caldara]

p. 174, add LU NR to distribution of Bagous lutosus (Gyllenhal, 1827) [Silfverberg, Alonso-Zarazaga]

p. 174, add LU NR to distribution of Bagous lutulentus (Gyllenhal, 1813) [Silfverberg, Alonso-Zarazaga]

p. 174, add NR to distribution of Bagous lutulosus (Gyllenhal, 1813) [Silfverberg]

p. 175, add SB to distribution of Bagous puncticollis Boheman, 1845

p. 175, add SZ to distribution of Bagous rufimanus Péricart, 1989 [Caldara]

p. 176, add LT LU to distribution of Bagous subcarinatus Gyllenhal, 1836 [Silfverberg, Caldara]

p. 176, for Bagous tempestivus Herbst, 1795, add (Curculio) as original combination

p. 176, add LT LU to distribution of Bagous tempestivus (Herbst, 1795) [Silfverberg, Caldara]

p. 180, add under Ceutorhynchus: catenulatus Korotyaev, 2012: 83 A: SCH

p. 181, add CY to distribution of Ceutorhynchus erysimi (Fabricius, 1787)

p. 182, add CY to distribution of Ceutorhynchus hirtulus Germar, 1824

p. 182, add EN GB LT to distribution of Ceutorhynchus inaffectatus Gyllenhal, 1837

p. 182, indent veneris Dalla Torre, 1922, as a synonym of Ceutorhynchus inaffectatus Gyllenhal, 1837

p. 184, delete floralis Olivier from synonymy under Ceutorhynchus obstrictus (Marsham, $1802)$; it is already correctly placed in synonymy of Cleopomiarus plantarum (Germar, 1824) on p. 136

p. 184, add CY to distribution of Ceutorhynchus pallidactylus (Marsham, 1802)

p. 184, transfer Ceutorhynchus philippovi Korotyaev under synonymy of $C$. subcoeruleipennis Voss below

p. 184, add LT SB to distribution of Ceutorhynchus picitarsis Gyllenhal, 1837

p. 186, add in synonymy of Ceutorhynchus subcoeruleipennis Voss, 1958: philippovi Korotyaev, 1980: 230

p. 187, add LU to distribution of Ceutorhynchus thlaspi C.N.F. Brisout de Barneville, 1869

p. 187, delete floralis Fabricius in synonymy of Ceutorhynchus typhae (Herbst, 1795) (a later use 
of Curculio floralis Paykull, 1792, the latter is mentioned as the source)

p. 187, add parentheses around the original genus for palustris Edmonds, 1930 in synonymy of Ceutorhynchus typhae (Herbst, 1795)

p. 189, add CY to distribution of Coeliodes transversealbofasciatus (Goeze, 1777)

p. 190, add WS to distribution of Coeliodinus rubicundus (Herbst, 1795)

p. 190, delete MA from distribution of Datonychus melanostictus (Marsham, 1802)

p. 196, correct distribution of Mogulones pseudopollinarius Har. Lindberg, 1950 to CI

p. 197, correct page for albofasciatus Goeze, 1777 to 411 [in synonymy of Nedyus quadrimaculatus (Linnaeus, 1758)]

p. 197, add as synonyms of Nedyus quadrimaculatus (Linnaeus, 1758):

ovalis Linnaeus, 1760: 180 (Curculio) ovatus Linnaeus, 1758: 382 (Curculio) [HN]

p. 197, delete urticae O.F. Müller, 1776 (already in correct synonymy of Parethelcus pollinarius)

p. 198, add as a synonym of Oprohinus suturalis (Fabricius, 1775):

salicinus Schrank, 1781: 115 (Curculio)

p. 202, add SZ to distribution of Sirocalodes mixtus (Mulsant \& Rey, 1859)

p. 202, add MA to distribution of Stenocarus ruficornis (Stephens, 1831)

p. 204, add MA to distribution of Trichosirocalus centrimacula (Schultze, 1899)

p. 204, delete MA from distribution of Trichosirocalus troglodytes (Fabricius, 1787)

p. 205, replace the mention of Curculio guttula Fabricius, 1787 after Allodactylus Weise with: type species Curculio geranii Paykull, 1800

p. 207, Neoplatygaster is of feminine gender. Change ending of venustus to venusta

p. 209, add under Xenysmoderodes: concavus Yang, Zhang \& Ren, 2013: 534 A: GUX flos Yang, Zhang \& Ren, 2013: 537 A: GUI ZHE

p. 209, correct year for pseudacori Fabricius to $1792 \mathrm{~b}$ [in synonymy of Mononychus punctumalbum (Herbst, 1784)]

p. 209, delete rondoui Vuillet, 1911 from synonymy of Mononychus punctumalbum (Herbst, 1784) (correctly placed as valid species)

p. 209, delete the last WS in distribution of Eubrychius velutus (Beck, 1817)

p. 210, add under Pelenomus: curvatus Yang \& Huang, 2013: 413 A: YUN

p. 210, add HEI to distribution of Pelenomus canaliculatus (Fåhraeus, 1843)

p. 210, add BE to distribution of Pelenomus olssoni (Israelson, 1972)

p. 210, add SB FUJ GUI to distribution of Pelenomus quadricorniger (Colonnelli, 1986)

p. 210, delete SE and add FUJ GUI GUX HUN JIX LIA ZHE to distribution of Pelenomus roelofsi (Hustache, 1916) p. 210, add HEI HUB to distribution of Pelenomus waltoni (Boheman, 1843) and correct NAR to NARi

p. 211, add LU to distribution of Rhinoncus albicinctus Gyllenhal, 1837

p. 211, add SB to distribution of Rhinoncus bruchoides (Herbst, 1784)

p. 211, correct year for gramineus Fabricius to $1792 \mathrm{~b}$ [in synonymy of Rhinoncus inconspectus (Herbst, 1795)]

p. 212, correct NAR to NARi in distribution of Rhinoncus perpendicularis (Reich, 1797)

p. 213, add FUJ GUI GUX HUN JA JIX ZHE NARi to distribution of Rhinoncomimus (Homorosomulus) latipes Korotyaev, 1997

p. 213, add HUN JIX TAI to distribution of Rhinoncomimus (Homorosomulus) rhytidosomoides (H. Wagner, 1944)

p. 213, add to Rhinoncomimus subgenus Rhinoncomimus: continuus Huang, Yoshitake \& Zhang, 2013: 151 A: GUI GUX SCH

p. 213, add GUI HUB HUN JIX ZHE to distribution of Rhinoncomimus (Rhinoncomimus) klapperichi H. Wagner, 1940

p. 213, add GUA GUI HUN JIX to distribution of Rhinoncomimus (Rhinoncomimus) niger Chûjô \& Morimoto, 1959

p. 213, add HUN to distribution of Rhinoncomimus (Rhinoncomimus) robustus Voss, 1958

p. 213, add after the type species of genus Rutidosoma, of subgenus Rutidosoma and of synonym Oligodites, (= Rhinoncus graminosus Gistel, 1857)

p. 213, Rutidosoma is of neuter gender. Change ending of graminosus to graminosum

p. 213, delete graminosus Gistel, 1857 as a synonym, it is the valid name for the species

p. 213, add under Scleropterus Schoenherr, 1825: klausnitzeri Bajtenov, 1983: 18 A: ES

p. 213, add LT to distribution of Scleropteridius fallax Otto, 1897

p. 214, add LU to distribution of Coryssomerus capucinus (Beck, 1817)

p. 215, add under Lobotrachelus Schoenherr, 1838: albocollis Kumar \& Pajni, 1996: 113 A: SD albosparsus Kumar \& Pajni, 1996: 112 A: UP

p. 215, add ORR to distribution of Lobotrachelus laporteae Marshall, 1938

p. 217, add under Telephae Pascoe, 1870: marshalli Kumar \& Pajni, 1995: 19 A: HP

p. 218, add MA to distribution of Choerorhinus squalidus Fairmaire, 1858

p. 218, add LU to distribution of Cossonus (Caenocossonus) cylindricus (C.R. Sahlberg, 1835)

p. 218, delete foveicollis Faust, 1894c (not a Palaearctic species) [Maughan]

p. 218, add LU to distribution of Cossonus (Cossonus) linearis (Fabricius, 1775) 
p. 218, transfer the species parallelepipedus Herbst, 1795 and its synonyms to subgenus Caenocossonus Voss, 1955 [Maughan]

p. 219, add MA to distribution of Mesites (Mesites) cunipes (Boheman, 1838)

p. 219, add MA to distribution of Mesites (Mesites) pallidipennis (Boheman, 1838)

p. 220, correct year for Pseudocossonus planatus (Marshall) to 1938a [Maughan]

p. 221, correct type species of Tytthomimus Champion, 1909 to Tytthomimus rubicundus

p. 221, add SP to distribution of Caulophilus oryzae (Gyllenhal, 1838)

p. 221, indent pinguis Horn, 1873, in synonymy of Caulophilus oryzae (Gyllenhal, 1838)

p. 221, under genus Cotaster, add: [Maughan, Alonso-Zarazaga]

cuneipennis Aubé, 1850: 341 (Styphlus) E: AU BH CR CZ FR GE HU IT ME PL RO SB SK SL SZ

p. 221, delete uncipes carniolicus Folwaczny (infrasubspecific) [Caldara]

p. 221, replace uncipes uncipes with Cotaster uncipes (Boheman, 1838) and replace distribution with AN FR GE IT LU SP SZ [Caldara, Alonso-Zarazaga]

p. 222, delete synonym cuneipennis Aubé, 1850 for Cotaster (Cotaster) uncipes (Boheman, 1838) [Maughan, Caldara]

p. 223, add to Neumatora: annamariae Magrini, Abbazzi \& Petrioli, 2013: 362 E: IT(Lampedusa I.)

p. 223, correct ferrugineus Waltl, 1839 to ferrugineum Waltl, 1839b, and indent to make it a synonym of Hexarthrum exiguum (Boheman, 1838) [Maughan $\&$ Alonso-Zarazaga]

p. 224, correct page to 372 for Pselactus capitulatus (Wollaston, 1861) and (Rhyncolus) to (Phloeophagus)

p. 224, correct (Rhyncolus) after Pselactus piceus subparallelus Wollaston to (Phloeophagus)

p. 224, delete the two following lines after Pselactus proximus Wollaston: they are repeated

p. 224, under genus Pselactus, add:

simplicipes Wollaston, 1861c: 374 (Phloeophagus)

$\mathbf{N}$ : CI (Tenerife)

p. 224, add LU MA to distribution of Pselactus spadix spadix (Herbst, 1795)

p. 225, add LU to distribution of Stereocorynes truncorum (Germar, 1824)

p. 226, add NARi to distribution of Euophryum confine (Broun, 1881)

p. 227, add MA to distribution of Melicius gracilis (Rosenhauer, 1856)

p. 227, add LU to distribution of Phloephagus lignarius (Marsham, 1802)

p. 228, correct year for Rhyncolus (Rhyncolus) sculpturatus Waltl to $1839 \mathrm{~b}$ [Maughan]

p. 230, correct year for Rhadinomerus lenis Marshall and Rhadinomerus rugirostris Marshall to $1938 \mathrm{~b}$ p. 231, add LU to distribution of Cryptorhynchus lapathi (Linnaeus, 1758)

p. 232, correct year for Shirahoshizo corni (Marshall) to $1938 b$

p. 233, add LU to distribution of Acalles (Acalles) fallax Boheman, 1844

p. 234, add LU to distribution of Acalles (Acalles) misellus Boheman, 1844

p. 234, add LU to distribution of Acalles (Acalles) parvulus Boheman, 1837

p. 234, correct year for Acalles (Acalles) sierrae H. Brisout de Barneville to 1866

p. 235, add under Calacalles subgenus Nanoacalles: lepensis Stüben, 2013b: 2 N: CI(Gomera)

p. 236, add under Dichromacalles subgenus Balcanacalles:

lentisci Chevrolat, 1861a: 124 (Acalles) E: SP N: AG MO

raffrayi Desbrochers des Loges, 1871: 355 (Acalles)

p. 236, add under Dichromacalles subgenus Dichromacalles:

algecirasensis Stüben, 2013c: 111 E: SP

p. 236, add MA to distribution of Dichromacalles (Dichromacalles) diocletianus (Germar, 1817)

p. 236, transfer Dichromacalles (Dichromacalles) lentisci (Chevrolat, 1861) and its synonym to Dichromacalles subgenus Balcanacalles

p. 242, add IT SL to distribution of Gasterocercus depressirostris depressirostris [Caldara, Alonso-Zarazaga]

p. 244, correct year and page for Torneuma (Torneuma) robustum Dieck to 1869: 7

p. 244, correct year and page for tingitanum Dieck to 1869: 8 [in synonymy of Torneuma (Torneuma) robustum (Dieck)]

p. 246, add under Borborocoetes Schoenherr: kandaharensis Voss, 1959b: 110 A: AF

p. 247, delete $\mathrm{CH}$ and add BEI to distribution of Gronops (Asperogronops) inaequalis Boheman, 1842

p. 247, add under Gronops subgenus Gronopidius: fasciatus Küster, 1851: 60 E: SP N: CI EG MO A: CY

p. 247, transfer fasciatus Küster under Gronops subgenus Gronops to subgenus Gronopidius

p. 251, add LU to distribution of Gronops (Gronops) lunatus (Fabricius, 1775)

p. 251, place CI before MO in distribution of Listroderes costirostris (Schoenherr, 1826)

p. 252, add as a synonym of Lepidophorus Kirby, 1837: Vitavitus Kissinger, 1974: 193 type species Vitavitus thulius Kissinger, 1974

p. 252, add under Lepidophorus Kirby, 1837:

thulius Kissinger, 1974: 194 (Vitavitus) A: FE NAR

p. 253, add MA to distribution of Rhytideres (Rhytideres) plicatus (Olivier, 1790)

p. 253, add under Seidlitzia: 
escalerai Pelletier \& Borovec, 2013: 280 N: MO

p. 253, delete the word barynotoides in front of Seidlitzia barynotoides Escalera, 1914 and Seidlitzia latesparsa Antoine, 1953

p. 256, correct albida to albidus in the synonymy of the type species of genus Alatavia Bajtenov, 1974

p. 256, delete chinensis Boheman, 1840 as valid species, and place as a synonym of Brachyderes incanus (Linnaeus, 1758); the locality $\mathrm{CH}$ is erroneous

p. 256, add LU to distribution of Brachyderes (Brachyderes) incanus (Linnaeus, 1758)

p. 257, transfer testipes Schrank, 1798 to synonymy of Otiorhynchus (Pendragon) ovatus ovatus (Linnaeus, 1758); it is a replacement name for Curculio rufipes Scopoli, 1763

p. 257, transfer murinus Boheman, 1840 to Pholicodes subgenus Pholicodes

p. 258, add to Pholicodes subgenus Pholicodes: [Pelletier] creticus Faust, 1889a: 74 (Strophomorphus) E: GR (Kríti)

p. 259, correct year for Pholicodes (Pholicodes) lepidopterus Boheman to $1839 \mathrm{~b}$ [Pelletier]

p. 259, add to Pholicodes subgenus Pholicodes: murinus Boheman, 1840a: 934 (Brachyderes) A: SA

p. 259, correct year for Pholicodes (Pholicodes) semicalvus Reitter to 1881 [Pelletier]

p. 260, correct year for Strophomorphus cretaceus aegyptiacus Pelletier to 1999b [Pelletier]

p. 260, delete Strophomorphus creticus Faust, 1889a [Pelletier]

p. 260, add CY to distribution of Strophomorphus impressicollis Tournier, 1874

p. 261, delete the insertion [=1871: 386] after Strophosoma (Neliocarus) ebenista Seidlitz, 1870: Seidlitz (1871: 381, note 2) stated that the original descriptions are those of 1870

p. 261, add LU to distribution of Strophosoma (Neliocarus) faber (Herbst, 1784)

p. 261, delete pilosum Fabricius in synonymy of Strophosoma (Neliocarus) faber (Herbst, 1784); correctly placed in synonymy of Cycloderes pilosulus (Herbst, 1795)

p. 261, delete the insertion [=1871: 386] after ovulum Seidlitz in synonymy of Strophosoma (Neliocarus) flavipes (Chevrolat, 1869): Seidlitz (1871: 381, note 2) stated that the original descriptions are those of 1870

p. 261, delete the insertion [=1871: 386] after Strophosoma (Neliocarus) formosum Seidlitz, 1870: Seidlitz (1871: 381, note 2) stated that the original descriptions are those of 1870

p. 261, add [HN] to ellipticum Hustache, 1941b in synonymy of Strophosoma (Neliocarus) jeani Pelletier, 2009 [Pelletier]

p. 261, add LU to distribution of Strophosoma (Neliocarus) nebulosum (Stephens, 1831) p. 261, add [HN] to retusum Marsham, 1802 in synonymy of Strophosoma (Neliocarus) nebulosum (Stephens, 1831)

p. 262, add LU to distribution of Strophosoma (Neliocarus) sus (Stephens, 1831)

p. 262, add [HN] to laterale Paykull in synonymy of Strophosoma (Neliocarus) sus (Stephens, 1831)

p. 262, add [RN, HN] to limbatum Fabricius in synonymy of Strophosoma (Neliocarus) sus (Stephens, 1831)

p. 262, correct valdejeroi to valderejoi

p. 262, add to subgenus Neliocarus C.G. Thomson, 1859:

zarazagai Ugarte San Vicente \& Salgueira Cerezo, 2009: 73 E: SP

p. 262, transfer Strophosoma (Strophosoma) canariense (Franz, 1995) to genus Moreiba in Laparocerini

p. 262, add FR LU to distribution of Strophosoma (Strophosoma) capitatum (DeGeer, 1775) [Pelletier, Alonso-Zarazaga]

p. 262, correct page for Strophosoma (Strophosoma) denudatum (Hustache, 1941) to 166 [Pelletier]

p. 262, correct year for ifranense Hoffmann to $1953 \mathrm{~b}$ [in synonymy of Strophosoma (Strophosoma) denudatum (Hustache, 1941)] [Pelletier]

p. 262, delete the insertion [=1871: 385] after Strophosoma (Strophosoma) globulus Seidlitz, 1870: Seidlitz (1871: 381, note 2) stated that the original descriptions are those of 1870

p. 263, add AL LU to distribution of Strophosoma (Strophosoma) melanogrammum melanogrammum (Forster, 1771)

p. 263, after subgenus Subcaulostrophus, correct the year of the type species to 1870

p. 263, delete the insertion [=1871: 45] after Strophosoma (Subcaulostrophus) sagitta Seidlitz, 1870: Seidlitz (1871: 381, note 2) stated that the original descriptions are those of 1870

p. 264, add original genus Cneorhinus after Attactagenus gracilicornis Hustache and its synonym transversicollis Hustache

p. 268, replace jucundus jucundus Voss, with just jucundus Voss

p. 268, delete jucundus similaris Voss, 1959b (originally a variety in an article where subspecies were used, so it was an infrasubspecific name)

p. 268, add NARi to distribution of Calomycterus setarius Roelofs, 1873

p. 270, add under Cyphicerus subgenus Cyphicerus: loochoensis Voss, 1971b: 51 A: JA

p. 272, add under Myllocerinus subgenus Myllocerinus: gussakovskii Nasreddinov, 1978d: 57 A: TD

p. 275, add:

genus Scaeorrhinus G.A.K. Marshall, 1944c: 439 type species Scaeorrhinus boops Marshall, 1944 kashmirensis Formánek, 1925: 19 (Otiorhynchus) A: KA

p. 278, correct TAIF to TAI in distribution of Myllocerus (Myllocerus) guttulus Matsumura, 1910 
p. 281, correct, under genus Sphaeroptochus Egorov \& Zherikhin, 1991, fascilatus to fasciolatus

p. 282, correct the type species of Rhypochromus Motschulsky, 1858 to Rhypochromus cruciger

p. 282, transfer Dermatoxenus binodosus Marshall in synonymy under Dermatoxenus scutellatus below

p. 283, add under Dermatoxenus:

scutellatus Heller, 1915b: 212 (Dermatodes) A: GUA ORR

binodosus Marshall, 1916b: 51

p. 284, add entry immediately below genus Barynotus: subgenus Barynotus Germar, 1817b: 341 type species Curculio obscurus Fabricius, 1775

p. 284, correct mainardii F. Solari to mainardii mainardii, and add a valid subspecies: [Caldara \& Alonso-Zarazaga]

mainardii alpicola Pesarini \& Pedroni, 2011: 162 E: IT

p. 284, add to Barynotus subgenus Barynotus: [Caldara \& Alonso-Zarazaga] monguzzii Pesarini \&Pedroni, 2011: 158 E: IT

p. 286, correct spelling of boghariensis (Desbrochers des Loges, 1892) [in synonymy with Cyclobarus moraguesi (Desbrochers des Loges, 1892) to bogahriensis [Pelletier]

p. 287, correct spelling of alternaevittatus (Desbrochers des Loges, 1905) [in synonymy with Cyrtolepus seidlitzi (Tournier, 1875) to alternevittatus [Pelletier] p. 287, add:

genus Holcophloeus Borovec \& Meregalli, 2013: 250 type species Trachyphloeus cruciatus Seidlitz, 1868

cruciatus Seidlitz, 1868: 103 (Trachyphloeus)

$\mathbf{N}: \mathrm{AG}$

laurae Borovec \& Meregalli, 2013: 255 N: MO weilli Borovec \& Meregalli, 2013: 256 N: LB

p. 287, place genus Massimiellus Borovec, 2009 after genus Holcorhinus Schoenherr, 1826

p. 288 , add a closing parenthesis to Holcorhinus siculus Seidlitz, 1868 after Sicilia

p. 289, add entry immediately before subgenus Fernandezius:

subgenus Faycanius Machado, 2012: 29 type species Otiorhynchus squamosus Brullé, 1839 [Machado]

p. 289, add to Laparocerus subgenus Faycanius (either from species incertae sedis on p. 290-292 or new): [Machado]

alluaudi alluaudi Uyttenboogaart, 1940: 55 N: CI (Gran Canaria)

alluaudi aytamis Machado, 2012: 33 N: CI (Gran Canaria)

anniversarius Machado, 2012: 37 N: CI (Gran Canaria)

arcanus Machado, 2012: 32 N: CI (Gran Canaria) dissidens Machado, 2012: 35 N: CI (Gran Canaria) squamosus squamosus Brullé, 1839: 71 (Otiorhynchus) N: CI (Gran Canaria) seniculus Wollaston, 1864: 353

squamosus tasarticus Machado, 2012: 21 N: CI (Gran Canaria)

p. 289, add to Laparocerus subgenus Guanchotrox: [Machado]

marmoratus Machado, 2012: 22 N: CI (Gran Canaria)

tirmensis Machado, 2012: 21 N: CI (Gran Canaria)

p. 290, add to Laparocerus subgenus Pecoudius: [Machado]

franzi Machado, 2012: 10 N: CI (Gran Canaria)

teldensis Machado, 2012: 11 N: CI (Gran Canaria)

p. 290, add under Laparocerus, species incertae sedis: affinis Wollaston, 1864: 358 N: CI [Machado]

p. 290, delete alluaudi Uyttenboogaart, 1940a (transferred to subgenus Faycanius) [Machado]

p. 290, add under Laparocerus, species incertae sedis:

[Machado]

bentejui bentejui Machado, 2012: 7 N: CI (Gran Canaria)

bentejui delicatulus Machado, 2012: 8 N: CI (Gran Canaria)

bentejui robustus Machado, 2012: 10 N: CI (Gran Canaria)

p. 291, add under Laparocerus, species incertae sedis: [Machado]

estevezi Machado, 2012: 13 N: CI (Gran Canaria) fraudulentus Machado, 2012: 14 N: CI (Gran Canaria)

p. 292, add under Laparocerus, species incertae sedis: [Machado]

ornatus Machado, 2012: 20 N: CI (Gran Canaria) osorio Machado, 2012: 25 N: CI (Gran Canaria)

rugosivertex Machado, 2012: 18 N: CI (Gran Canaria)

semipilosus Machado, 2012: 23 N: CI (Gran Canaria)

p. 292, delete squamosus Brullé, 1839 and its synonym seniculus Wollaston, 1864 (transferred to subgenus Faycanius) [Machado]

p. 292, add under Laparocerus, species incertae sedis: [Machado]

tirajana Machado, 2012: 28 N: CI (Gran Canaria)

p. 292, delete vestitus affinis Wollaston, 1864 [Machado]

p. 292, correct vestitus vestitus Wollaston, 1864 to vestitus [Machado]

p. 292, add under Laparocerini:

genus Moreiba Alonso-Zarazaga, 2013b: 46 type species Strophosomus canariensis Franz, 1995 canariensis Franz, 1995: 37 (Strophosomus) N: CI

p. 300, under Rhinomias forticornis (Boheman, 1842), at least two synonyms have priority: Omias alpinus Gredler, 1841 and Curculio gracilipes Panzer, 1798; the precedence of Omias rugicollis Boheman, 1842 is not clear as well; any interested author should make the appropriate declarations of nomina oblita and nomen protectum under Art. 23.9.2 of the Code. 
p. 318, add under Otiorhynchus subgenus Lixorrhynchus: monoecirupis Lemaire, Ponel \& Alziar, 2012: 284 E: FR (Monaco)

p. 319, add in synonymy of Otiorhynchus (Magnanotius) obtusus Boheman, 1842: uhligii Łomnicki, 1894: 85

p. 323, correct year for type species of subgenus Nehrodistus to 1790

p. 323, add MAi to distribution of Otiorhynchus (Nehrodistus) armatus armatus Boheman, 1842

p. 323, correct year for Otiorhynchus (Nehrodistus) corruptor corruptor (Host) to 1790

p. 325, transfer Otiorhynchus (Nubidanus) breviusculus Stierlin, 1875 under synonymy of $O$. (Nubidanus) poricollis Schoenherr, 1832, and O.(N.) arnoldianus Nasreddinov, 1976, O. (N.) balchaschensis Bajtenov, 1974, O. (N.) christophi Stierlin, 1876, $O$. (N.) conicirostris Stierlin, 1886, O. (N.) morosus Faust, 1889 and O. (N.) schmorli Stierlin, 1876 to Otiorhynchus subgenus Pseudotiorhynchus Magnano, 2004

p. 327, add LT NR PL to distribution of Otiorhynchus (Otiorhynchus) armadillo (Rossi, 1792)

p. 328, correct year for Otiorhynchus (Otiorhynchus) cardiniger (Host) to 1790

p. 330, add [HN] to Curculio haematopus Schrank, 1798 in synonymy of Otiorhynchus (Otiorhynchus) tenebricosus (Herbst, 1784)

p. 331, delete manfredi Magnano, 2001 and its synonym

p. 331, add after the type species of subgenus Paracryphiphorus Magnano (= Curculio catenulatus Panzer, 1795)

p. 331, reverse the synonymy of Curculio orbicularis Herbst, 1795 and C. catenulatus Panzer, 1795, Panzer's 1795b work has precedence over Herbst, 1795 a work, so the valid name of the species is Otiorhynchus catenulatus (Panzer, 1795); reversal of the precedence cannot be applied, since I have been unable to fulfill the requirements of Art. 23.9.1.2 for Curculio orbicularis Herbst, 1795

p. 332, add in synonymy of Otiorhynchus (Pendragon) ovatus ovatus (Linnaeus, 1758):

testipes Schrank, 1798: 495 (Curculio) [RN]

p. 332, indent pristodon K. Daniel as a synonym of Otiorhynchus (Pendragon) schusteri Stierlin, 1897

p. 339, add IT to distribution of Otiorhynchus stussineri [Caldara]

p. 340, add SZ to distribution of Otiorhynchus (Pseudocryphiphorus) chrysostictus Gyllenhal, 1834

p. 340, add before subgenus Rimenostolus (from genus, Davidian \& Korotyaev, 2012):

subgenus Pseudotiorhynchus Magnano, 2004b: 28 type species Arammichnus ruminalis Faust, 1894

arnoldianus Nasreddinov, 1976: 106 A: TD

atamuradovi Davidian \& Korotyaev, 2012: 365

A: TM

balchaschensis Bajtenov, 1974d: 174 A: KZ christophi Stierlin, 1876: 510 A: KZ TM

conicirostris Stierlin, 1886b: 227 E: ST A: IN KZ TM

jelineki Magnano, 2004b: 29 (Pseudotiorhynchus)

A: IN

kurshedi Davidian \& Korotyaev, 2012: 364 A:

KZ UZ

morosus Faust, 1889c: 129 A: KZ TM TR UZ

olegi Davidian \& Korotyaev, 2012: 366 A: TM

podlussanyi Magnano, 2004b: 30

(Pseudotiorhynchus) A: TM

ruminalis Faust, 1894a: 53 (Arammichnus) A: KZ TM

saraevi Davidian \& Korotyaev, 2012: 367 A: KZ

schmorli Stierlin, 1876: 507 A: KZ TM

p. 340, add GE to distribution of Otiorhynchus (Rosvalestus) globus Boheman, 1842 and add as synonyms the following taxa:

kahleni Magnano, 1991: 115 [HN]

manfredi Magnano, 2001c: 71 [RN]

p. 345, add under Otiorhynchus, species incertae sedis: mucronatus Paykull, 1792: 81 (Curculio) [HN] E: GE

p. 346, delete the genus Pseudotiorhynchus Magnano, 2004 and its species, and transfer to p. 340 as a subgenus of Otiorhynchus Germar, 1822 (overlooked placement by Davidian \& Korotyaev, 2012)

p. 348, add (Sardegna) to distribution of Dolichomeira arburensis Pierotti \& Bellò, 2000 [Pierotti]

p. 348, add (Sardegna) to distribution of Dolichomeira caralitana Pierotti \& Bellò, 2000 [Pierotti]

p. 348, add (Sardegna) to distribution of Dolichomeira caroli Pierotti \& Bellò, 2000 [Pierotti]

p. 348, add (Sardegna) to distribution of Dolichomeira circumcincta Pierotti \& Bellò, 2000 [Pierotti]

p. 348, add (Sicilia) to distribution of Dolichomeira dubia Pierotti \& Bellò, 1994 [Pierotti]

p. 348, add (Sardegna) to distribution of Dolichomeira franscisci Pierotti \& Bellò, 2000 [Pierotti]

p. 348, add (Sardegna) to distribution of Dolichomeira ichnusae Pierotti \& Bellò, 2000 [Pierotti]

p. 348, add (Sardegna) to distribution of Dolichomeira jana Pierotti \& Bellò, 2000 [Pierotti]

p. 348, add (Sardegna) to distribution of Dolichomeira lentisci Pierotti \& Bellò, 2000 [Pierotti]

p. 348, add (Sardegna) to distribution of Dolichomeira marci Pierotti \& Bellò, 2000 [Pierotti]

p. 348, add (Sardegna) to distribution of Dolichomeira marcosellai Pierotti \& Bellò, 2000 [Pierotti]

p. 348, add (Sardegna) to distribution of Dolichomeira melonii Pierotti \& Bellò, 2000 [Pierotti]

p. 348, add (Sardegna) to distribution of Dolichomeira michaelis Pierotti \& Bellò, 2000 [Pierotti]

p. 348, add (Sicilia) to distribution of Dolichomeira microphthalma (Seidlitz, 1868) [Pierotti]

p. 348, add (Sardegna) to distribution of Dolichomeira nasuta (Péricart, 1963) [Pierotti]

p. 348, add (Sardegna) to distribution of Dolichomeira nugorensis Pierotti \& Bellò, 2000 [Pierotti] 
p. 348, add (Sardegna) to distribution of Dolichomeira nuragica Pierotti \& Bellò, 2000 [Pierotti]

p. 348, add (St. Pietro Is.) to distribution of Dolichomeira occidentalis Pierotti \& Bellò, 2000 [Pierotti]

p. 348, add (Sardegna) to distribution of Dolichomeira olearia Pierotti \& Bellò, 2000 [Pierotti]

p. 348, add (Sardegna) to distribution of Dolichomeira oppidana Pierotti \& Bellò, 2000[Pierotti]

p. 348, add under Dolichomeira F. Solari: [Pierotti] parvula Pierotti, 2013b: 6 E: IT (Sardegna)

p. 348, add (Sardegna) to distribution of Dolichomeira philippi Pierotti \& Bellò, 2000 [Pierotti]

p. 348, add (Sardegna) to distribution of Dolichomeira plumbariae Pierotti \& Bellò, 2000 [Pierotti]

p. 348, add (Sardegna) to distribution of Dolichomeira sassariensis (Desbrochers, 1888) [Pierotti]

p. 348, add (Sardegna) to distribution of Dolichomeira scodinai Pierotti \& Bellò, 2000 [Pierotti]

p. 348, add (Sardegna) to distribution of Dolichomeira seidlitzi (Desbrochers, 1888) [Pierotti]

p .348, add (Sardegna) to distribution of Dolichomeira sulcitana Pierotti \& Bellò, 2000[Pierotti]

p. 348, add (Sardegna) to distribution of Dolichomeira tubaedicata Pierotti \& Bellò, 2000[Pierotti]

p. 348, add (Sardegna) to distribution of Dolichomeira vagnonii Pierotti \& Bellò, 2000 [Pierotti]

p. 349, correct page for Euplister susanae (Seidlitz) to 26

p. 349, correct page for Gymnomorphus mononychus (Seidlitz) to 75

p. 349, add (Sardegna) to distribution of Heteromeira brachyrhina Pierotti, 2011 [Pierotti]

p. 349, add (Corse) to FR and (Capraia Is.) to IT in distribution of Heteromeira caprasiae (A. \& F. Solari, 1933) [Pierotti]

p. 349, add (Sardegna) to distribution of Heteromeira damryi (Tournier, 1876) [Pierotti]

p. 349, add (Corse) to FR and (Sardegna) to IT in distribution of Heteromeira latiscrobs (Desbrochers, 1871) [Pierotti]

p. 349, add (Sicilia) to distribution of Heteromeira pacei Bellò \& Pierotti, 1992) [Pierotti]

p. 349, add (Sardegna) to distribution of Heteromeira poggii Pierotti, 2011 [Pierotti]

p. 349, add (Sardegna) to distribution of Heteromeira proxima F. Solari, 1955 [Pierotti]

p. 349, add (Sicilia) to distribution of Heteromeira sicula (Desbrochers, 1892) [Pierotti]

p. 349, add (Sardegna) to distribution of Leptomeira meregallii Pierotti \& Bellò, 1997 [Pierotti]

p. 349, add (Corse) to distribution of Leptomeira nupta Pierotti \& Bellò, 2001 [Pierotti]

p. 349, add (Corse) to distribution of Leptomeira squamulata (Reiche, 1862) [Pierotti]

p. 350, delete sedilloti C.N.F. Brisout de Barneville, 1882 from synonymy under Meira crassicornis Jacquelin du Val, 1853 [Alonso-Zarazaga, Pierotti] p. 350, correct crassicornis Jacquelin du Val, 1853 to crassicornis crassicornis [Alonso-Zarazaga, Pierotti]

p. 350, add under Meira Jacquelin du Val, 1853: [Pierotti]

crassicornis coironensis Delaunay \& Melle, 2013:

3 E: FR

diottii Pierotti, 2013c: 595 E: IT

etrusca Pierotti, 2012a: 1 E: IT

lavagnei lata Delaunay \& Melle, 2013: 12 E: FR

lavagnei komezai Delaunay \& Melle, 2013: 14 E: FR

p. 350, add (Meda Mayor I.) to distribution of Meira medae Pierotti, Bellò \& Alonso-Zarazaga, 2010 [Pierotti]

p. 351, add under Meira Jacquelin du Val, 1853: [Pierotti] oenotria Pierotti, 2013a: 1 E: IT

rolandi Delaunay \& Melle, 2013: 8 E: FR

ronani Delaunay \& Melle, 2013: 10 E: FR

sabina Pierotti, 2012a: 4 E: IT

sedilloti sedilloti C.N.F. Brisout de Barneville, 1882: clxxix E: FR

sedilloti chobauti Delaunay \& Melle, 2013: 6 E: FR

umbra Pierotti, 2013a: 4 E: IT

p. 351, add LU to distribution of Peritelus sphaeroides Germar, 1824

p. 351, add [RN] to Neoperitelinus O'Brien \& Wibmer, 1982

p. 351, add [HN] to Peritelinus F. Solari, 1955

p. 351, add (Is. Eolie) to distribution of Pseudomeira aeolica Bellò, Pesarini \& Pierotti, 1997 [Pierotti]

p. 351, add (Sardegna) to distribution of Pseudomeira anachoreta Meloni, Pierotti \& Bellò, 2001 [Pierotti]

p. 351, delete the words "sensu F. Solari, 1955" after the type species of Peritelinus F. Solari, 1955 in synonymy of Pseudomeira Stierlin, 1881 [AlonsoZarazaga, Pierotti]

p. 351, add under Pseudomeira Stierlin: [Pierotti] barbaricina Pierotti, 2013b: 2 E: IT (Sardegna)

p. 351, add (I. Gorgona) to distribution of Pseudomeira bartolii Bellò, Pesarini \& Pierotti, 1997 [Pierotti]

p. 352, add under Pseudomeira Stierlin: [Pierotti] confusa Pierotti, 2012b: 3 E: IT(Sicilia) melonii Pierotti, 2013b: 4 E: IT(Sardegna)

p. 352, add (I. Pantelleria) to distribution of Pseudomeira cossyrica Pierotti \& Bellò, 1994 [Pierotti]

p. 352, correct page for Pseudomeira echidna (Seidlitz) to 56

p. 352, add (Sardegna) to distribution of Pseudomeira eleonorae Pierotti \& Bellò, 1996 [Pierotti]

p. 352, add (Is. Baleares) to distribution of Pseudomeira eremita Pierotti , Bellò \& Alonso-Zarazaga, 2010 [Pierotti]

p. 352, add (Sicilia) to distribution of Pseudomeira exigua (Stierlin, 1861) [Pierotti]

p. 352, add (Sardegna) to distribution of Pseudomeira fancelloi Meloni, Pierotti \& Bellò, 2001 [Pierotti] 
p. 352, add (Corse) to distribution of Pseudomeira ferdinandi (Sainte-Claire Deville, 1914) [Pierotti]

p. 352, add (Corse) to distribution of Pseudomeira foveithorax (Desbrochers, 1875) [Pierotti]

p. 352, correct page for Pseudomeira gougeletii (Seidlitz) to 62

p. 352, correct page for Pseudomeira grenierii (Seidlitz) to 60

p. 352, add (I. Elba) to distribution of Pseudomeira holdhausi (A. \& F. Solari, 1907) [Pierotti]

p. 352, place the species Pseudomeira kapleri Pierotti \& Bellò, 1996 and P. kiesenwetteri Seidlitz, 1865 below P. inviridis (Pic, 1908)

p. 352, add (Sardegna) to distribution of Pseudomeira incognita Osella \& Gregori, 1989 [Pierotti]

p. 352, add (Sardegna) to distribution of Pseudomeira inopinata Pierotti \& Bellò, 1996 [Pierotti]

p. 352, add (Corse) to distribution of Pseudomeira insularis (Desbrochers, 1871) [Pierotti]

p. 352, add (Is. Baleares) to distribution of Pseudomeira inviridis (Pic, 1908) [Pierotti]

p. 352, correct page for Pseudomeira kiesenwetterii (Seidlitz) to 50

p. 352, add (Sardegna) to distribution of Pseudomeira leoi Pierotti \& Bellò, 1996 [Pierotti]

p. 352, add (Corse) to FR and (Sardegna) to IT in distribution of Pseudomeira lostiae (Desbrochers, 1892) [Pierotti]

p. 352, add (Sardegna) to distribution of Pseudomeira macrocephala Meloni, Pierotti \& Bellò, 2001 [Pierotti]

p. 352, add (Sardegna) to distribution of Pseudomeira montisalbi Pierotti \& Bellò, 1996 [Pierotti]

p. 352, add (Corse) to distribution of Pseudomeira muscorum (Desbrochers, 1871) [Pierotti]

p. 352, add (Sicilia) to distribution of Pseudomeira nebrodensis Pierotti, 2009 [Pierotti]

p. 352, add (Sicilia) to distribution of Pseudomeira osellai Pierotti \& Bellò, 1994 [Pierotti]

p.352, correct page for Pseudomeira parvula (Seidlitz) to 55

p. 352, add (Sicilia) to distribution of Pseudomeira pfisteri (Stierlin, 1864) [Pierotti]

p. 353, add (Sicilia) to distribution of Pseudomeira reitteri (Vitale, 1903) [Pierotti]

p. 353, correct spelling for brucki Seidlitz to bruckii and page to 53 [in synonymy of Pseudomeira rudis (Boheman, 1842)]

p. 353, add (Sardegna) to distribution of Pseudomeira sardoa (Costa, 1884) [Pierotti]

p. 353, add (I. Asinara) to distribution of Pseudomeira sinuariae Osella \& Gregori, 1989 [Pierotti]

p. 353, add (Sicilia) to distribution of Pseudomeira solarii (Péricart, 1963) [Pierotti]

p. 353, add (Corse) to distribution of Pseudomeira soror Pierotti \& Bellò, 2001 [Pierotti]

p. 353, add (Is. Baleares) to distribution of Pseudomeira tenuicornis (Schaufuss, 1882) [Pierotti] p. 353, add (Sardegna) to distribution of Pseudomeira transversicollis $\mathrm{F}$. Solari, 1955 [Pierotti]

p. 353, add (Corse) to distribution of Pseudomeira virgo Pierotti \& Bellò, 2001 [Pierotti]

p. 353, add (Sicilia) to distribution of Pseudomeira vitalei (Desbrochers, 1892) [Pierotti]

p. 353, correct page for Pseudomeira sicula (Seidlitz) to 46

p. 353, add (I. Columbrete Mayor) to distribution of Pseudoperitelus espanoli (Roudier, 1958) [Pierotti]

p. 353, add (Mallorca) to distribution of Pseudoperitelus lopezi (Hoffmann, 1961) [Pierotti]

p. 353, add (Sardegna) to distribution of Pseudosimo juniperi (Desbrochers, 1888) [Pierotti]

p. 353, transfer genus Simo Dejean, 1821 and its species below genus Simmeiropsis Pierotti \& Bellò on p. 354

p. 353, add (Sicilia) to distribution of Simo grandis (Desbrochers, 1888) [Pierotti]

p. 353, add LU to distribution of Simo hirticornis (Herbst, 1795)

p. 354, transfer major Desbrochers des Loges under synonymy of Simo variegatus (Boheman, 1842) below [Pierotti]

p. 354, add LU to distribution of Simo variegatus (Boheman, 1842) and add as a synonym: major Desbrochers des Loges, 1896b: 34 (Peritelus) The distribution $\mathrm{KZ}$ for the latter is probably wrong.

p. 354, add under Simmeiropsis Pierotti \& Bellò, 2013: [Pierotti]

algharbensis Pierotti, Germann \& Braunert, 2013: 274 E: PT

lusitana Pierotti, Germann \& Braunert, 2013: 278 E: PT

p. 354, add (Sardegna) to distribution of Simmeiropsis anachoreta Pierotti \& Bellò, 2006 [Pierotti]

p. 354, add (Sardegna) to distribution of Simmeiropsis astragali (Stierlin, 1861) [Pierotti]

p. 354, add (Sardegna) to distribution of Simmeiropsis germanni Pierotti \& Bellò, 2006 [Pierotti]

p. 354, add (Sardegna) to distribution of Simmeiropsis ignorata (A. \& F. Solari, 1922) [Pierotti]

p. 354, add (Sardegna) to distribution of Simmeiropsis montana (A. \& F. Solari, 1922) [Pierotti]

p. 354, add (Sardegna) to distribution of Simmeiropsis melonii Pierotti \& Bellò, 2006 [Pierotti]

p. 354, add (Sardegna) to distribution of Simmeiropsis mulasi Pierotti \& Bellò, 2006 [Pierotti]

p. 354, add (Sardegna) to distribution of Simmeiropsis osellai Pierotti \& Bellò, 2006 [Pierotti]

p. 354, add (Sardegna) to distribution of Simmeiropsis ottonis (Reitter, 1913) [Pierotti]

p. 354, correct page for Simmeiropsis planidorsis (Seidlitz) to 69

p. 354, correct page for Simmeiropsis platysoma (Seidlitz) to 57

p. 354, add (Sardegna) to distribution of Simmeiropsis supramontana Pierotti \& Bellò, 2006 [Pierotti] 
p. 354, add (Sardegna) to distribution of Simmeiropsis tenuisetis Pierotti \& Bellò, 2006 [Pierotti]

p. 354, add (Sardegna) to distribution of Simmeiropsis teucrii Pierotti \& Bellò, 2006 [Pierotti]

p. 354, add (Sardegna) to distribution of Simmeiropsis vatia Pierotti \& Bellò, 2006 [Pierotti]

p. 354, add (Sardegna) to distribution of Simmeiropsis virginum Pierotti \& Bellò, 2006 [Pierotti]

p. 356, add under Dichorrhinus: alziari Germann, 2013: 6 A: CY geiseri Germann, 2013: 3 E: GR(Samos I.) A: TR

p. 356, add under Parascythopus: intrusus Kôno, 1948a: 169 (Phyllobius) Ei: GE NL NR A: JA SC NARi

exsulans Heijermann \& Magnano, 2000: 198 saltinii Colonnelli, 2013: 175 A: SY

p. 359, add the word "unjustified" to RN for carniolicus Gmelin, 1790 in synonymy of Phyllobius (Metaphyllobius) glaucus (Scopoli, 1763)

p. 359, add PL to distribution of Phyllobius (Metaphyllobius) jacobsoni Smirnov, 1913

p. 359, add in synonymy of Phyllobius (Metaphyllobius) pomaceus Gyllenhal, 1834: prasinus Olivier, 1791: 559 (Curculio)

p. 360, place in synonymy of Phyllobius (Nemoicus) oblongus (Linnaeus, 1758):

mali Fabricius, 1782: 499 (Curculio) [with year corrected]

p. 361, transfer Phyllobius (Phyllobius) intrusus Kôno, 1948 to genus Parascythopus

p. 362, delete mali Fabricius from synonymy of Phyllobius pyri (Linnaeus, 1758)

p. 364, add IT to distribution of Auchmeresthes kiesenwetteri Kraatz, 1862 [Caldara]

p. 365, add IT to distribution of Liophloeus (Liophloeodes) lentus Germar, 1824 [Caldara]

p. 365, add IT to distribution of Liophloeus (Liophloeus) tessulatus (O.F. Müller, 1776) [Caldara]

p. 369, add NARi to distribution of Polydrusus (Eudipnus) formosus (Mayer, 1779)

p. 369, add in synonymy of Polydrusus (Eudipnus) mollis (Strøm, 1768):

chrysopterus Schrank, 1781: 125 (Curculio)

p. 370, add NARi to distribution of Polydrusus (Eurodrusus) cervinus (Linnaeus, 1758)

p. 370, delete undulatus Gmelin from synonymy of Polydrusus (Eurodrusus) cervinus (Linnaeus, 1758)

p. 370, delete prasinus Olivier from synonymy of Polydrusus (Eurodrusus) planifrons planifrons Gyllenhal, 1834

p. 371, add [NP] to Polydrusus (Eustolus) flavipes flavipes (DeGeer, 1775); it is a homonym of Curculio flavipes Fabricius, 1775 and has been declared nomen protectum in Alonso-Zarazaga (2014, pp. 64-65)

p. 373, add RO to distribution of Polydrusus (Polydrusus) ferrugineus Boheman, 1840

p. 374, add under Polydrusus subgenus Polydrusus: kadleci Borovec \& Germann, 2013: 76 A: IN TR wymanni Borovec \& Germann, 2013: 78 E: GR(Samos I.)

p. 374, add to synonymy of Polydrusus (Polydrusus) korbi Stierlin, 1888:

korbianus Yunakov, 2013: 64 [unjustified RN]

p. 374, add in synonymy of Polydrusus (Polydrusus) fulvicornis fulvicornis (Fabricius, 1792): undulatus Gmelin, 1790: 1803 (Curculio) [RN]

p. 374, add IT to distribution of Polydrusus (Scythodrusus) inustus Germar, 1824 [Caldara]

p. 375, add "unjustified" before RN for prasinoides Bovie, 1907 in synonymy of Polydrusus (Scythodrusus) piliferus Hochhuth, 1847

p. 375, delete [HN] for prasinus Reitter, 1899 in synonymy of Polydrusus (Scythodrusus) piliferus Hochhuth, 1847

p. 378, add NARi to distribution of Brachysomus (Brachysomus) echinatus (Bonsdorff, 1785)

p. 378, add [unjustified RN] to hirsutulus Fabricius in synonymy of Brachysomus (Brachysomus) echinatus (Bonsdorff, 1785)

p. 381, add LU to distribution of Eusomus ovulum Germar, 1824

p. 382, add LU to distribution of Exomias mollicomus (Ahrens, 1812)

p. 382, add NARi to distribution of Exomias pellucidus pellucidus (Boheman, 1834)

p. 382, add LU to distribution of Exomias trichopterus (Gautier des Cottes, 1863)

p. 384, add IT to distribution of Pleurodirus (Pseudometallites) murinus (Gyllenhal, 1834) [Caldara]

p. 389, add CY to distribution of Sitona hispidulus (Fabricius, 1777)

p. 393, correct the genus of the type species of genus Geotragus Schoenherr to Geotragus and add under it:

brevidens Ren, Alonso-Zarazaga \& Zhang, 2013: 167 A: YUN

declivis Ren, Alonso-Zarazaga \& Zhang, 2013: 170 A: YUN

rugosus Ren, Alonso-Zarazaga \& Zhang, 2013: 173 A: YUN

p. 399, add:

genus Orthomias Faust, 1885e: 72 type species Orthomias seriatus Faust, 1885

notaexcavatus Gandhi \& Pajni, 1990: 37 A: SD

p. 399, add under Pachynotus:

kumaonensis Mahendiran \& Ramamurthy, 2013: 83 A: UP

mayarami Mahendiran \& Ramamurthy, 2013: 82 A: UP

p. 399, add HP to distribution of Pachynotus globicollis L. Redtenbacher, 1844

p. 403, add under Enaptorhinus:

pseudocrocodylus Han \& Zhang, 2013: 125 A: SC SHN

p. 403, add SC to distribution of Enaptorhinus convexiusculus Heller, 1930 
p. 403, delete SC from distribution of Enaptorhinus sinensis G.R. Waterhouse, 1853

p. 407, add SP to distribution of Cycloderes (Cycloderes) depilis (Fairmaire, 1863)

p. 413, transfer the genera and species under the heading "subfamily Entiminae, taxa incertae sedis" and "subfamily Entiminae, nomen dubium" to p. 423, before subfamily Hyperinae

p. 417, add LU to distribution of Cathormiocerus spinosus (Goeze, 1777) and add to its synonymy: sulcatus Schrank, 1781: 126 (Curculio) [HN]

p. 417, transfer genus Massimiellus Borovec, 2009 and its species to tribe Holcorhinini

p. 418, add LU to distribution of Romualdius angustisetulus (V. Hansen, 1915)

p. 418, add FR(Corse) to distribution of Romualdius peyerimhoffi (Formánek, 1910)

p. 420, delete Trachyphloeus (Trachyphloeus) difformis Formánek

p. 420, add TU to distribution of Trachyphloeus (Trachyphloeus) godarti Seidlitz, 1868 and add in synonymy: difformis Formánek, 1907b: 161

p. 420, add LU to distribution of Trachyphloeus (Trachyphloeus) heymesi Hubenthal, 1934

p. 421, add under Trachyphloeus subgenus Trachyphloeus:

oranensis Borovec, 2013: 242 N: AG MO svatavae Borovec, 2013: 244 N: AG TU tarunahensis Borovec \& Weill, 2013: 2 N: LB

p. 422, transfer Trachyphloeus cruciatus Seidlitz under genus Holcophloeus Borovec \& Meregalli in Holcorhinini

p. 423, delete carinatus O.F. Müller in synonymy of Tropiphorus elevatus (Herbst, 1795) (a misidentification of Curculio carinatus DeGeer, 1775)

p. 423, add under Tropiphorus: [Caldara \& Alonso-Zarazaga]

fiorii Pedroni, 2006: 25 E: IT

p. 423, place Tropihorus norici Yunakov after T. moldavicus Penecke

p. 423, add under Tropiphorus: paulae Pedroni, 2012b: 99 E: IT

p. 423, delete the genus Vitavitus Kissinger, 1974 and its species $V$. thulius (transferred under genus Lepidophorus Kirby)

p. 424, add FI NT to distribution of Brachypera (Antidonus) dauci (Olivier, 1807) [Skuhrovec]

p. 424, add E: MA to distribution of Brachypera (Antidonus) parvithorax (Desbrochers des Loges, 1896)

p. 424, add BH NT to distribution of Brachypera (Antidonus) vidua (Gené, 1837) [Skuhrovec]

p. 424, add LT LU to distribution of Brachypera (Antidonus) zoilus (Scopoli, 1763) [Skuhrovec, Alonso-Zarazaga]

p. 425, add MA to distribution of Brachypera (Brachypera) fallax (Capiomont, 1868) p. 426, add NARi to distribution of Coniatus (Bagoides) splendidulus (Fabricius, 1781)

p. 426, add in synonymy of Donus Jekel, 1865: Altaiodonus Legalov, 1999e: 189 [RN] type species Glanis cupreus Legalov, 1997

p. 427, add AL to distribution of Donus cyrtus (Germar, 1821) [Skuhrovec]

p. 427, add under Donus Jekel, 1865: [Skuhrovec] diversisquamosus Legalov, 2012a: 161 (Asiodonus) A: UZ

p. 428, add LU to distribution of Donus intermedius intermedius (Boheman, 1842)

p. 428, add under Donus Jekel, 1865: [Skuhrovec] knutelskyi Legalov, 2012a: 157 (Asiodonus) A: FE

p. 428 , add LU to distribution of Donus ovalis (Boheman, 1842)

p. 429, add under Donus Jekel, 1865: [Skuhrovec] potanini Legalov, 2012a: 160 (Asiodonus) A: GAN shokhrini Legalov, 2012a: 160 (Asiodonus) A: FE streltzovi Legalov, 2012a: 158 (Asiodonus) A: FE tshernyshevi Legalov, 2012a: 161 (Asiodonus) A: KI

p. 429, add SZ to distribution of Donus segnis (Capiomont, 1868) [Skuhrovec]

p. 429, add under Eremochorus subgenus Eremochorus: [Skuhrovec] arazantauensis Legalov, 2012a: 164 A: KZ

p. 429, add in synonymy of Eremochorus (Eremochorus) concinnus (Boheman, 1842):

praecomatus Łomnicki, 1894: 87 (Hypera)

p. 430, add under Eremochorus subgenus Eremochorus: [Skuhrovec]

lebedevi Legalov, 2012a: 165 A: KZ voruchensis Legalov, 2012a: 164 A: TD

p. 431, add NR to distribution of Hypera (Dapalinus) fornicata (Penecke, 1928) [Skuhrovec]

p. 431, delete Altaiodonus Legalov from synonymy of Eririnomorphus Capiomont, 1868

p. 431, correct type species of Zaslavskypera Legalov to Curculio conmaculatus

p. 432, add LA NT to distribution of Hypera (Hypera) denominanda (Capiomont, 1868) [Skuhrovec]

p. 433, add LU to distribution of Hypera (Hypera) ononidis (Chevrolat, 1863)

p. 433, add FI to distribution of Hypera (Hypera) plantaginis (DeGeer, 1775) [Skuhrovec]

p. 433, correct bimaculatus Marsham, denigratus Gmelin and parcus Gyllenhal in synonymy of Hypera (Hypera) postica (Gyllenhal, 1813) to bimaculata, denigrata and parca, respectively

p. 433, add [NO] to denigrata Gmelin in synonymy of Hypera (Hypera) postica (Gyllenhal, 1813)

p. 434, add LU to distribution of Hypera (Hypera) venusta (Fabricius, 1781)

p. 434, the description of striata Herbst, 1783 [in synonymy of Hypera (Kippenbergia) arator (Linnaeus, 1758)] started on p. 72, but ended on p. 73, published in 1784, so correct year and page to 1784: 73 , under Art. 10.1.1 of the Code 
p. 435, correct date for Hypera deserta (Panzer) to 1796

p. 435, add LU to distribution of Limobius borealis borealis (Paykull, 1792)

p. 435, add PT to distribution of Limobius mixtus (Boheman, 1834) [Skuhrovec]

p. 435, add to Macrotarrhus subgenus Macrotarrhus: bajtenovii Zaslavskij, 1980: 128 A: KZ

p. 439 , add LU to distribution of Bothynoderes affinis (Schrank, 1781)

p. 439, add [RN] to albidus Fabricius in synonymy of Bothynoderes affinis (Schrank, 1781):

p. 439, add in synonymy of Bothynoderes affinis (Schrank, 1781):

roseus Contarini, 1847: 189 (Lixus)

p. 440, add LU and NARi to distribution of Cleonis pigra (Scopoli, 1763)

p. 440, delete fuscata Gmelin and transversofasciata Goeze in synonymy of Cleonis pigra (Scopoli, 1763)

p. 441, add in synonymy of Coniocleonus (Angarocleonus) zherichini Ter-Minasian \& Korotyaev, 1977:

stenothorax R.S. Anderson, 1988: 465 (Stephanocleonus)

p. 441, add LU SL to distribution of Coniocleonus (Augustecleonus) nebulosus (Linnaeus, 1758) and add as a synonym:

iners Scopoli, 1763: 24 (Curculio)

p. 441, add LU to distribution of Coniocleonus (Augustecleonus) turbatus (Fåhraeus, 1842)

p. 441, add E: ST to distribution of Coniocleonus (Coniocleonus) schoenherri (Gebler, 1830)

p. 441, add CZ LU to distribution of Coniocleonus (Plagiographus) cicatricosus (Hoppe, 1795)

p. 441, add CZ to distribution of Coniocleonus (Plagiographus) excoriatus (Gyllenhal, 1834)

p. 443, add LU to distribution of Cyphocleonus dealbatus (Gmelin, 1790)

p. 443, add LU to distribution of Cyphocleonus trisulcatus (Herbst, 1795)

p. 445, add under Leucochromus Motschulsky, 1860: consobrinus Ter-Minasian, 1972b: 543 A: KZ

p. 446, add [DA] after pasticus Germar in synonymy of Leucophyes pedestris (Poda, 1761) (Dieckmann [1982] excluded this name from the synonymy)

p. 447, replace authorship and page for Mecaspis alternans to Hellwig and 116, and place in synonymy [see New Acts]:

alternans Herbst, 1795: 85 (Curculio)

p. 448, add CZ to distribution of Pachycerus segnis (Germar, 1824)

p. 455, add UP to distribution of Xanthochelus blumeae Marshall, 1938

p. 456, delete Xanthochelus ewersmanni (Fåhraeus, 1842 ) and its synonym

p. 456, add under Xanthochelus:

omogeron Herbst, 1797: 11 (Curculio) A: KZ ewersmanni Fåhraeus, 1842: 58 (Cleonus)
The first name is incorrectly marked as a homonym and, although it meets the requirements of Art. 23.9.1.1 of the Code, the second does not meet those of Art. 23.9.1.2. I am following here the Principle of Priority.

p. 456, add under Bangasternus: iranensis Talamelli, 2013: 233 A: IN

p. 458, add under Larinus subgenus Cryphopus: berti Gültekin \& Alonso-Zarazaga, 2013: 22 N: $\mathrm{MO}$

p. 459, correct year for mutabilis Host to 1790 [in synonymy of Larinus (Larinus) latus (Herbst, 1783)]

p. 460, add CY to distribution of Larinus (Larinus) ursus (Fabricius, 1792)

p. 461, add [HN] to marginicollis Petri in synonymy of Larinus (Larinomesius) canescens Gyllenhal, 1835

p. 461, add in synonymy of Larinus (Larinomesius) scolymi (Olivier, 1807):

teres Hellwig, 1795: 118 (Curculio) [HN]

p. 463, add SP to distribution of Larinus (Phyllonomeus) leuzeae Fabre, 1870

p. 463, add LU to distribution of Larinus (Phyllonomeus) turbinatus Gyllenhal, 1835

p. 463, transfer Larinus afghanicus Ter-Minasian, badghysensis Ter-Minasian, brevirostris Hochhuth and capiomonti Faust to the new genus Nefis below

p. 464, transfer Larinus exclusus Faust, liliputanus Faust, ochroleucus Capiomont, pachyrrhinus Petri, reitteri Faust and turcmenus Iablokoff-Khnzorian to the new genus Nefis below

p. 464, delete cylindricus Fabricius, 1787 in synonymy of Lixus (Callistolixus) cylindrus (Fabricius, 1781), an incorrect subsequent spelling, not a RN

p. 465, add under Lixus subgenus Compsolixus: erysimi Stüben, 2013a: 2 N: CI(Gran Canaria)

p. 465 , correct spelling and page of cylindrus Herbst in synonymy of Lixus (Dilixellus) bardanae (Fabricius, 1787) to cylindricus and 71

p. 467, add CY to distribution of Lixus (Epimeces) filiformis (Fabricius, 1781)

p. 467, add SZ to distribution of Lixus (Epimeces) scolopax Boheman, 1835

p. 468, add CY to distribution of Lixus (Eulixus) iridis Olivier, 1807

p. 468, add [HN] to cylindrus Hoffmann, 1963 under synonymy of Lixus (Eulixus) isfahanensis Gültekin, 2010

p. 468, add in synonymy of Lixus (Eulixus) lateralis (Panzer, 1789):

tabidus Olivier, 1791: 534 (Curculio) [unjustified $\mathrm{RN}]$

p. 468, add FUJ GUX SCH SHG ZHE to distribution of Lixus (Eulixus) obliquivittis Voss, 1937 [Ren]

p. 469, place Lixus (Eulixus) tricolor Capiomont, 1876 in synonymy of Lixus (Eulixus) trichromus Alonso-Zarazaga, nom. nov. [see New Acts] 
p. 469 , add $[\mathrm{HN}]$ to tricolor Capiomont, 1876 in synonymy of Lixus (Eulixus) trichromus AlonsoZarazaga, nom. nov.

p. 469, add to synonymy of Lixus (Lixus) paraplecticus (Linnaeus, 1758):

phellandrii Linnaeus, 1764: 357 (Curculio)

p. 469, add [HN] to phellandrii DeGeer in synonymy of Lixus (Lixus) paraplecticus (Linnaeus, 1758):

p. 470, add CY to distribution of Lixus (Ortholixus) vilis (Rossi, 1790)

p. 470, add CY to distribution of Lixus (Phillixus) scabricollis Boheman, 1842

p. 471, correct year for Lixus tricolor (Scopoli) to 1771

p. 471, add under Lixini:

genus Nefis Gültekin, 2013: 3 type species Larinus brevirostris Hochhuth, 1851

afghanicus Ter-Minasian, 1988b: 119 (Larinus) A: AF

attilai Gültekin, 2013: 24 A: TR

brevirostris Hochhuth, 1851: 86 (Larinus) E: AB

AR A: IN TR

reitteri Faust, 1889e: 205 (Larinus)

capiomonti Faust, 1885b: 169 (Larinus) A: KI KZ

RU TD TM UZ

kabakovi Gültekin, 2013: 10 A: AF

korotyaevi Gültekin, 2013: 11 A: TR

liliputanus Faust, 1890d: 259 (Larinus) A: CH IN

KI TM UZ

exclusus Faust, 1891b: 118 (Larinus)

ochroleucus Capiomont, 1874a: 75 (Larinus) E:

AB AR A: IN KI NW TD TM TR UZ

pachyrrhinus Petri, 1907a: 79 (Larinus) A: TM

badghysensis Ter-Minasian, 1982: 43 (Larinus)

turcmenus Iablokoff-Khnzorian, 1990a: 131 (Larinus)

p. 472, add LU to distribution of Magdalis (Edo) ruficornis (Linnaeus, 1758)

p. 473, add CY to distribution of Magdalis (Laemosaccidius) scutellaris K. Daniel, 1903

p. 473, add LU to distribution of Magdalis (Magdalis) duplicata Germar, 1819

p. 473, add LU to distribution of Magdalis (Magdalis) frontalis (Gyllenhal, 1827)

p. 473, add LU to distribution of Magdalis (Magdalis) memnonia (Gyllenhal, 1837)

p. 473, add LU to distribution of Magdalis (Magdalis) nitida (Gyllenhal, 1827)

p. 473, correct page for Magdalis (Magdalis) phlegmatica (Herbst, 1797) to 6

p. 473, add GB to distribution of Magdalis (Magdalis) rufa Germar, 1824

p. 474, add LU to distribution of Magdalis (Magdalis) violacea (Linnaeus, 1758)

p. 474, delete assimilis Herbst in the synonymy of Magdalis (Magdalis) violacea (Linnaeus, 1758) (it has been suppressed in Opinion 1529, ICZN 1989)

p. 474, add to synonymy of Magdalis (Odontomagdalis) armigera (Geoffroy, 1785): cerasi Gmelin, 1790: 1744 (Curculio) [HN]

p. 474, add LU to distribution of Magdalis (Panopsis) flavicornis (Gyllenhal, 1836)

p. 474, add LU to distribution of Magdalis (Panus) barbicornis (Latreille, 1804)

p. 474, add LU to distribution of Magdalis (Porrothus) cerasi (Linnaeus, 1758)

p. 475, add to genus Magdalis, nomina dubia: ulmi Schrank, 1798: 488 (Curculio) [HN]

p. 476, add under Niphadonyx: affinis Meregalli, 2013: 20 A: QIN alternans Meregalli, 2013: 33 A: SCH amplithorax Meregalli, 2013: 59 A: SCH bufo Meregalli, 2013: 81 A: XIZ canaliculatus Meregalli, 2013: 76 A: BT SD costipennis Meregalli, 2013: 61 A: SCH daxuensis Meregalli, 2013: 35 A: $\mathrm{SCH}$ dentipes Meregalli, 2013: 104 A: NP dequenensis Meregalli, 2013: 31 A: YUN fabbrii Meregalli, 2013: 43 A: SCH fausti Meregalli, 2013: 83 A: XIZ gracilis Meregalli, 2013: 86 A: YUN granulipennis Meregalli, 2013: 39 A: $\mathrm{SCH}$ herzogianus Meregalli, 2013: 106 A: NP himachalensis Meregalli, 2013: 72 A: HP himalayanus Meregalli, 2013: 74 A: UP inconspicuus Meregalli, 2013: 84 A: AP XIZ iuliae Meregalli, 2013: 37 A: YUN kalabi Meregalli, 2013: 54 A: GAN karnaliensis Meregalli, 2013: 99 A: NP khamensis Meregalli, 2013: 45 A: SCH kozlovi Meregalli, 2013: 23 A: QIN SCH laevisculptus Meregalli, 2013: 27 A: SCH XIZ laurae Meregalli, 2013: 90 A: NP limnophilus Meregalli, 2013: 21 A: XIZ lingshanicus Meregalli, 2013: 47 A: SCH liubeii Meregalli, 2013: 30 A: YUN loevior Hustache, 1928a: 16 (Heteronyx) A: HP UP

parallelus Meregalli, 2013: 68 A: AP pustulifer Meregalli, 2013: 42 A: $\mathrm{SCH}$ reticollis Meregalli, 2013: 78 A: BT rugosus Meregalli, 2013: 66 A: NP schawalleri Meregalli, 2013: 89 A: NP schmidti Meregalli, 2013: 79 A: NP shaluiensis Meregalli, 2013: 25 A: SCH shimlae Meregalli, 2013: 96 A: HP shuicus Meregalli, 2013: 51 A: SCH sichuanus Meregalli, 2013: 40 A: SCH sympatricus Meregalli, 2013: 75 A: AP tara Meregalli, 2013: 87 A: XIZ tryznai Meregalli, 2013: 52 A: $\mathrm{SCH}$ tuberculosus Meregalli, 2013: 49 A: SCH xinuluoi Meregalli, 2013: 57 A: YUN yunnanensis Meregalli, 2013: 55 A: YUN

p. 476, add XIZ to distribution of Niphadonyx castaneus (Voss, 1956)

p. 476, delete HP KA from distribution of Niphadonyx ferus (Faust, 1887) 
p. 476, delete loevior Hustache, 1928 from synonymy under Niphadonyx ferus (Faust, 1887)

p. 476, add PA to distribution of Niphadonyx foveatus Pajni \& Sood, 1983

p. 476, add PA to distribution of Niphadonyx kashmirensis (Formánek, 1922)

p. 476, add SD to distribution of Niphadonyx martensi Zherikhin, 1987

p. 476, add SD to distribution of Niphadonyx nepalensis (Voss, 1970)

p. 479, add SB to distribution of Hylobius (Callirus) transversovittatus (Goeze, 1777)

p. 481, replace E: with A: in distribution of Deretiosopsis nigrisetis Morimoto, 1988

p. 481, swap placements of Deretiosus ishigakianus Morimoto, 1988 and D. grisescens Voss, 1958

p. 482, add to synonymy of Lepyrus capucinus (Schaller, 1783):

binotatus Paykull, 1792: 35 (Curculio)

nigricans Gmelin, 1790: 1747 (Curculio) [unjustified $\mathrm{RN}]$

p. 482, add [HN] to binotatus Rossi in synonymy of Lepyrus capucinus (Schaller, 1783)

p. 482, add in synonymy of Lepyrus nordenskioldi nordenskioldi Faust, 1887: frigidus Łomnicki, 1894: 86

p. 483 , replace $\mathbf{E}$ : with $\mathbf{N}$ : in distribution of Alcidodes willcocksi (Pic, 1913)

p. 487, add under Leiosoma:

alpinum Pedroni, 2012a: 78 E: IT

angelinii Pedroni, 2012a: 85 E: IT

colonnellii Pedroni, 2012a: 87 E: IT

dardagnense Pedroni, 2012a: 80 E: IT

fiscellense Pedroni, 2012a: 83 E: IT

hernicum Pedroni, 2012a: 81 E: IT

p. 493, correct spelling for Pissodes (Pissodes) cheni to chenae

p. 495, add NARi to distribution of Trachodes (Trachodes) hispidus (Linnaeus, 1758)

p. 497, before the subfamily Orobitidinae, insert a section "subfamily Molytinae, incertae sedis" and add the following:

genus Siraton Hustache, 1934: 250 type species Siraton devillei Hustache, 1934 (= Tranes internatus Pascoe, 1870)

Melanotranes Zimmerman, 1994: 696 type species

Tranes internatus Pascoe, 1870

internatus Pascoe, 1870a: 199 (Tranes) E: IT(I. Elba) AUR

devillei Hustache, 1934: 250

Probably an accidental introduction, not collected in the following 80 years.

p. 497, add to synonymy of Orobitis cyanea (Linnaeus, 1758):

globosa Fabricius, 1775: 132 (Curculio) [HN]

p. 498, transfer Curculio alneti Schrank to synonymy of

Dorytomus (Dorytomus) tortrix (Linnaeus, 1760)

p. 498, add [HN] to Curculio aurifer Villers, 1789

p. 498, add Curculio caeruleus Villers, 1789b: 288 [HN] p. 498, delete Curculio centaureae Giorna, a later use of Curculio centaureae Allioni

p. 498, delete Curculio chrysopterus Schrank

p. 498, correct year and page for Curculio corticinus Giorna to 1792: 438

p. 498, delete Curculio crassus Giorna, a later use of Curculio crassus Allioni

p. 498, add in synonymy of Curculio cypri Linnaeus, 1766:

Curculio cypri Gmelin, 1790: 1801 [HN]

p. 499, delete Curculio fasciatus O.F. Müller, 1776 (already in synonymy of Bothynoderes affinis)

p. 499, delete Curculio haematopus Schrank, 1798 (already in synonymy of Otiorhynchus tenebricosus (Herbst, 1784))

p. 499, add Curculio hispidus Brahm, 1790: 20 [HN] E: GE

p. 499, transfer Curculio iners Scopoli to synonymy of Coniocleonus (Augustecleonus) nebulosus (Linnaeus, 1758)

p. 499, add Curculio infidus Rossi, 1792: 38 [HN] E: IT

p. 499, transfer Curculio latro Schrank to synonymy of Dorytomus (Dorytomus) tortrix (Linnaeus, 1760)

p. 499, correct authorship and year of Curculio longicornis Florencourt to Meyer \& Florencourt, 1795

p. 499, add Curculio muricatus Goeze, 1777: 412

[HN] E: FR and its synonym Curculio murinus Geoffroy, 1785: 124 [HN]

p. 499, delete Curculio ovalis Linnaeus, 1760

p. 499, add Curculio papillosus Piller \& Mitterpacher, 1783: 34 E: CR

p. 500, add [NO] to Curculio piceus Wulfen, 1763

p. 500, add Curculio quadratus Goeze, 1777: 411 E:

FR and its synonym Curculio quadrilis Geoffroy, 1785: 122

p. 500, add Curculio rhei Herbst, 1784: 78 E: GE

p. 500, delete Curculio salicinus Schrank, 1781 and Curculio scabriculus Linnaeus, 1771

p. 499, transfer Curculio sulcatus Schrank to synonymy of Cathormiocerus spinosus (Goeze, 1777)

p. 500, add in synonymy of Curculio undatus Gmelin, 1790:

Curculio undulatus Olivier, 1791: 562 [RN, HN]

p. 500, add Curculio vanellus Herbst, 1784: 79 E: GE

p. 500, add Curculio varians Olivier, 1791: 563 [RN]

E: "Russia australi" (not a homonym) and add as its synonyms Curculio variegatus Goeze, 1777: $374[\mathrm{HN}]$ and Curculio varius Gmelin, 1790: $1756[\mathrm{HN}]$

p. 500, correct year for Curculio variegatus Scopoli to 1771

p. 500, delete Curculio variegatus Goeze, 1777 and its synonyms

p. 501, delete [HN] after Curculio varians Olivier, 1791 and use as the valid name for the species; its supposed prior homonym, Curculio varians Gmelin, 1790 is just an incorrect subsequent spelling for Curculio varius Fabricius, 1775 and is unavailable 
p. 504, add reference:

Alonso-Zarazaga M.A. 2013b: Moreiba gen. n., a new Canarian genus in Laparocerini (Coleoptera, Curculionidae). ZooKeys 333: 45-54.

p. 505, add reference:

Anderson R.S. 1987: Systematics, phylogeny and biogeography of the New World weevils traditionally of the tribe Cleonini (Coleoptera: Curculionidae: Cleoninae). Quaestiones Entomologicae 23: 431-709.

p. 512, add reference:

Bajtenov M.S. 1983: Neue und seltene Arten von Rüsselkäfern (Col., Curculionidae) aus Sibirien und dem Fernen Osten. Entomologische Nachrichten und Berichte 27(1): 18-20.

p. 516, correct year for the second reference by Białooki P. \& Szypula J. to 2006b [Pelletier]

p. 519, add references:

Borovec R. 2013: A review of the North African species group Trachyphloeus godarti with descriptions of two new species from Morocco, Algeria and Tunisia (Coleoptera: Curculionidae: Entiminae). Studies and Reports Taxonomical Series 9(2): 235-248.

Borovec R. \& Germann C. 2013: Two new species of Polydrusus (Polydrusus) from Turkey, Iran and Greece (Coleoptera: Curculionidae: Entiminae: Polydrusini). Zootaxa 3693(1): 75-84.

Borovec R. \& Meregalli M. 2013: [new taxa]. In: Borovec R., Menardo F. \& Meregalli, M.: A new genus of Entiminae from North Africa, supported by a phylogenetic analysis (Coleoptera: Curculionidae: Entiminae). Zoological Journal of the Linnean Society 167(2): 243-258.

p. 520, add reference:

Borovec R. \& Weill P. 2013: First discovery of Trachyphloeini in Libya - Trachyphloeus tarunahensis sp. (Coleoptera: Curculionidae: Entiminae: Trachyphloeini). Studies and Reports Taxonomical Series 9(1): 1-6.

p. 522, correct pages for Brisout de Barneville H. 1862 to 625-636; this part appeared on the third fascicle to be dated 10 December 1862, while pages 637-668 appeared on the fourth fascicle, which is to be dated 11 March 1863; some names are available from the key in the first part, and the pages have been corrected above

p. 522, add reference:

Brisout de Barneville H. 1863: Monographie du genre Gymnetron. [Cont.]. Annales de la Société entomologique de France (4) 2(4): 637-668.

p. 522, correct year for Brisout de Barneville, $\mathrm{H}$. 1865 b to 1866 , fascicule 4 (including pp. 619-626) appeared on 26 May 1866

p. 531, add reference:

Colonnelli E. 2013: A new species of Parascythopus Desbrochers from Syria (Coleoptera, Curculionidae). Fragmenta Entomologica 45(1-2): 173-179. p. 532, add reference:

Contarini N.B. 1847: Notizie sulla fauna terrestre e particolarmente sulla ornitologia del Veneto estuario con cenno sul passagio degli ucelli e della caccia. Pp. 157-191. In: Anonym: Venezia e le sue lagune. Vol. 2. Venezia, Antonelli, [1]+594; 1+516; 1-159; - 2 (1) 157-191.

p. 535 , add reference:

Davidian G.E. \& Korotyaev B.A. 2012: Novye dannye po sistematike, rasprostraneniû i èkologii žukov-dolgonosikov gruppy Otiorhynchus morosus Fst. (Coleoptera, Curculionidae). Entomologičeskoe Obozrenie 91(2): 352-371.

p. 536, add reference: [Pierotti]

Delaunay L. \& Melle A. 2013: Descriptions de six nouvelles Meira J. du Val, 1852 des Cévennes (France méridionale) et note sur Meira sedilloti Ch. Brisout, 1882, bona species (Coleoptera Curculionidae Entiminae). Faunitaxys 1 (1): 1-16. p. 542, add reference:

Diotti L. \& Caldara R. 2013: Descrizione di Archarius ziliolii, nuova specie di Italia e Svizzera affine ad A. crux (Fabricius) (Coleoptera, Curculionidae). Giornale Italiano di Entomologia 13(58): 251-258.

p. 545, delete the reference for Fabricius, 1781b; it has no weevil species

p. 545, add reference:

Fabricius J.C. 1782: Species insectorum exhibentes eorum differentias specificas, synonyma, auctorum, loca natalia, metamorphosin adiectis observationibus, descriptionibus. Appendix. Hamburgi \& Kilonii: Impensis Carol. Ernest. Bohnii. Pp. 495-517.

p. 550, add reference:

Faust J. 1885e: Africanische Rüsselkäfer. Entomologische Nachrichten 11(5): 65-76.

p. 553, delete reference to Florencourt K. C. von. 1796 p. 557, add reference:

Gandhi S.S. \& Pajni H.R. 1990: The first record of genus Orthomias Faust and report of a new species from India. Geobios new Reports 9(1): 37-39.

p. 559, add reference:

Germann C. 2013: A review of Dichorrhinus Desbrochers, 1875 (Coleoptera, Curculionidae) with two new species from Greece and Turkey, and from Cyprus. European Journal of Taxonomy 46: 1-13.

p. 561, delete reference to Giorna, 1791; according to Pirotta (1879), this book appeared in parts in different years: '1779-1793. Giorna. Calendario entomologico. Torino, 1779-1793. Il figlio di [Michele] Spirito Giorna conosciuto col nome di Giorna il figlio [Giuseppe Giorna], pubblicava questo suo Calendario ad intervalli cioè nel 1779 [1789!], nel 1791 e nel 1792 e 1793 nel Giornale scientifico-letterario di Torino, Vol. 2, p. 66 e 376 e nella Biblioteca Oltremontana e Piemontese, 
vol. IV, p. 45 del 1791, vol. I, p. 101 e 233, vol. II, p. 212, vol. III, p. 215 del 1792 e vol. I, p. 139, vol. III, p. 149, 158, 169 del 1793'. However, much before, Millin (1795), q.v., stated that the book appeared after the parts in the journals, most particularly those which appeared in the Biblioteca Oltremontana Piemontese and its ensuing series Biblioteca dell'anno. A cursory checking of the text shows that the book has several improvements for readability over the journal parts, including changes in the index and correction of errors, although the general typesetting has been conserved, coming from the same printer. Moreover, on p. 142, Dermestes dubius Rossi, 1792 is mentioned. Consequently, it is to be concluded that the date in the frontispiece of the book is a beginning date for the series of articles, and not a publication date for the book, and that this was published after the parts appeared in the journals.

p. 561, add reference:

Giorna G. 1792: Calendario degl'insetti. Biblioteca dell'anno M.DCC.XC.II(1): 233-251.

p. 564, add reference:

Gültekin L. 2013: A new weevil genus Nefis gen. nov (Coleoptera: Curculionidae: Lixinae): systematics and taxonomic revision. Journal of Insect Biodiversity 1(3): 1-51.

Gültekin L. \& Alonso-Zarazaga M.A. 2013: Larinus berti sp n. (Coleoptera, Curculionidae, Lixinae) from North Africa. ZooKeys 342: 21-28.

p. 566, add reference:

Han K. \& Zhang R.-Zh. 2013: Taxonomic note on Korean Enaptorhinus G.R. Waterhouse (Coleoptera: Curculionidae: Entiminae) with a new species and a new record from Korea. Entomological Research Bulletin 29(2): 124-127.

p. 567, add reference:

Heller K.M. 1915b: Die mir bekannten DermatodesArten (Col. Curculionidae). Entomologische Mitteilungen 4(7-9): 206-226.

p. 572, correct year for Host, 1791 to 1790, published 18 th April

p. 572, add reference:

Huang J.H., Yoshitake H. \& Zhang R.-Zh. 2013: [new taxa]. In: Huang J.H., Yoshitake H., Zhang R.-Zh. \& Ito M.: Taxonomic review of the genus Rhinoncomimus (Coleoptera: Curculionidae: Ceutorhynchinae) with description of a new species from Yunnan, China. Zootaxa 3750(2): 143-166.

p. 574, add reference:

Hustache A. 1929b: Curculionidae. Voyage de Ch. Alluaud et R. Jeannel en Afrique Orientale (1911-1912). Résultats scientifiques, Coleoptera 30: $365-562+$ pl. X-XI.

p. 575, add reference:

Hustache A. 1932e: Curculionides nouveaux de I'Afrique Équatoriale (IIe partie). Sbornik entomologického oddelení národního Musea v Praze 10: 28-109. p. 580, add reference:

Kojima H. \& Morimoto K. 1993: On systematic position of the genus Apionodes Marshall (Coleoptera, Curculionidae), with description of a new species from Taiwan. Esakia 33: 87-94.

p. 585, add references:

Korotyaev B.A. 2011b: Novye vidy žukovdolgonosikov roda Pseudorchestes (Coleoptera, Curculionidae) iz Central'noj Palearktiki. Žoologičeskij Žurnal 90(2): 243-248.

Korotyaev B.A. 2012: A new species of the weevil genus Ceutorhynchus Germar (Coleoptera: Curculionidae) from China. Zoosystematica Rossica 22(1): 82-86.

p. 586, add references:

Kumar D. \& Pajni H.R. 1995: First record of genus Telephae Pascoe (Isorhynchini: Zygopinae: Curculionidae: Coleoptera) from India with the description of new species. Annals of Entomology (Dehra Dun) 13(2): 19-21.

Kumar D. \& Pajni H.R. 1996: Four new species of genus Lobotrachelus Schonherr from India (Zygopinae: Curculionidae: Coleoptera). Hexapoda (Insecta Indica) 8(2): 107-116.

p. 587, add reference:

Kwon Y.J. \& Lee S.M., 1981: Curculioninae of Korea (III) (Coleoptera: Curculionidae). Korean Journal of Entomology 11(2): 50.

p. 588, add references: [Skuhrovec]

Legalov A.A. 2012a: New weevil species of the tribe Hyperini (Coleoptera, Curculionidae) from Asia. Euroasian Entomological Journal 11(2): 157-166.

Legalov A.A. 2012b: Annotirovannyj spisok listovyh dolgonosikov triby Hyperini (Coleoptera, Curculionidae) fauny Rossii. Trudy Russkogo èntomoločeskogo obŝestva 83(1): 121-132.

Legalov A.A. 2012c: Novye dannye o tribe Hyperini (Coleoptera, Curculionidae) Azii. Amurskij zoologičeskij žurnal 4(2): 154-156.

p. 588, add reference:

Lemaire J-M., Ponel P. \& Alziar G. 2012: Les Curculionides cavernicoles de région niçoise, France. III. Description d'Otiorhynchus (Lixorrhynchus) monoecirupis n. sp. de Monaco (Coleoptera, Curculionidae, Entiminae). Bulletin de la Société entomologique de France 117(3): 283-287.

p. 589, add reference:

Linnaeus C. 1764: Noxa Insectorum sub praesidio D:n. Doct. Caroli Linnaei, proposita a Michael A. Baeckner, helsingo. Upsaliae 1752, Decemb. 18. Amoenitates Academicae seu dissertationes variae Physicae, medicae botanicae antehac seorsim editae, nunc collectae et auctae cum tabulis aeneis. Vol. 3. Holmiae, Sumtu \& literis Laurentii Salvii. Pp. 335-362.

p. 590, correct in Łomnicki A.M. 1881 the reference (Kosmos Lwów) to Kosmos (Lwów) 
p. 590, add reference:

Łomnicki A.M. 1894: Pleistoceńskie owady z Borysławia. (Fauna pleistocenica insectorum Boryslaviensium). Museum imienia Dzieduszyckich we Lwowie 4: 1-116, pl. I-IX.

p. 591, add reference at the bottom of the page: [Machado]

Machado A. 2012: Nuevos taxones de Laparocerus Schoenherr, 1834 de la isla de Gran Canaria (Coleoptera, Curculionidae, Entiminae). Boletín de la Sociedad Entomológica Aragonesa 51: 5-46. p. 595, add references:

Magrini P., Abbazzi P. \& Petrioli A. 2013: Neumatora annamariae n. sp. dell'Isola di Lampedusa (Isole Pelagie, Sicilia) (Coleoptera, Curculionidae, Cossoninae). Giornale Italiano di Entomologia 13(58): 361-374.

Mahendiran G. \& Ramamurthy V.V. 2013: The weevil genus Pachynotus Redtenbacher (Coleoptera: Curculionidae: Entiminae) from India. Oriental Insects 47(1): 76-85.

p. 598, correct title of Marshall G.A.K. 1944a to: On the genera of the tribe Cyphicerini (Col., Curc.).-I.

p. 598, correct title of Marshall G.A.K. 1994c to: On the genera of the tribe Cyphicerini (Col., Curc.).-II.

p. 601, add reference:

Meregalli M. 2013: A review of Niphadonyx a high altitude weevil genus of the Himalayas and North-West China (Coleoptera Curculionidae Molytinae). Memoirs on Biodiversity 2: 1-176.

p. 602, add reference (first volume recorded as being sold in the Leipzig Easter Fair 1795):

Meyer F.A.A. \& Florencourt K.C. von. 1795: [new taxon]. In: Florencourt K.C. von.: Verzeichniss der Insekten Göttingischer Gegend. Zoologisches Archiv (Meyer) 1 [1796]: 197-244.

p. 607 , add reference:

Nasreddinov H.A. 1978d: Novyj vid žukovdolgonosikov roda Myllocerinus Rtt. (Coleoptera, Curculionidae) iz Tadžikistana. Trudy Zoologičeskogo Instituta Akademii Nauk SSSR 71: 57-58.

Notsu Y. 2013: Three new species of Curculionine weevils from Taiwan, with a list of all the known Taiwanese species (Coleoptera, Curculionidae). Japanese Journal of systematic Entomology 19(2): 289-308.

p. 611, add reference:

Pajni H.R., Singh N. \& Gandhi S.S. 1994: On Indocurculio gen. nov. and its two new species from India (Curculioninae: Curculionidae: Coleoptera). Uttar Pradesh Journal of Zoology 14(2): 156-160.

p. 614, add references:

Pedroni G. 2006: Catalogo annotato delle specie di Dichotrachelus e Tropiphorus della collezione Fiori presente a Bologna con descrizione di Tropiphorus fioriin. sp. Bollettino dell'Associazone Romana di Entomologia 61(1-4): 21-28.
Pedroni G. 2012a: Le specie italiane del gruppo di Leiosoma scrobiferum con descrizione di sei specie nuove (Coleoptera, Curculionidae, Molytini). Bollettino del Museo Civico di Storia Naturale di Verona, Botanica Zoologia 36: 73-90.

Pedroni G. 2012b: Coleotteri apionidi e curculionidi dei piani subalpino e alpino nelle Dolomiti di Brenta (Trentino Alto Adige) con descrizione di Tropiphorus paulae n. sp. del piano subalpino (Coleoptera, Apionidae, Curculionidae). Bollettino del Museo Civico di Storia Naturale di Verona, Botanica Zoologia 36: 91-108.

p. 612, note the following dating for Pallas (1781, Icones Insectorum Part I):

Recorded in the Allgemeines Verzeichniss der Bücher, welche in der Frankfurter und Leipziger Ostermesse des 1781 Jahres entweder ganz neu gedruckt, oder sonst verbessert, wieder aufgeleget worden sind, auch inskünftige noch herauskommen sollen, p. 75. The Easter Fair started on 6-V1781 (Evenhuis, 2014).

p. 612, correct date for Panzer, 1797 to 1796

p. 615 , add reference:

Pelletier J. \& Borovec R. 2013: Contribution to the knowledge of the genus Seidlitzia Desbrochers des Loges, 1891 (Coleoptera, Curculionidae). Bulletin de la Société entomologique de France 118(3): 277-283.

p. 623 , add reference: [Caldara]

Pic M. 1901f: Notes diverses et diagnoses (8e article). L'Échange, Revue Linnéenne 17: 81-83.

p. 626, add references: [Pierotti]

Pierotti H. 2012a: Peritelini nuovi o interessanti della fauna w-mediterranea. XVIII. Nota nomenclatoriale.(Coleoptera, Curculionidae, Entiminae). Doriana 8(378): 1-4

Pierotti H. 2012b: Peritelini nuovi o interessanti della fauna w-mediterranea. XVII. Due nuove specie italiane del genere Meira Jacquelin du Val. (Coleoptera, Curculionidae, Entiminae). Doriana 8(380): 1-7.

Pierotti H. 2013a: Peritelini nuovi o interessanti della fauna w-mediterranea. XIX. Ancora due nuove specie italiane del genere Meira Jacquelin du Val.(Coleoptera, Curculionidae, Entiminae). Doriana 8(376): 1-5.

Pierotti H. 2013b: Peritelini nuovi o interessanti della fauna w-mediterranea. XXI. Nuovi Peritelini di Sardegna. (Coleoptera, Curculionidae, Entiminae). Doriana 8(383): 1-9.

Pierotti H. 2013c: New or interesting Peritelini of the Western Mediterranean fauna. XX. A novel Meira Jacquelin du Val, 1852 species from the Ligurian Alps. Zootaxa 3716(4): 595-598.

Pierotti H., Germann C. \& Braunert, C. 2013: New or interesting Peritelini of the West-Mediterranean fauna. XXIV. Two new Simmeiropsis Pierotti \& Bello, 2013 from Portugal (Coleoptera, Curculionidae, Entiminae). Zootaxa 3734(2): 273-280. 
p. 628, note the following dating for Reich (1797): recorded in the Göttingische Anzeiger für gelehrten Sachen, 1797: 1783, to be dated 11-XI-1797

p. 634, add reference:

Ren L., Alonso-Zarazaga M.A. \& Zhang, R.-Zh. 2013: Revision of the Chinese Geotragus Schoenherr with description of three new species (Coleoptera: Curculionidae: Entiminae). Zootaxa 3619(2): 161-182.

p. 641, line 16, replace Enterpriss with Entrepris

p. 643, correct year for Scopoli, 1772 to 1771, this work has been dated 22nd August 1771 by Evenhuis (1997)

p. 643, replace the entry for Seidlitz, 1865 with the following (appeared in 1865, the journal reference appeared in January 1866 (p. vi)):

Seidlitz G.C.M von. 1865. Monographie der Curculioniden-Gattung Peritelus Germ. Berlin: A.W. Schade. II +82+ [2] pp., 1 pl.

p. 647 , correct volume of Solari 1940a to 72(3)

p. 654, add reference:

Stüben P.E. 2013a: Lixus (Compsolixus) erysimi sp.n. von Gran Canaria (Kanarische Inseln) (Coleoptera: Curculionidae: Lixinae). Snudebiller 14(207): 1-5.

Stüben P.E. 2013b: Calacalles (Nanoacalles) lepensis sp. n. von La Gomera (Kanarische Inseln). (Coleoptera: Curculionidae: Cryptorhynchinae). Snudebiller 14(216): 1-5.

Stüben P.E. 2013c: [new taxon]. In: Stüben P.E., Schütte, A. \& Astrin, J.J.: Molecular phylogeny of the weevil genus Dichromacalles Stuben (Curculionidae: Cryptorhynchinae) and description of a new species. Zootaxa 3718(2): 101-127.

p. 656, add reference:

Talamelli F. 2013: Bangasternus iranensis n. sp from Iran (Insecta Coleoptera Curculionidae). Quaderno di Studi e Notizie di Storia Naturale della Romagna 37: 233-236.

p. 661, add reference:

Ugarte San Vicente I. \& Salgueira Cerezo F. 2009: Descripción de Strophosoma (Neliocarus) zarazagai sp. n. del Parque Natural de las Bárdenas Reales de Nafarroa/Navarra (norte de la Península Ibérica) (Coleoptera: Curculionidae: Entiminae). Heteropterus 9(2): 71-77.

p. 670 , add references:

Yang L.-J. \& Huang J.-H. 2013: [new taxon]. In: Yang L.-J., Huang, J.-H., Zhang R.-Zh. \& Wu, H.: A review of the genus Pelenomus Thomson (Coleoptera: Curculionidae: Ceutorhynchinae) from China. Zootaxa 3652(4): 401-423.

Yang N., Zhang R.-Zh. \& Ren L. 2013: Two new species of Xenysmoderodes from China (Coleoptera: Curculionidae: Ceutorhynchinae). Zootaxa 3620(4): 533-543.

p. 673, add reference:

Zaslavskij V.A. 1980: [new taxon]. In: Bajtenov M.S. Novye vidy zhukov-dolgonosikov (Coleoptera,
Curculionidae) iz Sredney Azii i Kazakhstana. Trudy Instituta Zoologii Akademii Nauk Kazakhskoy SSR, Seriya Zoologicheskaya 39: 123-130.

p. 674, add reference:

Zimmerman E.C. 1994: Australian Weevils (Coleoptera: Curculionoidea). Vol. 1. Orthoceri, Anthribidae to Attelabidae, The Primitive Weevils. CSIRO Publications - Entomological Society of America, Melbourne, xxxii +741 pp.

p. 680 , add Barynotus Germar, 1817 p. 284 to the right column [Caldara]

p. 686 , add Herpisticus Germar, 1824 p. 394 to the right column

p. 687 , add Hypomeces Schoenherr, 1823 p. 395 to the left column

\section{Acknowledgements}

The authors wish to thank warmly all the colleagues and friends who supported them during the making of this article with literature, suggestions and advice. They are too many to list them and we are afraid of missing someone. The authors are also very deeply grateful to two very special reviewers, Patrice Bouchard (Canadian National Collection of Insects, Ottawa) and Christopher H.C. Lyal (Natural History Museum, London) who greatly improved these pages with their wide knowledge of Coleoptera.

\section{References}

Abbazzi, P. \& Maggini, L., 2009. Elenco sistematicofaunistico dei Curculionoidea italiani, Scolytidae e Platypodidae esclusi (Insecta, Coleoptera). Aldrovandia, 5: 29-216.

Abbazzi, P., Colonnelli E., Masutti, L. \& Osella, G., 1995. Coleoptera Polyphaga XVI (Curculionoidea). In: A. Minelli, S. Ruffo \& S. La Posta (Eds.). Checklist delle specie della fauna italiana. 61. Calderini. Bologna. 68 pp.

Abbazzi, P. \& Osella, G., 1992. Elenco sistematicofaunistico degli Anthribidae, Rhinomaceridae, Attelabidae, Apionidae, Brentidae, Curculionidae italiani (Insecta, Coleoptera, Curculionoidea). I Parte. Redia, 75: 267-414.

Alonso-Zarazaga, M. A., 1990. Revision of the supraspecific taxa in the Palaearctic Apionidae Schoenherr, 1823 (Coleoptera, Curculionoidea). 2. Subfamily Apioninae Schoenherr, 1823: introduction, keys and descriptions. Graellsia, 46: 19-156.

Alonso-Zarazaga, M. A., 2002. Lista preliminar de los Coleoptera Curculionoidea del área ibero-balear, con descripción de Melicius gen. nov. y nuevas citas. Boletín SEA, 31: 9-33.

Alonso-Zarazaga, M. A., 2008. The types of Palaearctic species of the families Apionidae, Rhynchitidae, Attelabidae and Curculionidae in the collection of Étienne Louis Geoffroy (Coleoptera, Curculionoidea). Graellsia, 64(1): 17-44. http://dx.doi.org/10.3989/ graellsia.2008.v64.i1.52

Alonso-Zarazaga, M. A., 2011a. Rhynchitidae. In: I. Löbl \& A. Smetana (Eds.). Catalogue of Palaearctic Coleoptera. Vol. 7. Apollo Books. Stenstrup: 66-73, 109-129. 
Alonso-Zarazaga, M. A., 2011b. Apionidae. In: I. Löbl \& A. Smetana (eds.). Catalogue of Palaearctic Coleoptera. Vol. 7. Apollo Books. Stenstrup: 77-83, 148-176.

Alonso-Zarazaga, M. A., 2014. On the identity of some weevil species described by Johann Christian Fabricius (1745-1808) in the Museum of Zoology of Copenhagen (Coleoptera, Cucujoidea, Curculionoidea, Tenebrionoidea). ZooKeys, 451: 61-91. http://dx.doi. org/10.3897/zookeys.451.8462

Alonso-Zarazaga, M. A., Caldara, R. \& Winkelmann, H., 2013. On the systematic position of some overlooked weevil taxa described by Schrank in 1798 and by Gravenhorst in 1807 (Coleoptera, Curculionidae). Giornale italiano di Entomologia, 13(58): 341-350.

Alonso-Zarazaga, M. A. \& Lyal, C.H.C., 1999. A world catalogue of families and genera of Curculionoidea (Insecta: Coleoptera) (excepting Scolytidae and Platypodidae). Entomopraxis. Barcelona. 315 pp.

Alonso-Zarazaga, M. A., Sánchez-Ruiz, M. \& DomingoQuero, T., 2006. Lista preliminar de los Curculionoidea (Coleoptera) de la Comunidad de Madrid (España). Graellsia, 62(extra): 43-52. http://dx.doi.org/10.3989/ graellsia.2006.v62.iExtra.111

Alziar, G., 2015. Observations chorologiques et biologiques sur quelques Curculionides (Coleoptera, Curculionoidea) du sud-ouest de l'Europe. Biocosme mésogéen, 32(1-2): 3-21.

Antonie, I., 2007. Systematischer Katalog der bisher in Rumänien verzeichneten Rhynchitidae und Attelabidae (Coleoptera: Curculionoidea). Entomologica Romanica, 12: 61-76.

Avgin, S. S. \& Colonnelli, E., 2011. Curculionoidea (Coleoptera) from southern Turkey. African Journal of Biotechnology, 10(62): 13555-13597.

Bedel, L., 1913. Le genre Rhynchites Schneider (Col. Curculionidae) dans le Nord de l'Afrique. Bulletin de la Société entomologique de France 1913(8): 189-191.

Benedikt, S., Borovec, R., Fremuth, J., Krátky, J., Schön, K., Skuhrovec, J. \& Trýzna, M., 2010. Komentovaný seznam nosatcovitých brouků (Coleoptera: Curculionoidea bez Scolytinae a Platypodinae) České republiky a Slovenska 1. díl. Systematika, faunistika, historie výzkumu nosatcovitých brouků v České republice a na Slovensku, nástin skladby, seznam. Komentáře k Anthribidae, Rhynchitidae, Attelabidae, Nanophyidae, Brachyceridae, Dryophthoridae, Erirhinidae a Curculionidae: Curculioninae, Bagoinae, Baridinae, Ceutorhynchinae, Conoderinae, Hyperinae / Annotated checklist of weevils (Coleoptera: Curculionoidea excepting Scolytinae and Platypodinae) of the Czech Republic and Slovakia Part 1. Systematics, faunistics, history of research on weevils in the Czech Republic and Slovakia, structure outline, checklist. Comments on Anthribidae, Rhynchitidae, Attelabidae, Nanophyidae, Brachyceridae, Dryophthoridae, Erirhinidae and Curculionidae: Curculioninae, Bagoinae, Baridinae, Ceutorhynchinae, Conoderinae, Hyperinae. Klapalekiana, 46: 1-363.

Bertram, M. \& Jourdheuil, P., 1968. Bases écologiques de la lutte contre les apions seminivores du trèfle violet Trifolium pratense L. Annales des Épiphyties, 19(2): 335-365.
Borovec, R., Meregalli, M. \& Alonso-Zarazaga, M.A., 2003. New genus, new subgenus and new records of Curculionidae for the Iberian fauna (Coleoptera). Boletín S.E.A., 33: 69-71.

Boselli, F., 1928. Elenco delle specie d'insetti dannosi e loro parassiti ricordati in Italia, dal 1911 al 1925. Laboratorio di Entomologia Agraria, Reale Instituto Superiore Agrario. Portici. 264 pp.

Bouchard, P., Bousquet, Y., Davies, A. E., AlonsoZarazaga, M. A,, Lawrence, J. F., Lyal, C. H. C., Newton, A. F., Reid, C. A. M., Schmitt, M., Ślipiński, S. A. \& Smith, A. B. T., 2011. Family-group names in Coleoptera (Insecta). ZooKeys, 88: 1-972. http://dx.doi. org/10.3897/zookeys.88.807

Boukli Hacene, S., Hassaine, K. \& Ponel, P., 2011. Les peuplements des coléoptères du marais salé de l'embouchure de la Tafna (Algérie). Revue d'Écologie (Terre Vie), 66: 1-15.

Braunert, C., 2009. Verzeichnis der Rüsselkäfer Luxemburgs (Coleoptera, Curculionoidea) mit Ausnahme der Borkenkäfer (Scolytinae) und Kernkäfer (Platypodinae). Bulletin de la Société des naturalistes luxembourgeois, 110: 125-142.

Caldara, R., 2008. On the taxonomy and nomenclature of some Mecinini (Coleoptera, Curculionidae). Fragmenta Entomologica, 40(1): 125-137. http://dx.doi.org/ $10.4081 /$ fe. 2008.111

Caldara, R., 2013. Curculionidae: Curculioninae. In: I. Löbl \& A. Smetana (eds.). Catalogue of Palaearctic Coleoptera. Vol. 8. Brill. Leiden: 51-56, 117-172.

Caldara, R., Colonnelli, E. \& Alonso-Zarazaga, M. A., 2014. On the availability of the name Curculio primitus Herbst, 1795 (Coleoptera, Curculionidae). Bollettino del Museo Civico di Storia Naturale di Verona, 38, Botanica Zoologia: 133-134.

Caldara, R. \& Fogato, V., 2013. Systematics of the weevil genus Mecinus Germar, 1821 (Coleoptera: Curculionidae). I. Taxonomic treatment of the species. Zootaxa, 3654: 1-105. http://dx.doi.org/10.11646/ zootaxa.3654.1.1

Caldara, R., Franz, N. \& Oberprieler, R., 2014. 3.7.10. Curculioninae Latreille, 1802. In: R.A.B. Leschen \& R.G. Beutel (eds.). Coleoptera, Beetles. Volume 3: Morphology and Systematics (Phytophaga). Handbook of Zoology: Arthropoda: Insecta. De Gruyter. Berlin/Boston: 589-628.

Caldara, R., Pesarini, C., Colonnelli, E. \& Baviera, C., 2010. V Contributo alla revisione della collezione coleotterologica Francesco Vitale: Coleoptera Curculionoidea (Prima parte). Memorie della Società entomologica italiana, 89: 229-257. http://dx.doi.org/10.4081/ memorieSEI.2010.229

Carpaneto, G. M., Mazziotta, A. \& Vigna Taglianti, A., 2006. Ricerche preliminari sui Coleotteri. In: C. Battisti (ed.). Biodiversità, gestione e conservazione di un'area umida del litorale tirrenico: la Palude di Torre Flavia. Gangemi Editore. Roma: 205-214.

Champion, G. C. \& Chapman, T. A., 1904. An entomological excursion to Moncayo, N. Spain, by George Charles Champion, F.Z.S.; with some remarks on the habits of Xyleborus dispar, Fabr., by Dr. Thomas Algernon 
Chapman, M.D., F.Z.S. Transactions of the Entomological Society of London, 1904(1): 81-102, pl. XV-XVI.

Cholewicka, K., 1981. Curculionids (Coleoptera, Curculionidae) of Warsaw and Mazovia. Memorabilia Zoologica, 34: 235-260.

Cholewicka-Wiśniewska, K., 1994. The structure of weevil communities (Coleoptera, Curculionidae) of selected Polish pine forests. Fragmenta Faunistica (Warszawa), 36: 397-439.

Colonnelli, E., 2003. A revised checklist of Italian Curculionoidea (Coleoptera). Zootaxa, 337: 1-142.

Craveri, C., 1926. Insetti nocivi all'Agricoltura ed alla Selvicoltura. Descrizione - Costumi e mezzi per combatterli. Seconda edizione riveduta con 229 figure. Ulrico Hoepli. Milano. xii +490 pp.

Cunev, J., 2013. Nové a zaujímavé nálezy chrobákov (Coleoptera) nadčel'ade Curculionoidea na území Slovenska. Entomofauna carpathica, 25(2): 1-14.

Cunev, J. \& Majzlan, O., 1998. Ekosozologické vyhodnotenie fauny chrobákov (Coleoptera) pr Vel'ký vrch v katastri Malé Kršteňany. Folia faunistica Slovaca, 3: 81-96.

Deakin, R., 2009. Wildwood A journey through trees. Free Press. New York, London, Toronto, Sidney. 416 pp.

Dedûhin, S.V., 2012. Dolgonosikoobraznye žestkokrylye (Coleoptera, Curculionoidea) Bâtsko-Kamskogo meždureč'â: fauna, rasprostranenie, èkologiâ: monografiâ. Izd-vo Udmurtskij universitet. Iževsk. 340 pp.

Dieckmann, L., 1988. Beiträge zur Insektenfauna der DDR: Curculionidae (Curculioninae: Ellescini, Acalyptini, Tychiini, Anthonomini, Curculionini). Beiträge zur Entomologie, 38: 365-468.

Dipauli, A. v., 1834. Biographische Nachrichten von dem Naturforscher Laicharding. Beiträge zur Geschichte, Statistik, Naturkunde und Kunst von Tirol und Vorarlberg (Z. Ferdinandeum), 8: 186-224.

Ehret, J. M., 1986. Les relations entre Apions (Coléoptères Curculionidae, Apioninae) et les groupements végétaux. Bulletin de la Société d'Histoire naturelle d'Autun, 119: 31-37.

Ehret, J. M., 1989. Les Apions de l'Ardèche (Coleoptera Curculionidae Apioninae). Bulletin mensuel de la Société linnéenne de Lyon, 58(8): 246-250.

Ehret, J. M., 1991. Connaissance des collections regionales. Les Apions de la Collection J. Barbier. Muséum d'Histoire Naturelle de Dijon, France (Coleoptera Curculionidae, Apioninae). Bulletin de la Société d'Histoire naturelle d'Autun, 134 [1990]: 9-24.

Ehret, J. M., 1994. Sur quelques insectes (Coléoptères Curculionidae Apioninae) autunois. Bulletin de la Société d'Histoire naturelle d'Autun, 148: 5-26.

El-Mergawy, R. A. A. M., Al Ajlan, A. M., Abdalla, N., Nasr, M. I. \& Silvain, J. F., 2011. Genetic comparison among Rhynchophorus ferrugineus and four Rhynchophorus species. Journal of Agricultural Science and Technology B, 1: 610-615.

El-Retail, A., Hiepe, T., Nickel, S. \& Ribbeck, R., 1973. New potential intermediate hosts for the tapeworm Hymenolepis nana Siebold, 1853. Acta Parasitologica Polonica, 21(15): 263-268.
Evenhuis, N. L., 1997. Litteratura taxonomica dipterorum (1758-1930). 2 vols. Backhuys Publishers. Leiden. vii +871 pp.

Evenhuis, N. L., 2014. Dates of the Leipzig Book Fairs (1758-1860), with notes on the book catalogs. Sherbornia, 1(1): 1-4.

Germann, C., 2010. Die Rüsselkäfer (Coleoptera, Curculionoidea) der Schweiz. Checkliste mit Verbreitungsangaben nach biogeografischen Regionen. Mitteilungen der Schweizerischen Entomologischen Gesellschaft, 83: 41-118.

Ghahari, H. \& Colonnelli, E., 2012. Curculionoidea from Golestan province, Northern Iran (Coleoptera). Fragmenta entomologica, 44(1): 101-161. http://dx.doi.org/ $10.4081 /$ fe. 2012.37

Giusto, C., 2011. Aspidapion motschulskyi (Hochhuth) removed from synonymy with $A$. aeneum (Fabricius) (Coleoptera: Apionidae). Koleopterologische Rundschau, 81: 291-304.

Giusto, C., 2012: In: P. E. Stüben, P. Sprick, L. Behne, G. Alziar, E. Colonnelli, C. Giusto, J. Messutat \& L. A. Teodor. The Curculionoidea (Coleoptera) of Cyprus. Results of a collecting journey on Cyprus by members of the CURCULIO Institute in April 2010. Snudebiller, 13: 79-137.

Gønget, H., 1997. The Brentidae (Coleoptera) of northern Europe. Fauna Entomologica Scandinavica, 34: 1-289 .

Gültekin, L., 2013. A new record billbug, Sphenophorus abbreviatus (F.) (Coleoptera: Curculionoidea: Dryophthoridae) from Turkey. Journal of the Entomological Research Society, 15(3): 37-40.

Heijerman, T., 1993. Naamlijst van de snuitkevers van Nederland en het omliggende gebied (Curculionoidea: Curculionidae, Apionidae, Attelabidae, Urodontidae, Anthribidae en Nemonychidae). Nederlandse Faunistische Mededelingen, 5:19-46.

International Commission on Zoological Nomenclature, 1989. Opinion 1529. Ceutorhynchus Germar, 1824, Rhinoncus Schoenherr, 1825 and Curculio assimilis Paykull, 1792 (Insecta, Diptera [sic!]): conserved, and Curculio assimilis Paykull, 1792 and Curculio pericarpius Linnaeus, 1758 designated as the type species of Ceutorhynchus and Rhinoncus respectively. Bulletin of Zoological Nomenclature, 46(1): 71-73.

Kirchner, O., 1906. Die Krankheiten und Beschädigungen unserer landwirtschaftlichen Kulturpflanzen. Eine Anleitung zu ihrer Erkennung und Bekämpfung für Landwirte, Gärtner u. a. 2. vollständig umgearbeitete Auflage. Verlagschbuchhandlung Eugen Ulmer. Stuttgart. VIII +675 pp.

Kittel, G., 1883. Systematische Uebersicht der Käfer, welche in Baiern und der nächsten Umgebung vorkommen. (Fortsetzung). Correspondenz-Blatt des naturwissenschaftlichen Vereines in Regensburg, 37(3-4): 35-57.

Kloet, G. S. \& Hincks, W. D., 1977. A check list of British insects, Part 3: Coleoptera and Strepsiptera, revised by R.D. Pope. The Royal Entomological Society. London. xiv $+105 \mathrm{pp}$.

Knutelski, S., 2005. Różnorodność, ekologia i chorologia ryjkowców rezerwatu biosfery" Tatry" (Coleoptera: Curculionoidea). Monografie Faunistyczne, 23: 1-340. 
Knutelski, S. \& Knutelska, E., 2014. Chrząszcze Pienin w zbiorach Pienińskiego Parku Narodowego oraz obecny stan poznania tej fauny (Insecta: Coleoptera). Pieniny Przyroda i Człowiek, 13: 45-62.

Kolař́k, P. \& Rotrekl, J., 2013. Regulation of the abundance of clover seed weevils, Apion spp. (Coleoptera: Curculionidae) in a seed stand of red clover (Trifolium pratense L.). Journal of Entomological and Acarological Research, 45: e19: 106-109.

Legakis, A., 1990. The Zoological Museum of the University of Athens. 4. The collection of Coleoptera from Greece. Part II. Biologia Gallo-hellenica, 17(1): 59-96.

Léon-Hilaire, Q., 1924. Contribution à la Faune Entomologique de la Catalogne. Notes de chasse sur les Coléoptères du Val d'Aran. Butlletí de la Institució Catalana d'Història Natural, 24(2-3): 64-81.

Lesne, P., 1908. Sur la nomenclature de divers Insectes de l'Olivier. Bulletin de la Société entomologique de France, 1908(2): 29-31.

Lona, C., 1938. Curculionidae: Otiorrhynchinae III. Pars 162. In: S. Schenkling (ed.). Coleopterorum Catalogus auspiciis et auxilio W. Junk. W. Junk. 's-Gravenhage: 415-600.

Lindelow, A. \& Björkman, C., 2001. Insects on lodgepole pine in Sweden - current knowledge and potential risks. Forest Ecology and Management, 141: 107-116. http:// dx.doi.org/10.1016/S0378-1127(00)00494-1

Lohse, G.A., 1981. 93. Familie: Curculionidae. 5. Unterfamilie: Apioninae. In: H. Freude, K.W. Harde \& G.A. Lohse (eds.). Die Käfer Mitteleuropas. Band 10. Bruchidae, Anthribidae, Scolytidae, Platypodidae, Curculionidae. Goecke \& Evers. Krefeld: 127-183.

Lyal, C. H. C., 2011. Dryophthoridae. In: I. Löbl \& A. Smetana (eds.). Catalogue of Palaearctic Coleoptera. Vol. 7. Apollo Books. Steenstrup: 185-192.

Majzlan, O., 2014. Chrobáky (Coleoptera) dvoch lokalít Závod- Šišuláky a Gajary na Záhorí. Entomofauna carpathica, 26(2): 12-62.

Majzlan, O. \& Majzlan, J., 2011. Sociony chrobákov (Coleoptera) na halde lúženca z niklovej huti v Seredi. Naturae Tutela, 15/1: 27-37.

Mazur, M., 2003. Ryjkowce (Coleoptera: Nemonychidae, Attelabidae, Apionidae, Curculionidae) siedlisk kserotermicznych Polski. II. Szczepanowice koło Miechowa. Wiadomosci Entomologiczne, 22(3): 143-150.

Mifsud, D. \& Colonnelli, E., 2010. The Curculionoidea of the Maltese Islands (Central Mediterranean) (Coleoptera). Bulletin of the Entomological Society of Malta, 3: 55-143.

Millin, A.L., 1795. Rapport fait à la Société d'Histoire Naturelle, sur le Calendrier Entomologique de M. Giorna. Magasin Encyclopédique, ou Journal des Sciences, des Lettres et des Arts, 2: 311-319.

Modarres Awal, M. \& Hossein Pour, F., 2010. A contribution to the snout beetles fauna of Khorasan province in Iran (Coleoptera: Curculionidae). Munis Entomology \& Zoology, 5 (2): 623-626.

Morris, M. G., 2003. An annotated check list of British Curculionoidea (Col.). Entomologist's Monthly Magazine, 139: 193-225.
Moulin, J. \& Viallier, J., 1989. Coléoptères de la région de Roussillon (Isère ). IV - Curculionidae. Bulletin mensuel de la Société linnéenne de Lyon, 58(6): 182-197.

Mukhtarova, G.M. \& Abdurakhmanov, G.M., 2015. Vidovoj sostav i ekologo-zoogeografičeskij analiz žukovdolgonosikov vnutrennego Gornogo Dagestana. Ekologiâ životnyh Ûg Rossii: ekologiâ, razvitie, 10(1): 67-103.

Nyholm, T., 1950. Zur Kenntnis der Curculionidenfauna Schwedens. 2. Apion interjectum Desbr., eine von aestivum Germ. gut getrennte Art, in Schweden aufgefunden. Entomologisk Tidskrift, 71: 179-193.

Offer, D., Edwards, M. \& Edgar, P., 2003. Grazing Heathland: A guide to impact assessment for insects and reptiles. English Nature Research Reports, 497: 1-88.

Papp, J., 2000. First synopsis of the species of obscurator species-group, genus Bracon, subgenus Glabrobracon (Hymenoptera: Braconidae, Braconinae). Annales Historico-Naturales Musei Nationalis Hungarici, 92: 229-264.

Papp, J., 2012. A revision of the Bracon Fabricius species in Wesmael's collection deposited in Brussels (Hymenoptera: Braconidae: Braconinae). European Journal of Taxonomy, 21: 1-154. http://dx.doi.org/10.5852/ejt. 2012.21

Pelletier, J., 2005. Catalogue de Curculionoidea de France (Coleoptera). Biocosme Mésogéen, 21 [2004]: 75-147.

Pelletier, J., 2014. Apionidae Schoenherr, 1823. In: M. Tronquet (coord.). Catalogue des Coléoptères de France. Association Roussillonnaise d'Entomologie. Perpignan: 636-645.

Pierce, W. D., 1918. A manual of dangerous insects likely to be introduced in the United States through importations. U.S. Department of Agriculture, Office of the Secretary. Washington. 256 pp., 49 pl.

Pirotta, P.R., 1879. Libellulidi Italiani. Annali del Museo Civico di Storia Naturale di Genova, 14: 401-489.

Podlussány, A., 2001. Somogy megye ormányosalkatú bogarainak katalógusa (Coleoptera: Curculionoidea). Natura Somogyensis, 1: 237-252.

Podlussány, A. \& György, Z., 2008. A Mátra Múzeum bogárgyûjteménye. Coleoptera: Curculionoidea: Anthribidae, Apionidae, Attelabidae, Curculionidae, Nanophyidae, Rhynchitidae, Scolytidae, Urodontidae. Folia Historico Naturalia Musei Matraensis, 32: 183-200.

Poiras, A. A., 1998. Catalogue of the weevils (Coleoptera, Curculionoidea) and their host plants in the Republic of Moldova. Pensoft Publishers. Sofia-Moscow. $156 \mathrm{pp}$.

Pywell, R.F., James, K.L., Herbert, I., Meek, W.R., Carvell, C., Bell, D. \& Sparks, T.H., 2005. Determinants of overwintering habitat quality for beetles and spiders on arable farmland. Biological Conservation, 123: 79-90. http://dx.doi.org/10.1016/j.biocon.2004.10.010

Rheinheimer, J. \& Hassler, M., 2010. Die Rüsselkäfer Baden-Württembergs. Engelhardt \& Bauer. Karlsruhe. 944 pp.

Russo, G., 1932. Contributo alla conoscenza degli scolitidi. III. Ilesinini dell'Olivo. Bollettino del Laboratorio di Zoologia in Portici, 26: 89-114.

Schaum, H., 1847. Bemerkungen über Fabricische Käfer. Stettiner Entomologische Zeitung, 8(2): 39-57. 
Schmidt, M. H., Lefebvre, G., Poulin, B. \& Tscharntke, T., 2005. Reed cutting affects arthropod communities, potentially reducing food for passerine birds. Biological Conservation, 121: 157-166. http://dx.doi.org/10.1016/j. biocon.2004.03.032

Schott, C., 1999. Catalogue des coléoptères d'Alsace, vol. 10. Curculionidae 1. Société Alsacienne d'Entomologie. Strasbourg. $145 \mathrm{pp}$.

Schrank, F. P., 1782. Kritische Revision des österreichischen Insectenverzeichnisses. Neues Magazin für die Liebhaber der Entomologie, 1(2): 135-168.

Silfverberg, H., 1979. Enumeratio Coleopterorum Fennoscandiae et Daniae. Entomologiska Bytesförening. Helsingfors. $79 \mathrm{pp}$.

Simpson, T., 2001. The Roman well at Piddington, Northamptonshire, England: an investigation of the Coleopterous Fauna. Environmental Archaeology, 6(1): 91-96. http://dx.doi.org/10.1179/env.2001.6.1.91

Skuhrovec, J. 2013. Hyperinae. In: I. Löbl \& A. Smetana (eds.). Catalogue of Palaearctic Coleoptera, Vol. 8. Brill. Leiden: 93-96.

Syrett, P., Fowler, S. V., Coombs, E. M., Hosking, J. R., Markin, G. P., Paynter, Q. E. \& Sheppard, A. W., 1999. The potential for biological control of Scotch broom (Cytisus scoparius) (Fabaceae) and related weedy species. Biocontrol News and Information, 20(1): 17N-34N.

Telnov, D., 2004. Compendium of Latvian Coleoptera. Check-list of Latvian beetles (Insecta Coleoptera). Entomological Society of Latvia. Riga. 115 pp.

Tempère, G. \& Péricart, J., 1989. Coléoptères Curculionidae. Quatrième partie. Compléments aux trois volumes d'Adolphe Hoffmann. Corrections, additions et répertoire. Faune de France Vol. 74. Fédération Française des Sociétés de Sciences Naturelles. Paris. 534 pp.

Tracy, J. L. \& DeLoach, C. J., 1998. Suitability of classical biological control for giant reed (Arundo donax) in the United States. In: C.E. Bell (ed.). Arundo and Saltcedar Management Workshop Proceedings, Ontario: 73-109.
Ugarte, I. \& Alonso-Zarazaga, M. A., 2002. Catálogo bibliográfico de los Curculionoidea (Coleoptera) del País Vasco (exc. Scolytidae y Platypodidae). Naturzale, 17: 253-264.

Wanat, M., 1994. Ryjkowce (Coleoptera: Curculionoidea: Anthribidae, Rhinomaceridae, Rhynchitidae, Attelabidae, Apionidae, Curculionidae) Puszczy Białowieskiej. Polskie Pismo Entomologiczne, 63: 37-112.

Wanat, M., 2004. Zjawisko rójki u Sphenophorus striatopunctatus (Goeze, 1777) i Notaris granulipennis Tournier, 1874 (Coleoptera: Curculionidae). Wiadomości entomologiczne, 23(1): 35-38.

Wanat, M. \& Mokrzycki, T., 2005. A new checklist of the weevils of Poland (Coleoptera: Curculionoidea). Genus, 16: 69-117.

Webb, J. R., Drewitt, A. L. \& Measures, G. H., 2010. Managing for species: Integrating the needs of England's priority species into habitat management. Part 1 Report. Natural England Research Reports, 024: 1-129.

Wellhouse, W. H., 1922. The insect fauna of the genus Crataegus. Cornell University Agricultural Experiment Station Memoir, 56: 1041-1136.

Wiech, K. \& Wnuk, A., 1990. Obserwacje nad składem gatunkowym ryjkowców (Col., Curculionidae) na koniczynie czerwonej (Trifolium pratense L.). Acta Agraria et Silvestria, Series Silvestris, 29: 73-82.

Wood, S. L. \& Bright, D. E., Jr., 1992. A Catalog of Scolytidae and Platypodidae (Coleoptera), Part 2: Taxonomic Index. Great Basin Naturalist Memoirs, 13(A): [2, Contents]+1-834; (B): [2, Contents] +835-1553.

Ximénez de Embún y González-Arnao, J., 1962. Los montes. Introducción a la selvicultura. Segunda edición ampliada y actualizada. Manuales Técnicos, Serie E, $\mathrm{n}^{\circ}$ 14. Ministerio de Agricultura. Madrid: xii +399 pp.

Yunakov, N. N., 2013. Curculionidae: Entiminae: Alophini, Blosirini [sic!], Cyphicerini, Polydrusini. In: I. Löbl \& A. Smetana (eds.). Catalogue of Palaearctic Coleoptera. Vol. 8. Brill. Leiden: 64-66. 